SAND83-1798

Distribution

Unlimited Release

Category UC -70

Printed September 1985

\title{
Regional Well-Log Correlation in the New Mexico Portion of the Delaware Basin
}

\author{
David J. Borns \\ Sue-Ellen Shaffer \\ Earth Sciences Division \\ Sandia National Laboratories \\ Albuquerque, NM 87185
}

\begin{abstract}
Although well logs provide the most complete record of stratigraphy and structure in the northern Delaware Basin, regional interpretations of these logs generate problems of ambiguous lithologic signatures and one-hole anomalies. Interpretation must therefore be based on log-to-log correlation rather than on inferences from single logs. In this report, logs from 276 wells were used to make stratigraphic picks of Ochoan horizons (the Rustler, Salado, and Castile Formations) in the New Mexico portion of the Delaware Basin. Current log correlation suggests that: (1) the Castile is characterized by lateral thickening and thinning; (2) some Castile thinnings are of Permian age; (3) irregular topography in the Guadalupian Bell Canyon Formation may produce apparent structures in the overlying Ochoan units; and (4) extensive dissolution of the Salado is not apparent in the area of the Waste Isolation Pilot Project (WIPP) site.
\end{abstract}

This exument is

PUELICLY

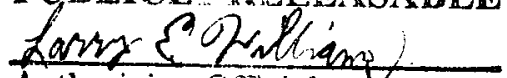

Authorizing Oficial

Date: $02 / 15 / 2006$

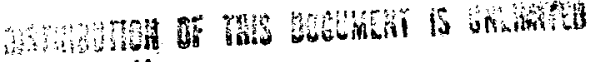
.. -

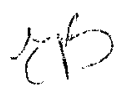




\section{DISCLAIMER}

This report was prepared as an account of work sponsored by an agency of the United States Government. Neither the United States Government nor any agency Thereof, nor any of their employees, makes any warranty, express or implied, or assumes any legal liability or responsibility for the accuracy, completeness, or usefulness of any information, apparatus, product, or process disclosed, or represents that its use would not infringe privately owned rights. Reference herein to any specific commercial product, process, or service by trade name, trademark, manufacturer, or otherwise does not necessarily constitute or imply its endorsement, recommendation, or favoring by the United States Government or any agency thereof. The views and opinions of authors expressed herein do not necessarily state or reflect those of the United States Government or any agency thereof. 


\section{DISCLAIMER}

Portions of this document may be illegible in electronic image products. Images are produced from the best available original document. 


\section{Acknowledgment}

Well-log picks were initially made by a team consisting of Steven J. Lambert, Terri Ortiz, and the authors. The Applicon data base was set up by Bruce Whittet and Robert Williams. Meredith Edwards assisted greatly in preparing the final graphics.

\section{DISCLAIMER}

This report was prepared as an account of work sponsored by an agency of the United States . Government. Neither the United States Government nor any agency thereof, nor any of their employees, makes any warranty, express or implied, or assumes any legal liability or responsibility for the accuracy, completeness, or usefulness of any information, apparatus, product, or process disclosed, or represents that its use would not infringe privately owned rights. Reference herein to any specific commercial product, process, or service by trade name, trademark, manufacturer, or otherwise does not necessarily constitute or imply its endorsement, recommendation, or favoring by the United States Government or any agency thereof. The views and opinions of authors expressed herein do not necessarily state or reflect those of the United States Government or any agency thereof. 


\section{Contents}

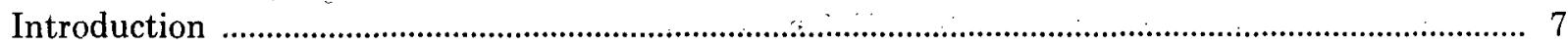

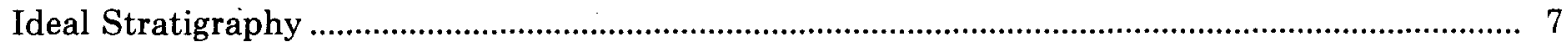

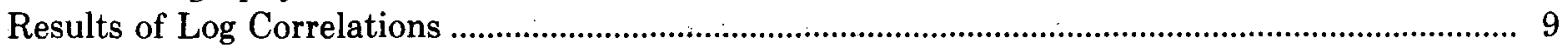

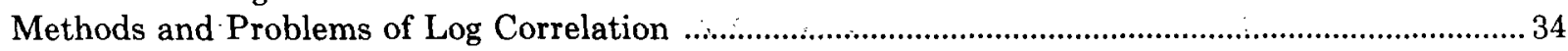

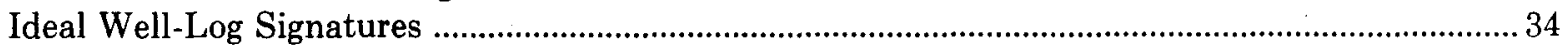

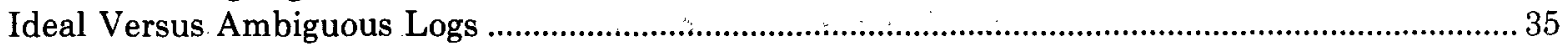

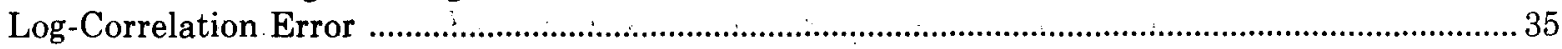

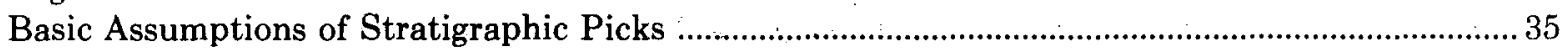

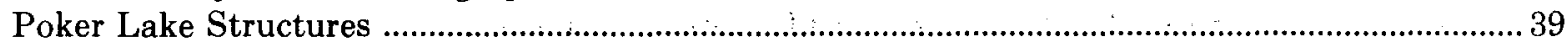

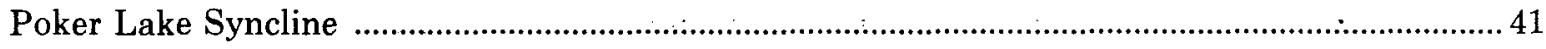

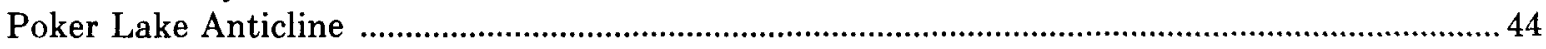

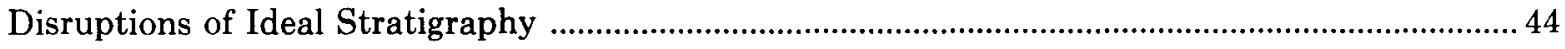

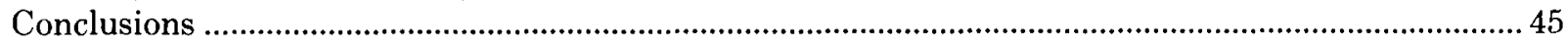

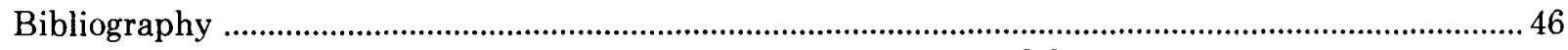

APPENDIX_-Well-Log Data Arranged by Township, Range, and Section ........................................ 47

\section{Figures}

1 Well Location and Applicon identifiers (AIDs) ........................................................................... 8

2 Idealized cross section, Northern Delaware Basin ....................................................................... 9

3 Contour map: Top of the Rustler …...................................................................................... 10

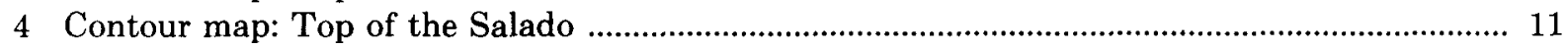

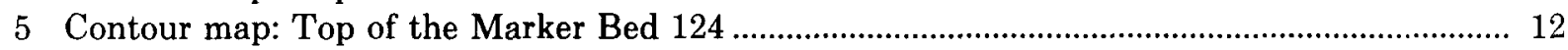

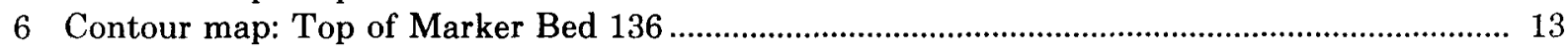

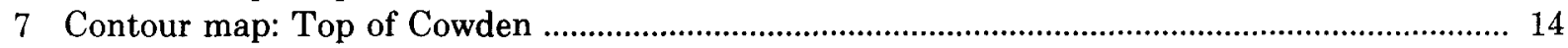

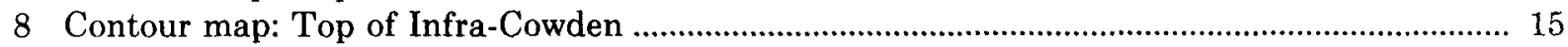

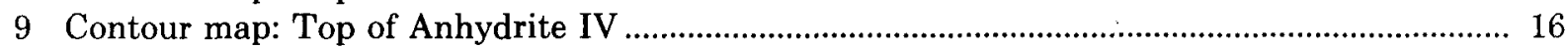

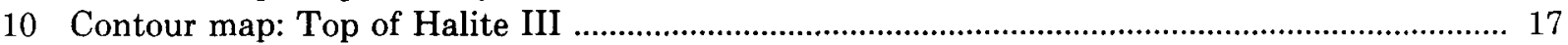

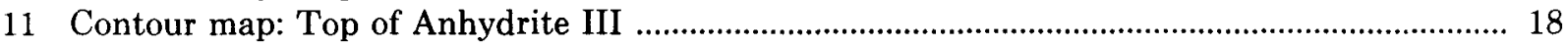

12 Contour map: Top of Halite II .......................................................................................... 19

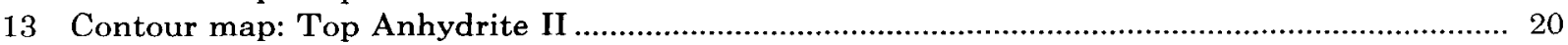

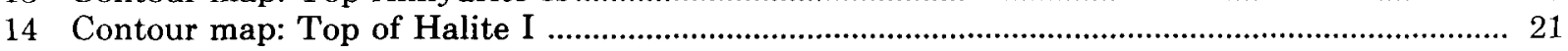

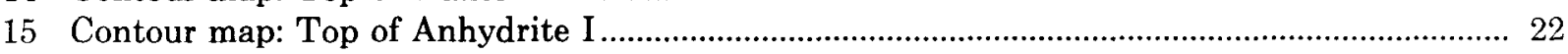

16 Contour map: Top of Delaware Mountain Group .................................................................... 23

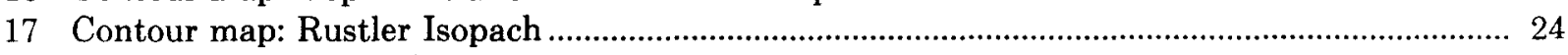

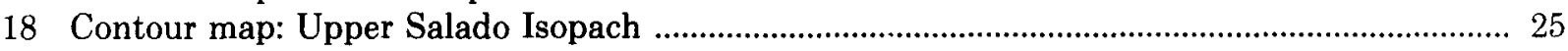

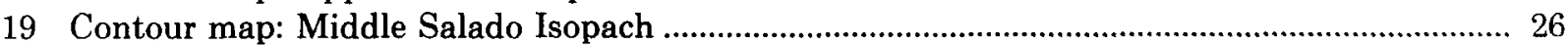

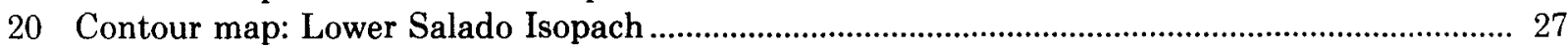

21 Contour map: Marker Bed 136 to Halite II Isopach ...................................................................... 28

22 Contour map: Infra-Cowden Isopach ........................................................................................... 29

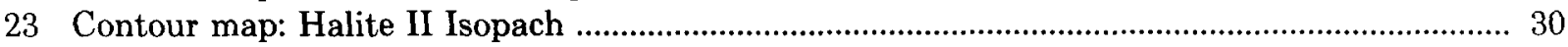

24 Contour map: Halite II to Halite I Isopach ................................................................................ 31

25 Contour map: Halite I Isopach ..................................................................................................... 32

26 Contour map: Halite I to Delaware Mountain Group Isopach ................................................. 33

27 Gamma-ray and acoustilog signatures for ideal well log from which the stratigraphic picks

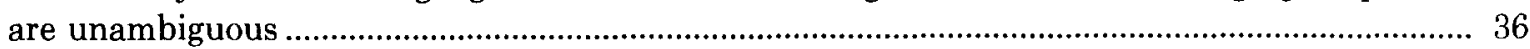




\section{Figures (Cont)}

28 Comparison of ideal and nonideal well logs for the section from the Dewey Lake formation through the Salado Formation

29 Comparison of ideal and nonideal logs of the lower Salado and Castile stratigraphy

38

30 Isopach Map of Halite I in the northern Delaware Basin

31 Poker Lake structures

32 Oblique view of holes in Northwest corner of Figure 31

33 Detail map showing locations of Poker Lake boreholes in Section 8, northwest corner, of Figures 31 and 32

34 Fence diagram along a north-south line through the Poker Lake structure

35 Detail of upper section of massive anhydrite from holes in Poker Lake structures

36 Fence diagram along an east-west line through the Poker Lake structures

37 Idealized effects of (A) Castile-Salado unconformity on acoustilog; and (B) selective halite dissolution in addition to unconformity 


\section{Regional Well-Log Correlation in the New Mexico Portion of the Delaware Basin}

\section{Introduction}

Borehole geophysical logs provide records of stratigraphy and structure in the northern Delaware Basin that are more detailed than previous data obtainable from incomplete coring and poor outcrop. Structural and stratigraphic variations in a bedded evaporite sequence may be caused by sedimentation, deformation, or dissolution. Well logs provide the critical and sometimes only data for inferring which processes were or are active. Interpretations of lateral continuity of structures also come from log correlation.

Well logs from the New Mexico portion of the Delaware Basin were examined for this report (Figure 1 ). The area covered is a $30 \times 36-\mathrm{mi}$ rectangle (T21S to T25S and R29E to R34E). The northern edge of the area lies adjacent to the Capitan Reef. The resulting log correlation in this area provided a data base for previous reports on dissolution and deformation (Lambert, 1983; Borns et al, 1983, respectively) as well as for this current evaluation of earlier log correlations in the region (e.g., Anderson, 1978). In particular, this report addresses the specific problems of onehole anomalies and ambiguity of $\log$ interpretation.

\section{Ideal Stratigraphy}

Powers et al (1978), Snyder (in Borns et al, 1983) and Lambert (1983), discuss the stratigraphy of the northern Delaware Basin in great detail. We briefly review the stratigraphy in this report; the interested reader seeking more information may refer to the references cited.

The strata studied in this report are all of Permian age. The younger Permian formations (the Rustler, Salado, and Castile) are Ochoan, and the Delaware Mountain Group (DMG) is Guadalupian. The Rustler is the uppermost evaporite unit used in this study (see Figure 2). The top of the Rustler is considered to be the top of the first persistent anhydrite bed as penetrated by oil and gas drillings. This anhydrite bed is a clear marker for stratigraphic correlations. The
Rustler contains two major members, the Culebra and Magenta Dolomites, within alternating beds of anhydrite, halite, and siltstone.

The underlying Salado Formation is primarily halite. The formation is here divided into three units: the Upper, Middle, and Lower Salado. The upper and lower boundaries, respectively, of these units are the Salado-Rustler contact and Marker Bed 124 for the Upper Salado; Marker Beds 124 and 136 for the Middle Salado; and Marker Bed 136 and the Salado-Castile contact for the Lower Salado. The Lower Salado includes the Cowden Anhydrite and the Infra-Cowden Halite; the base of the Infra-Cowden is the unconformable Salado-Castile contact (cf Adams, 1944). Marker Beds 124 and 136 are 2 of the 45 numbered siliceous or sulfatic units that are numbered 100 to 145 in the Salado. This usage originated in the local potash industry (Jones et al, 1960). These marker beds are traceable in the subsurface for several kilometers, although they are not recognizable in every hole.

The Castile Formation is composed of alternating anhydrite and halite units (Lambert, 1983). The complete section of the Castile is divided into seven members (in descending order): Anhydrite IV, Halite III, Anhydrite III, Halite II, Anhydrite II, Halite I, and Anhydrite I. The section is not universally complete because of the cross-cutting effects of the SaladoCastile unconformity and lateral facies variations. In some areas within the basin, the anhydrite units are blocky, nodular, or brecciated. Such zones are interpreted to be the result of deep dissolution (Anderson, 1978).

The Bell Canyon Formation is the uppermost unit of the DMG, but it is the lower-most unit of interest in - this report. The Bell Canyon is a thick section of sandstone and siltstone with some shale (King, 1948; Davies, 1983). 


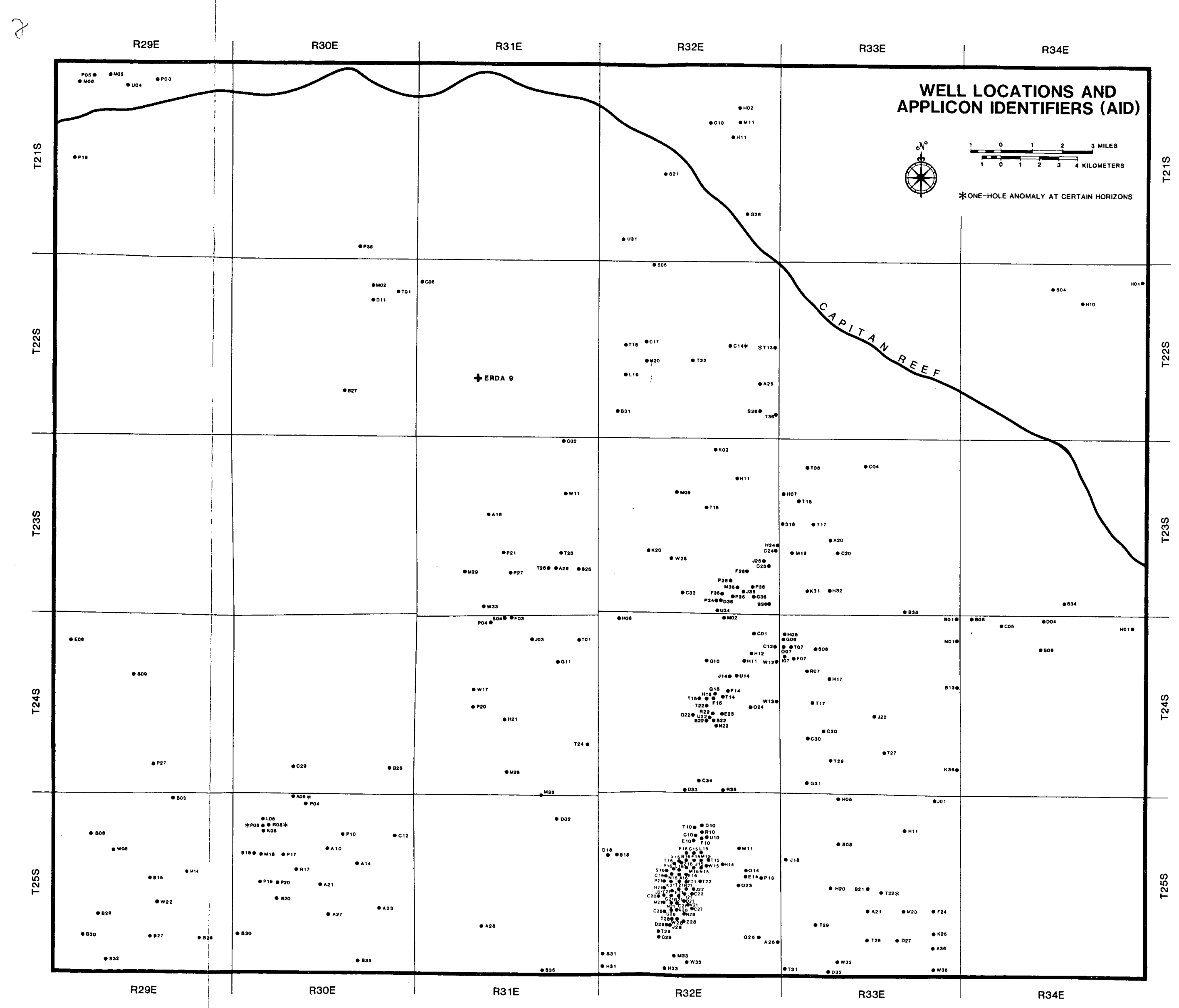

Figure 1. Well location and Applicon identifiers (AIDs) (as discussed in a later section) 


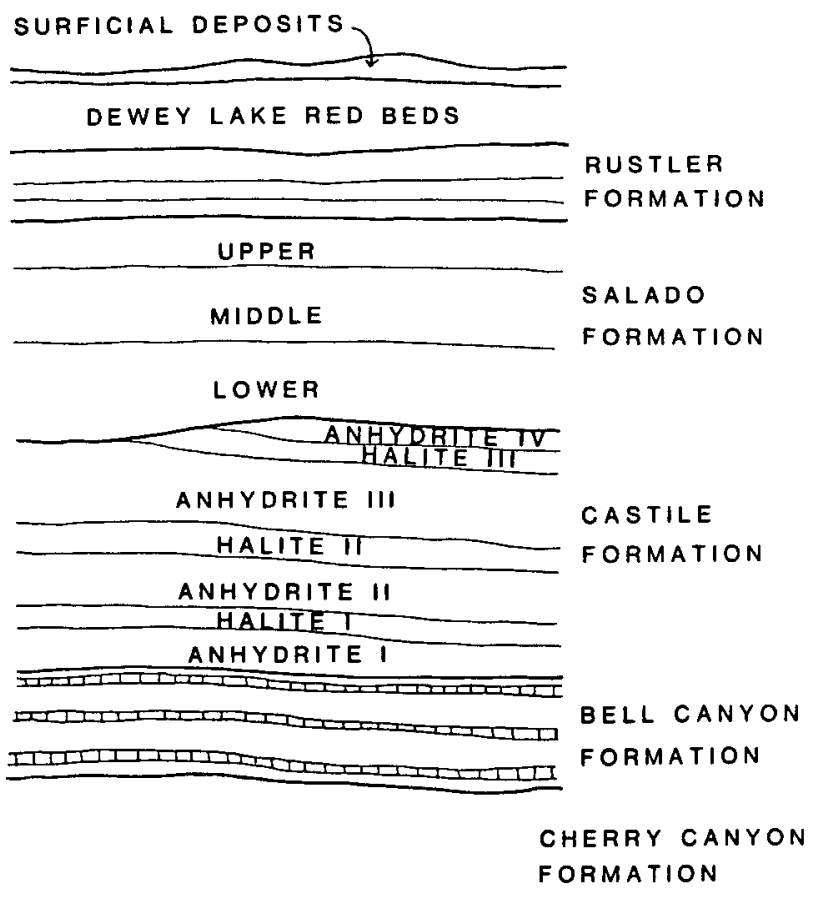

Figure 2. Idealized cross section, Northern Delaware Basin (adapted from Lambert, 1983)

\section{Results of Log Correlations}

This report is an accumulation of geophysical well-log data from 276 drillholes in the northern Delaware Basin. The maps (Figures 3 through 26) portray these data in a $30 \times 36-\mathrm{mi}$ area. The 24 contour maps are based on our log correlations and include maps of stratigraphic surfaces and isopach maps. The results of this study are presented here, and detailed discussions of the methods that we used for correlation are presented in later sections. The following basic observations can be made from the contour maps:

- The units incline towards the Capitan Reef, with deflection of contour lines into a parallel position with the margin of the reef.

- Away from the margin of the reef, the contour lines run N-S, reflecting a west-to-east dip for the stratigraphic surfaces.

- Stratigraphic surfaces reach their maximum depths within the southeast corner of the map area.

- Within the Rustler and Salado Formations, a linear high that runs northwest to southeast appears in the southern third of the map area. This high becomes indistinct across the SaladoCastile contact. With depth, Castile surfaces more closely parallel the top of the DMG.
- Local highs and lows are observed for any given surface within the map scale. The number of highs approximately equals the number of lows.

- Isopach maps show a generally uniform thickness in the middle of the map area, with thickening or thinning adjacent to reef and irregular structures along the southern edge of the map area.

- The middle Salado is more constant in thickness than the upper or lower Salado.

- Very broad zones of thickening and thinning are observed in the lower Salado and Castile in the southern third of the map area.

The observations made above are based on broadscale correlations of oil- and gas-industry holes. Therefore, the detail of structures in the area adjacent to the WIPP site may be lost at the scale of mapping in this report. Structures such as the FC-92 depression (Davies, 1983 and Snyder in Borns et al, 1983) are lost. For relatively fine-detail structures in the WIPP area, the reader is referred to Griswold (1977).

As the study progressed, we became aware of the following considerations of specific interest to the WIPP project:

- Stratigraphic picks can vary among workers. Therefore, such picks need to be reviewed and compared by the entire working group.

- Variations in log signature, caused either by operational conditions or real stratigraphic complexities, can make stratigraphic picks ambiguous.

- MB 136, Cowden Anhydrite, Infra-Cowden, and Anhydrite III are commonly the most ambiguous surfaces to pick; therefore, isopachs that are based on MB 124 and the top of Halite II are less prone to error.

- Assumptions of post-Permian lateral continuity of key marker beds are not always valid.

- Structures based on one-hole anomalies need to be carefully evaluated for ambiguities in picks, errors in transcribing data, quality, and type of $\log$ used, and consistency with nearby holes. After such checks, some one-hole anomalies remain. In the course of constructing the contour maps in this report, we drew contour nests where the one-hole anomaly is supported by trends in adjacent holes. However, if adjacent holes are not consistent, we did not deflect the contours but marked the anomalous hole with an asterisk. 


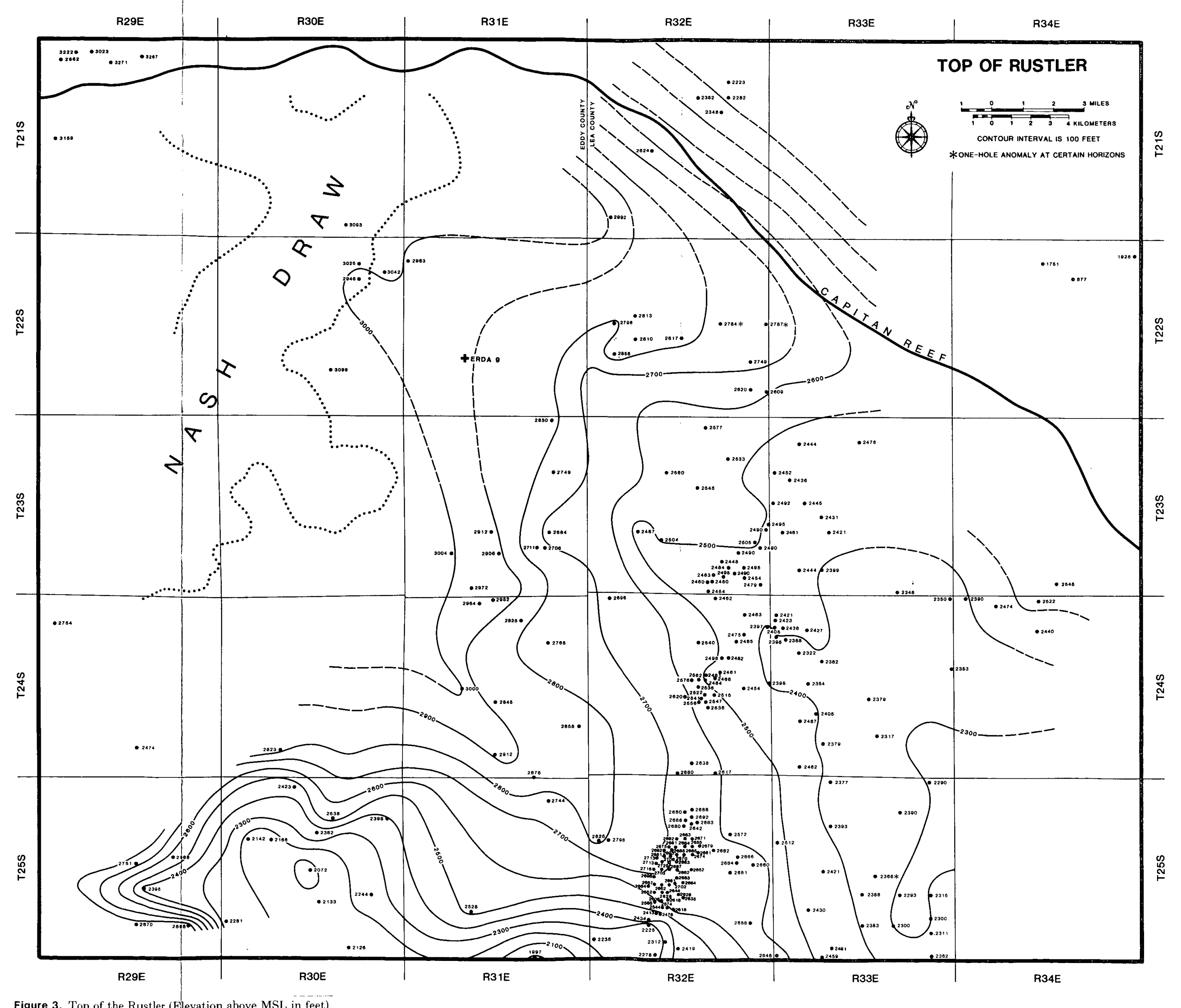




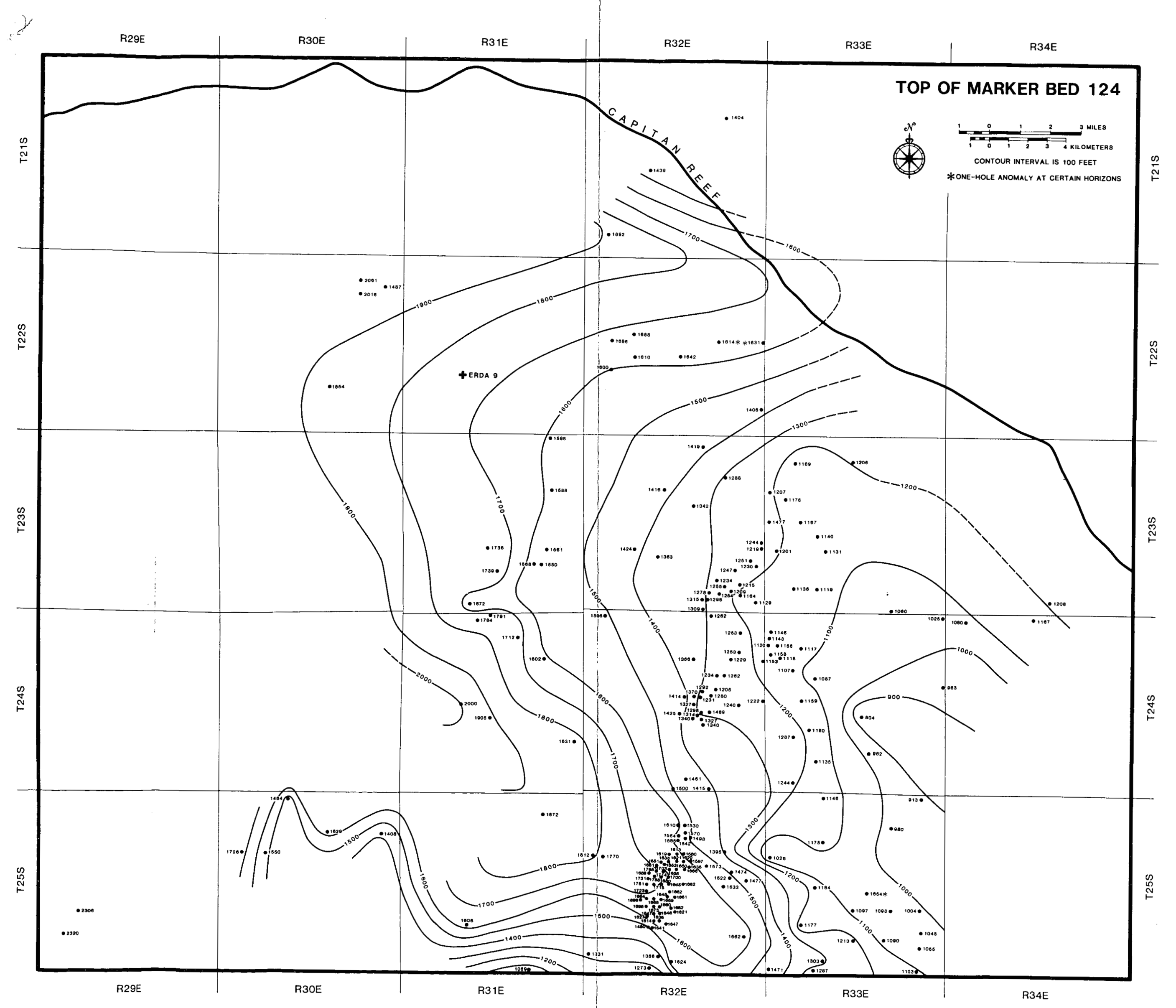

Figure 5. Top of Marker Bed 124 (Elevation above MSL in feet) 


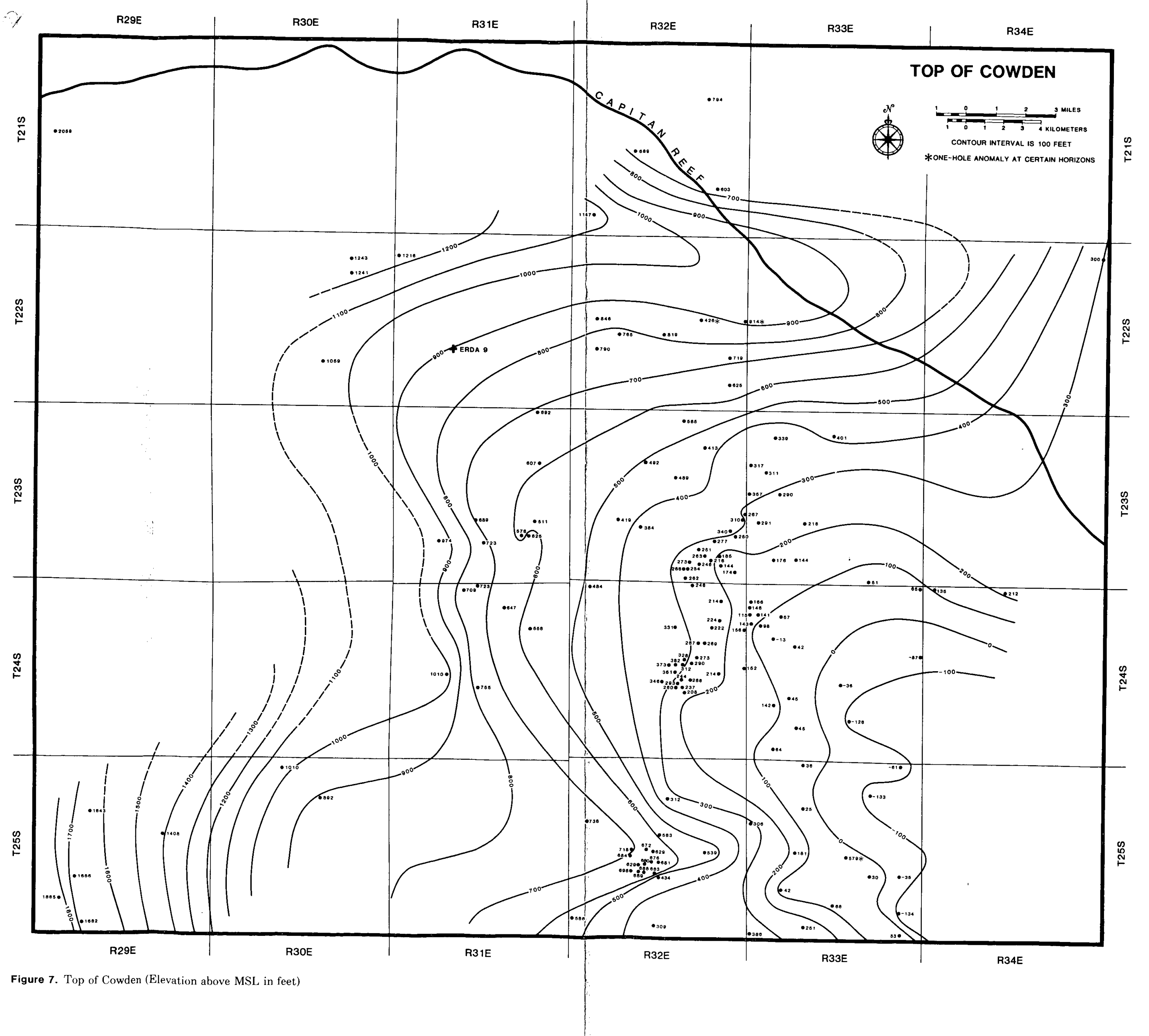




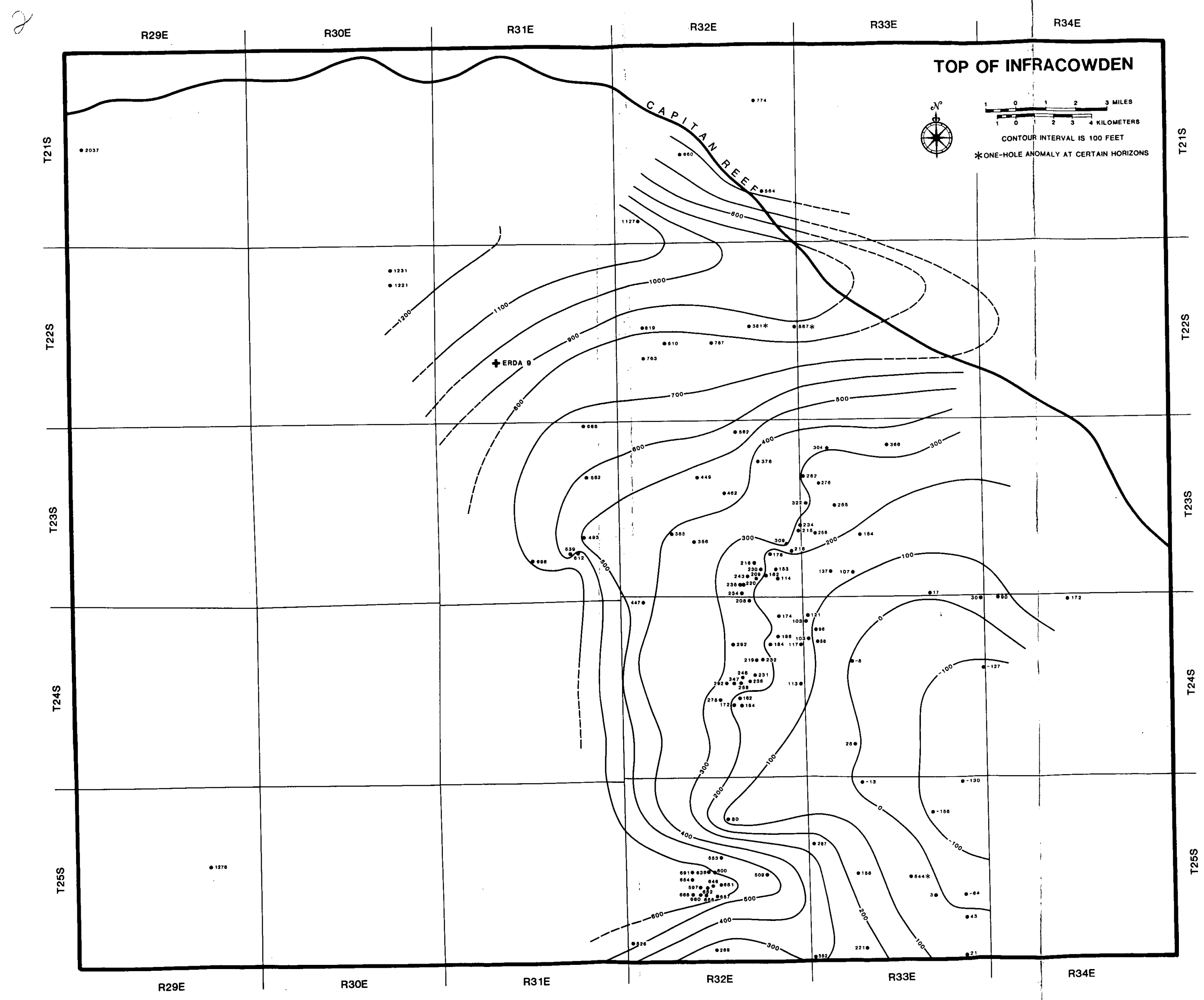

Figure 8. Top of Infra-Cowden (Elevation above MSL in feet) 


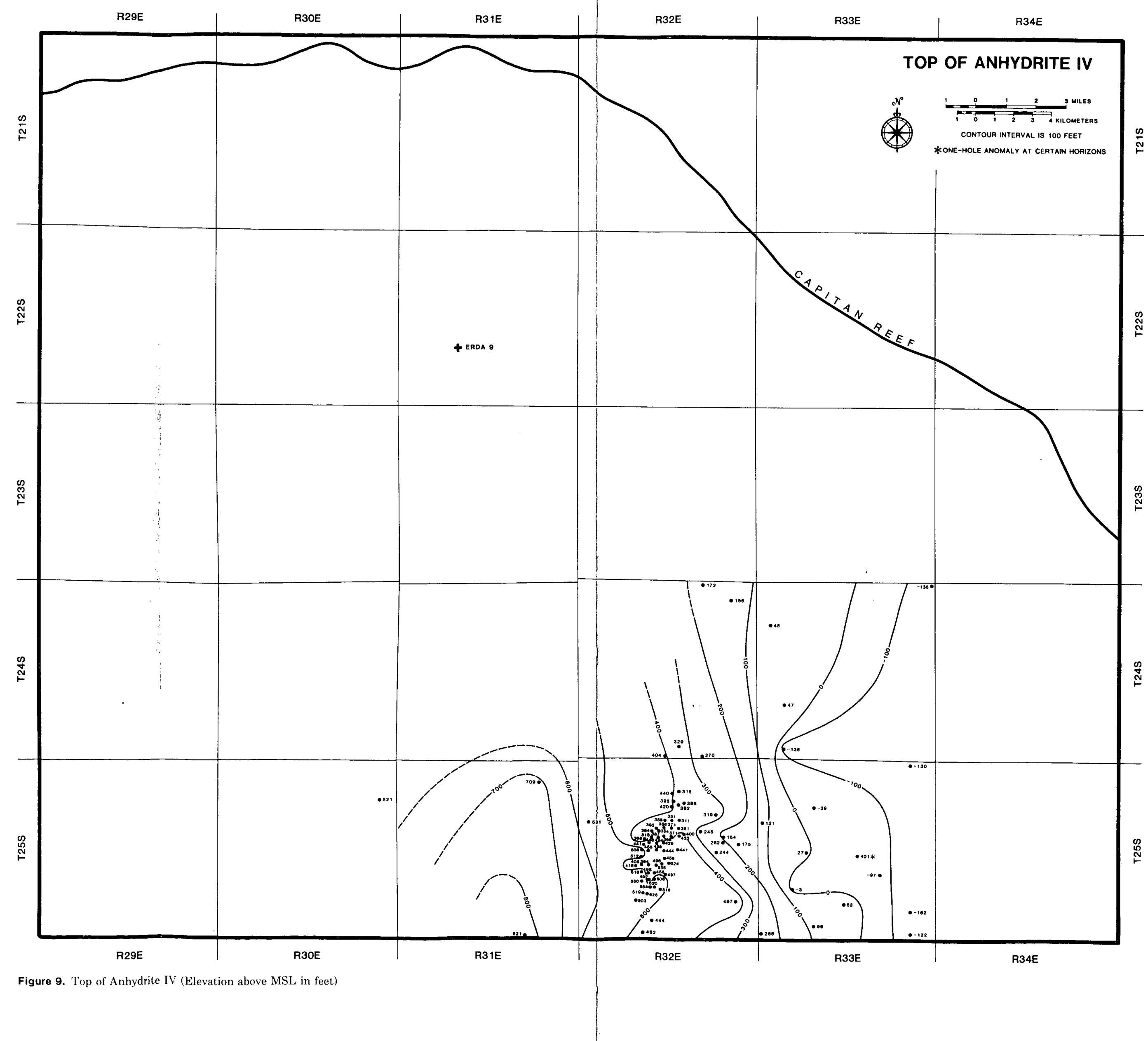




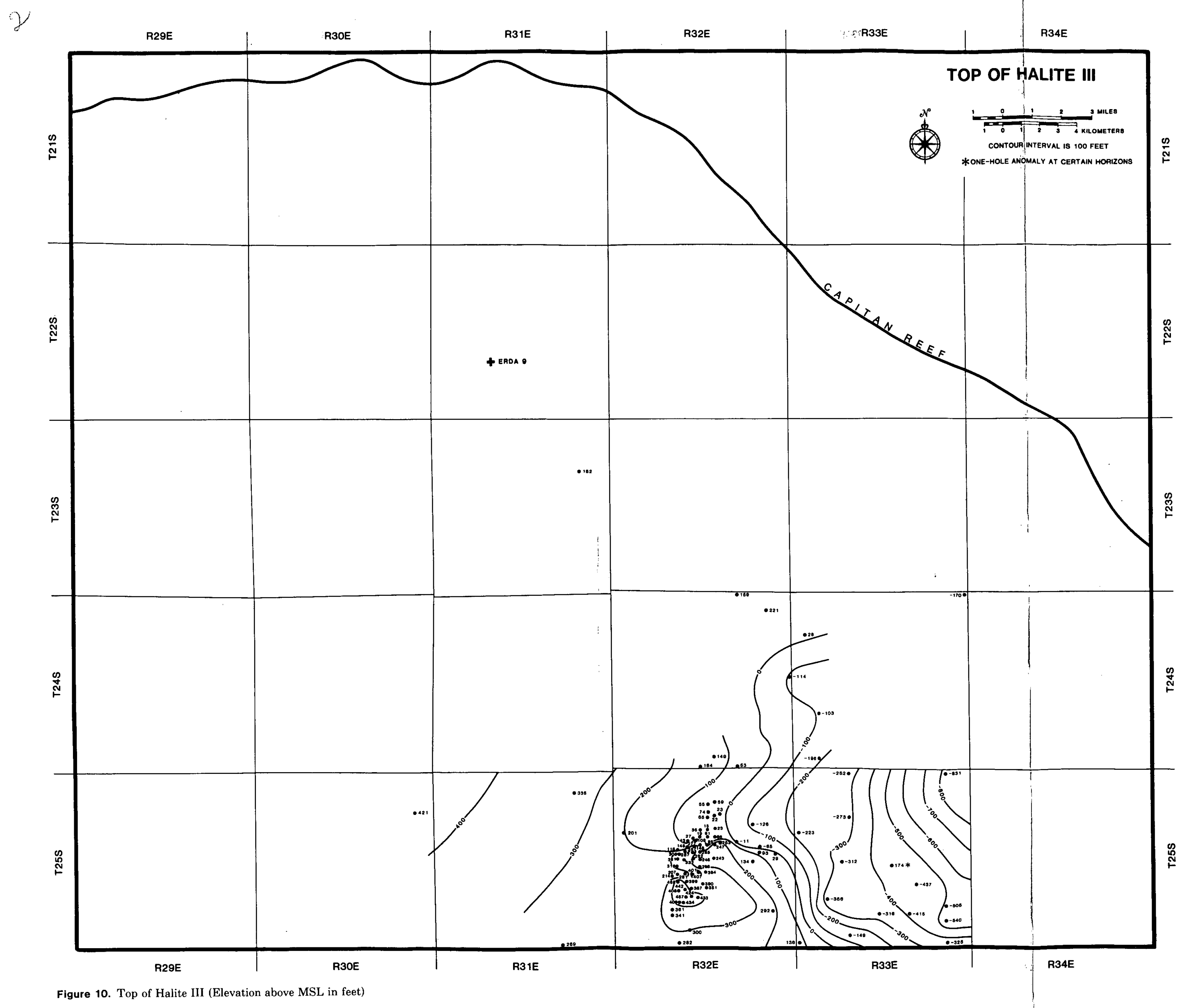

Figure 10. Top of Halite III (Elevation above MSL in feet) 


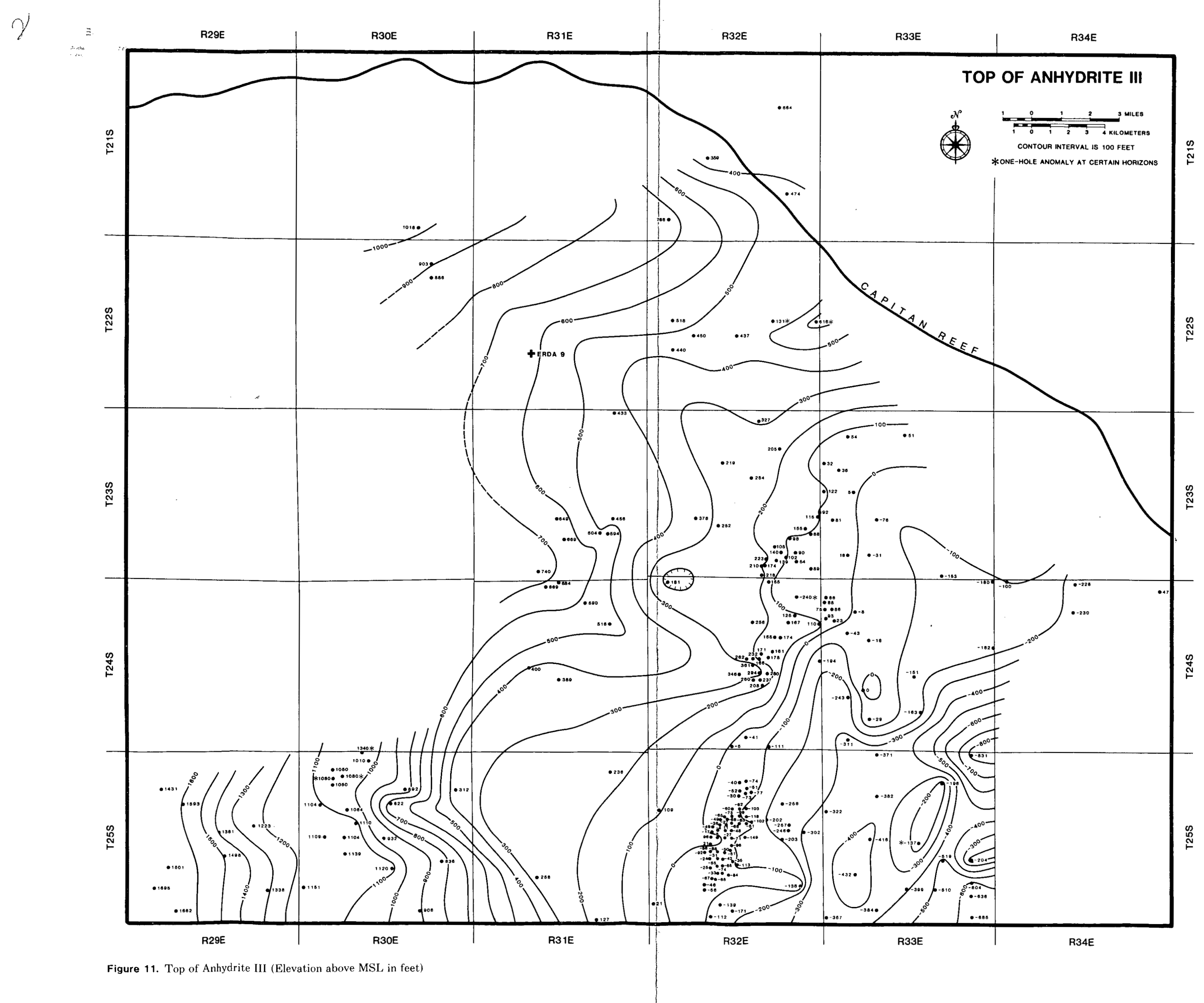




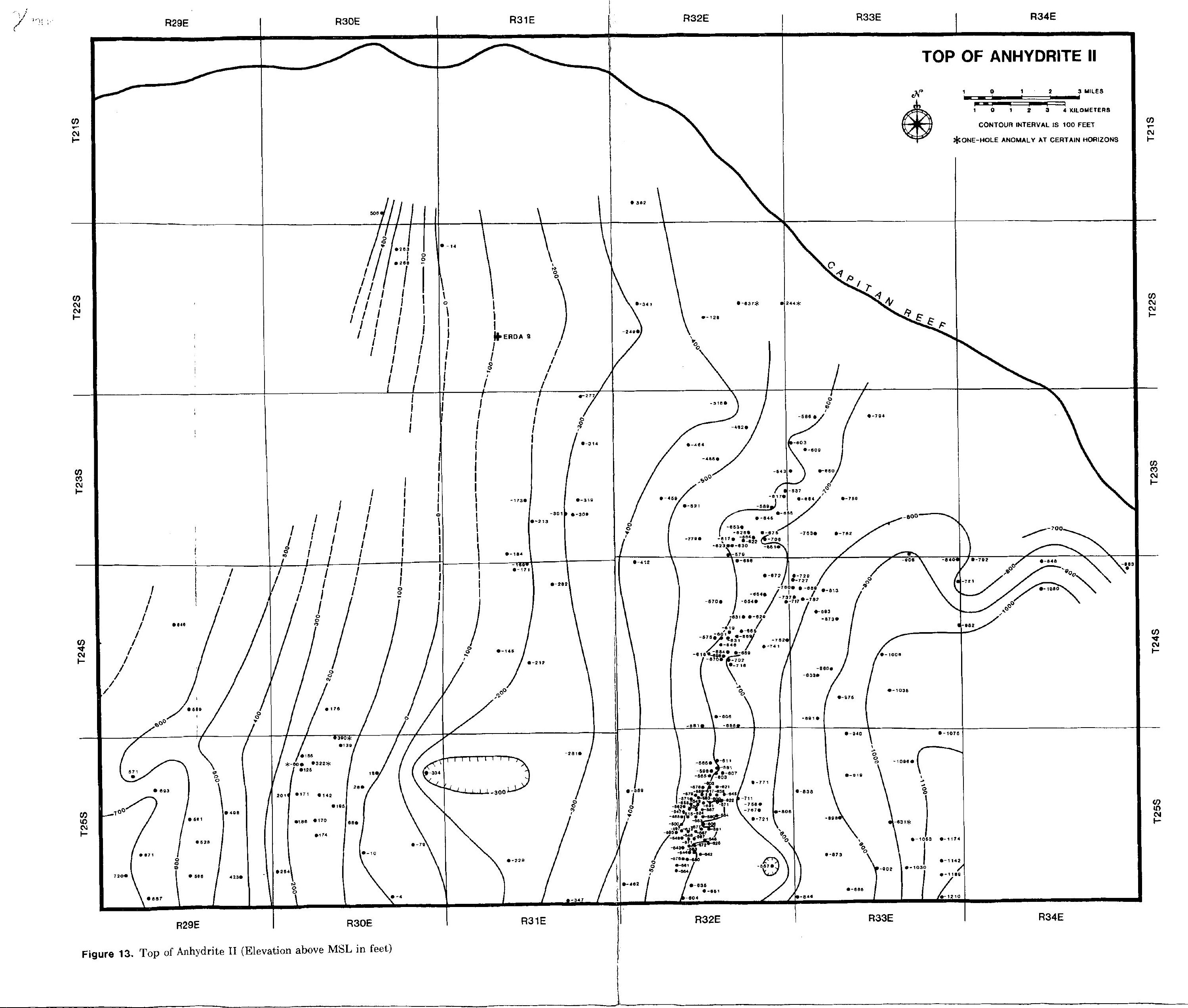




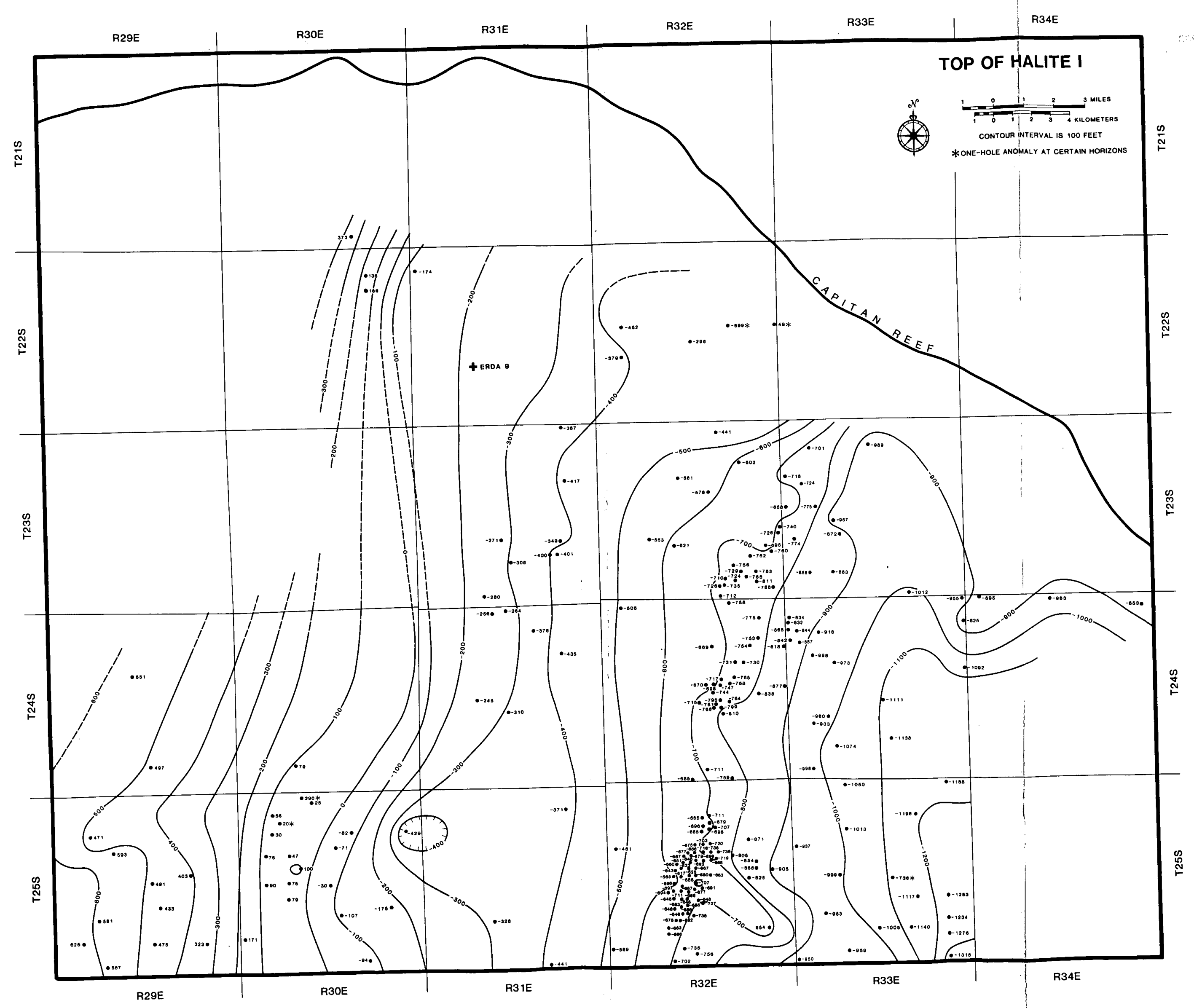

Figure 14. Top of Halite I (Elevation above MSL in feet) 


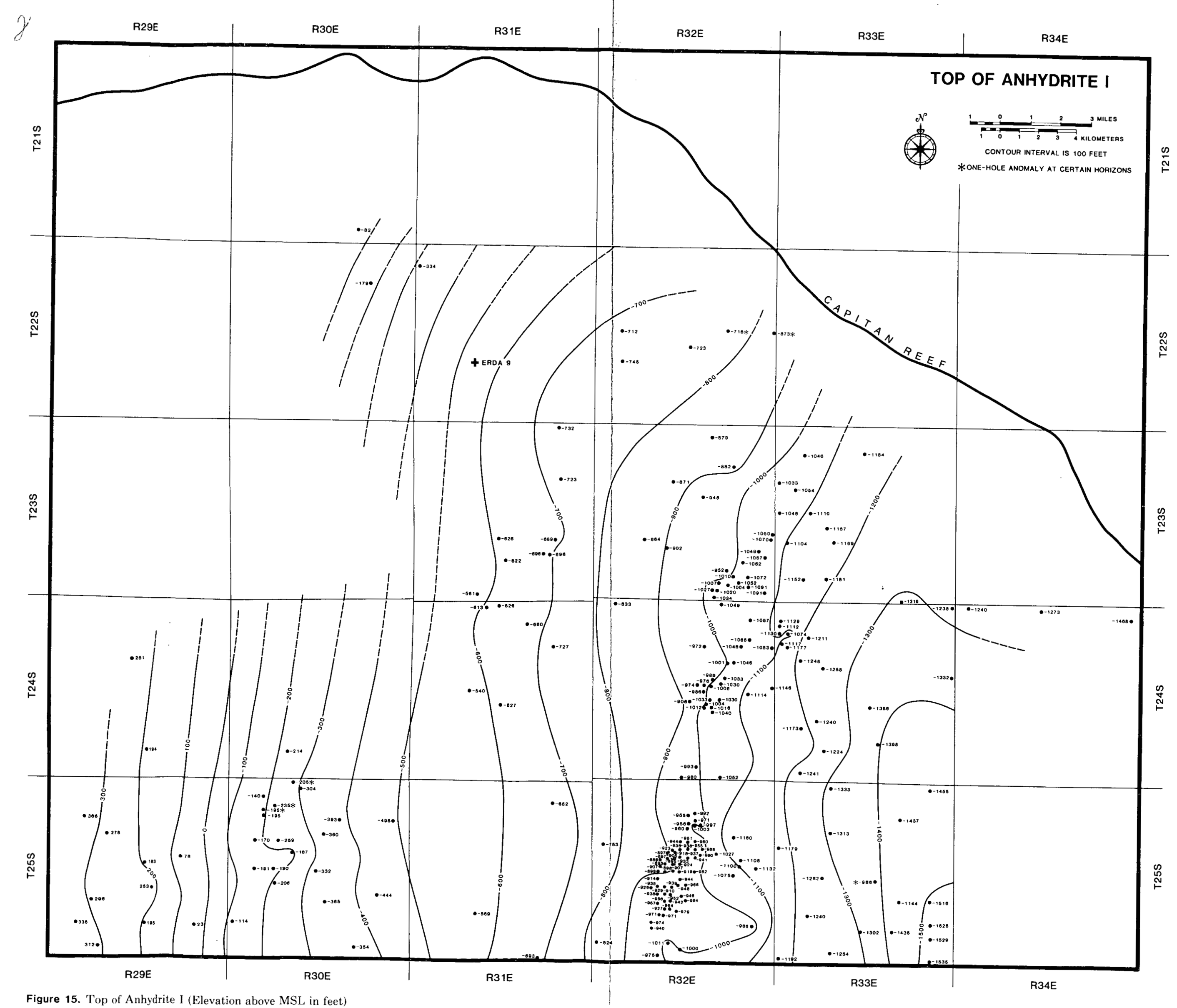




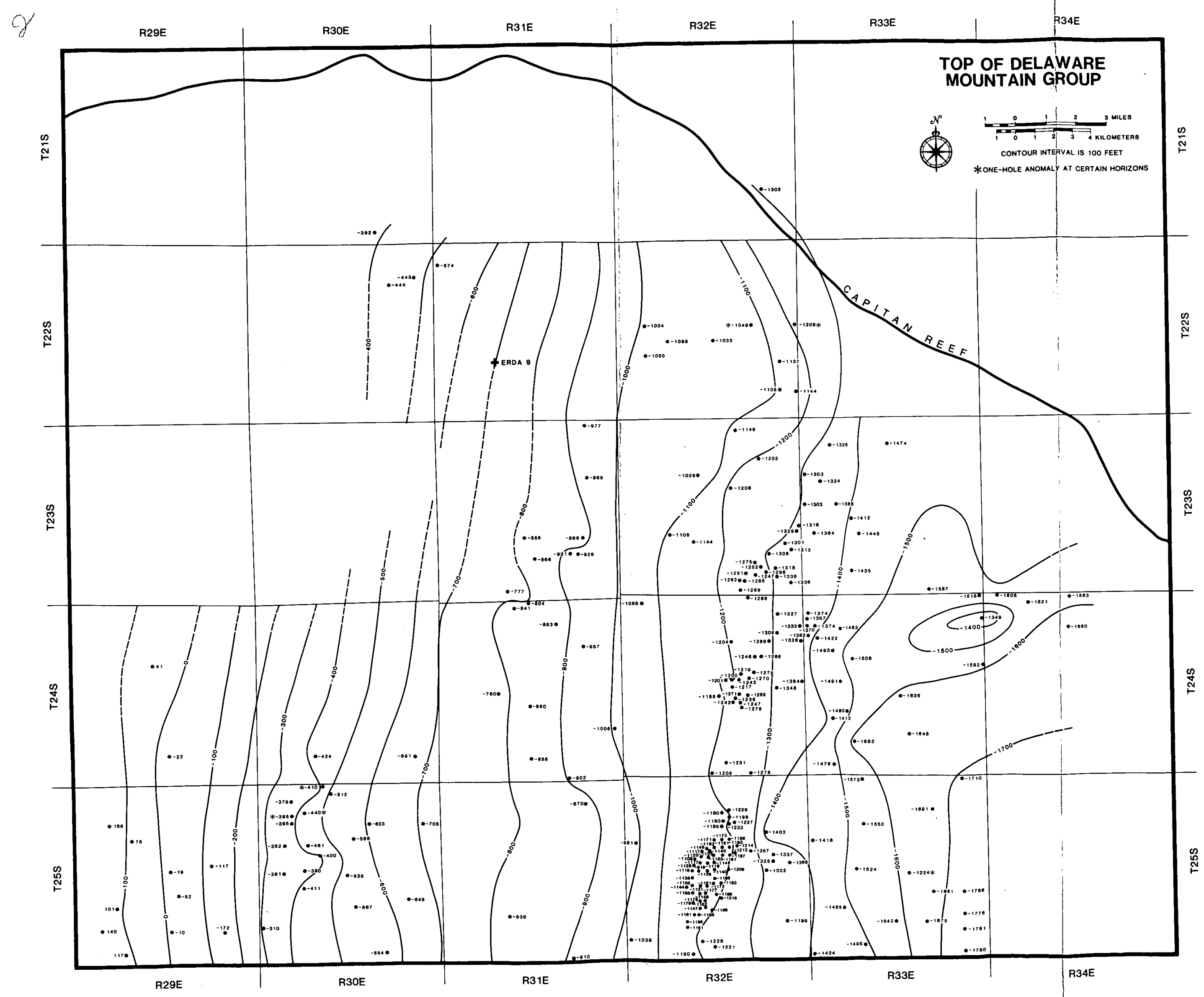

Figure 16. Top of Delaware Mountain Group (Elevation above MSL in feet) 


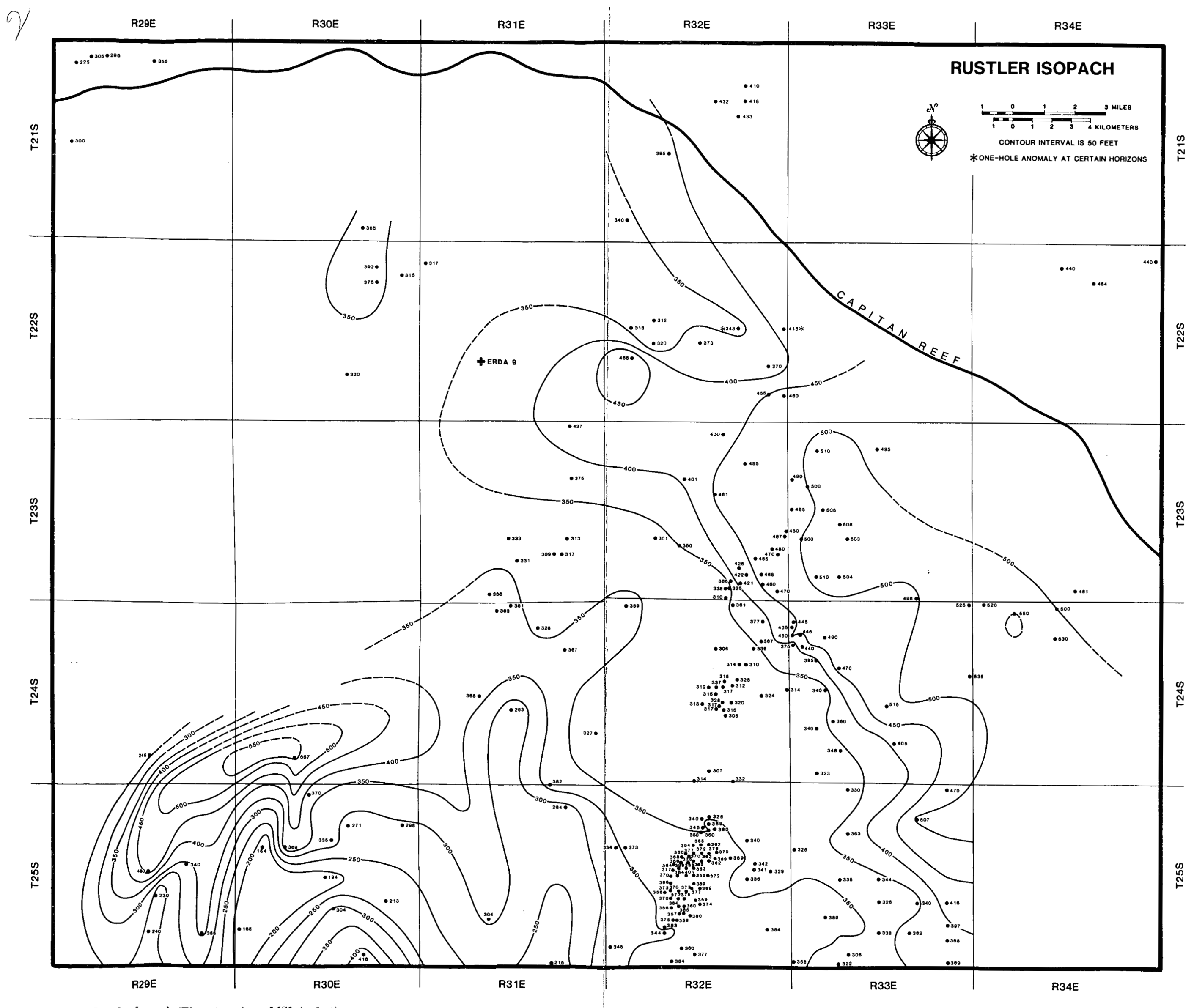

Figure 17. Rustler Isopach (Elevation above MSL in feet) 


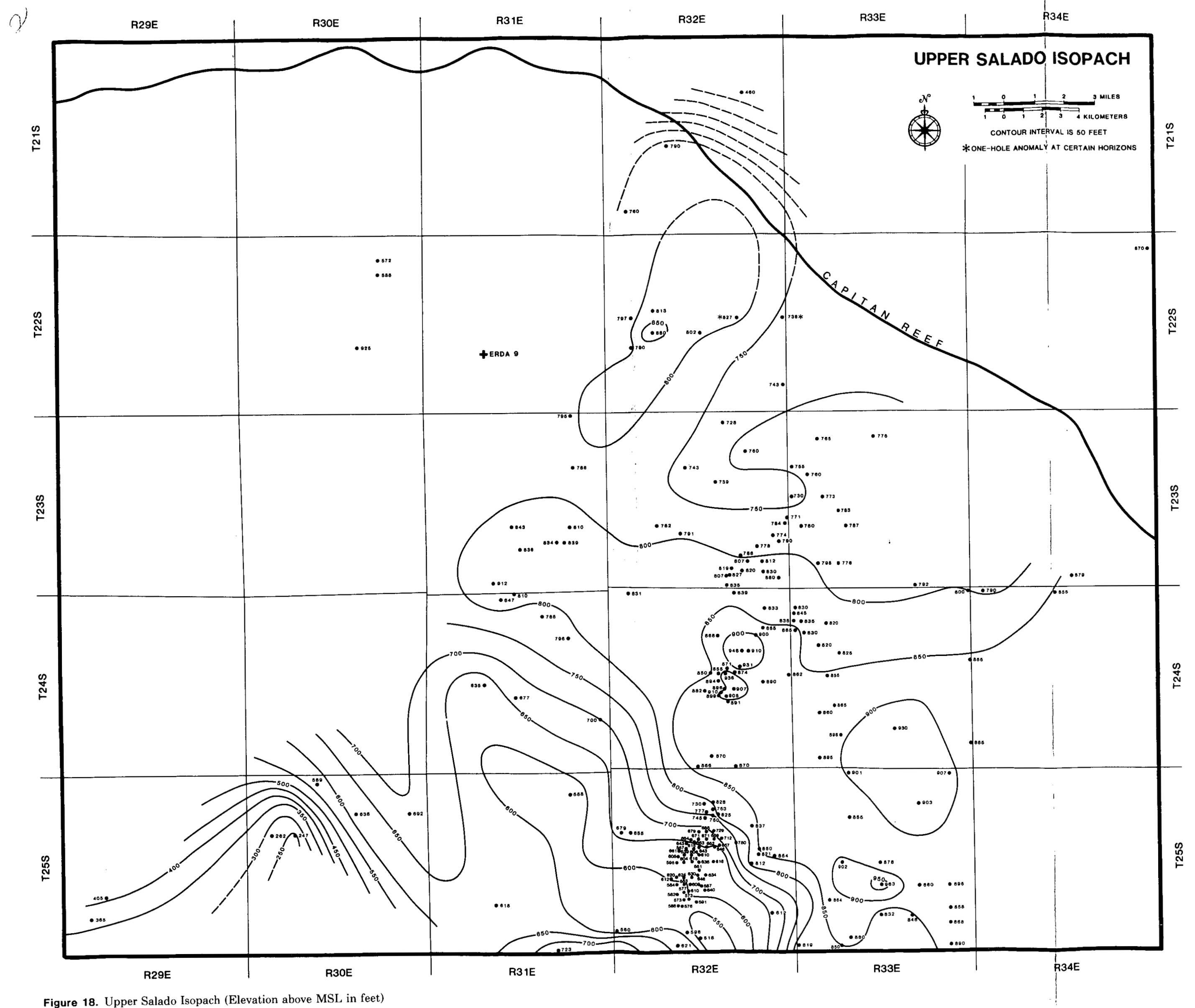




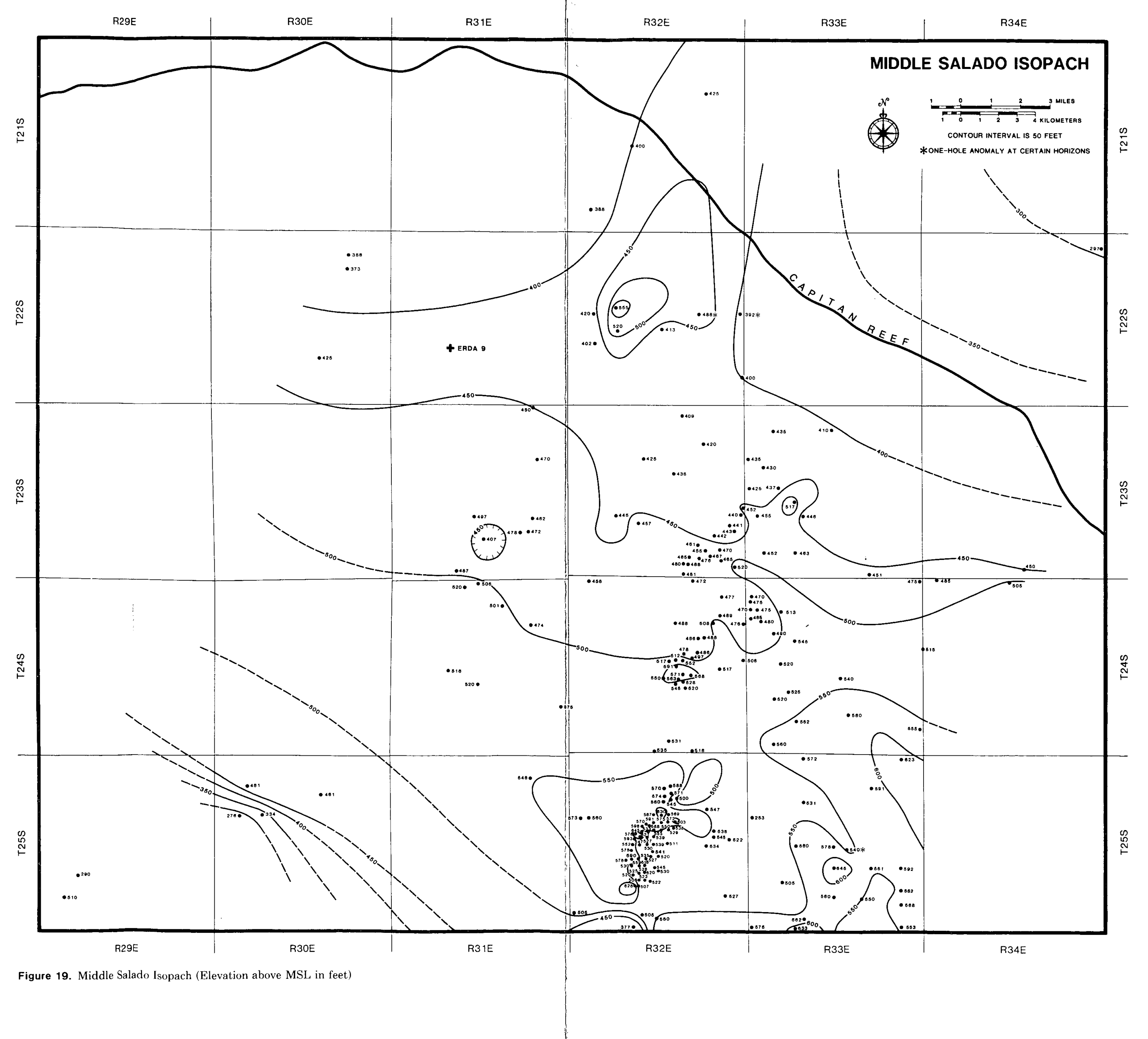




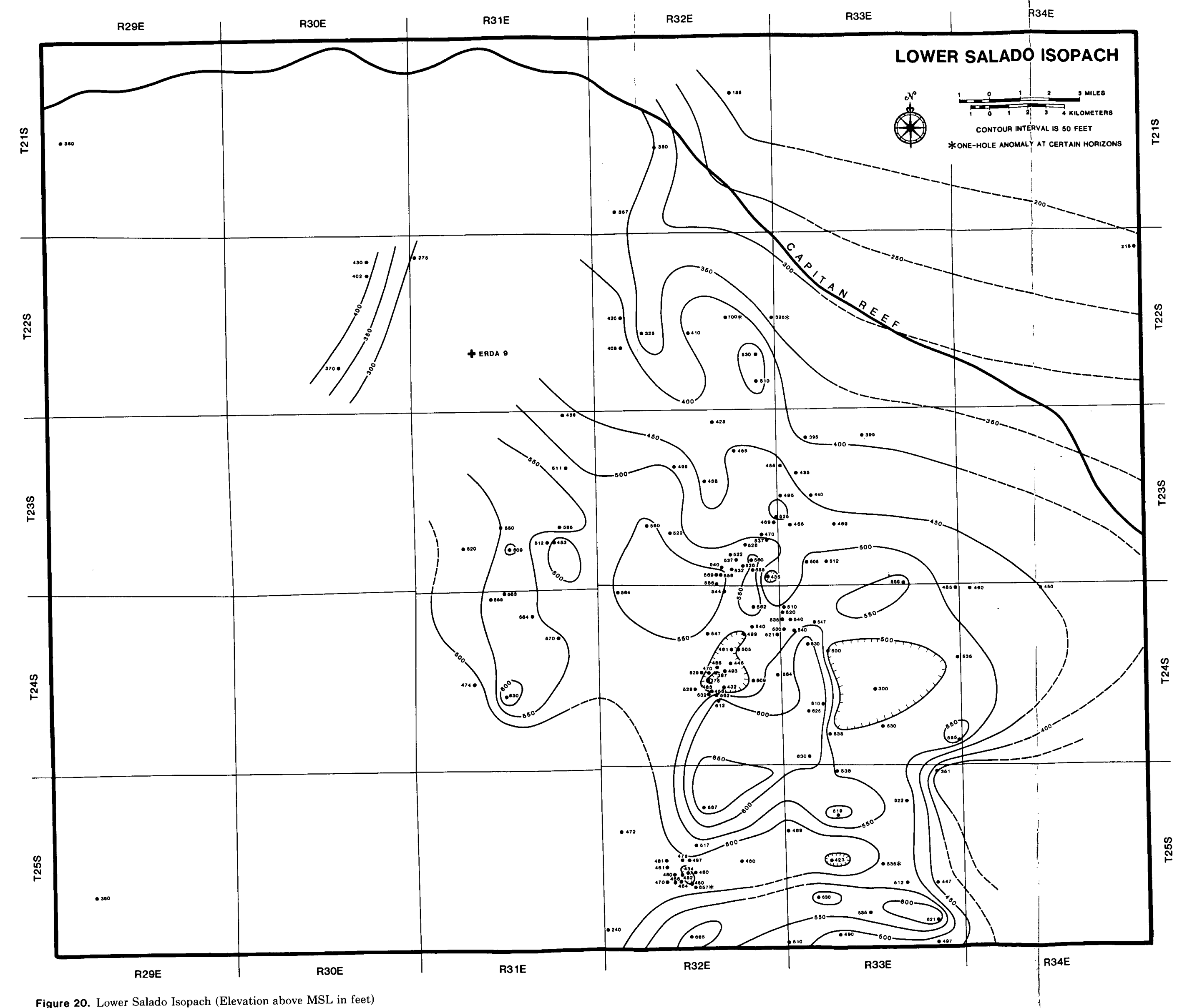

Figure 20. Lower Salado Isopach (Elevation above MSL in feet) 


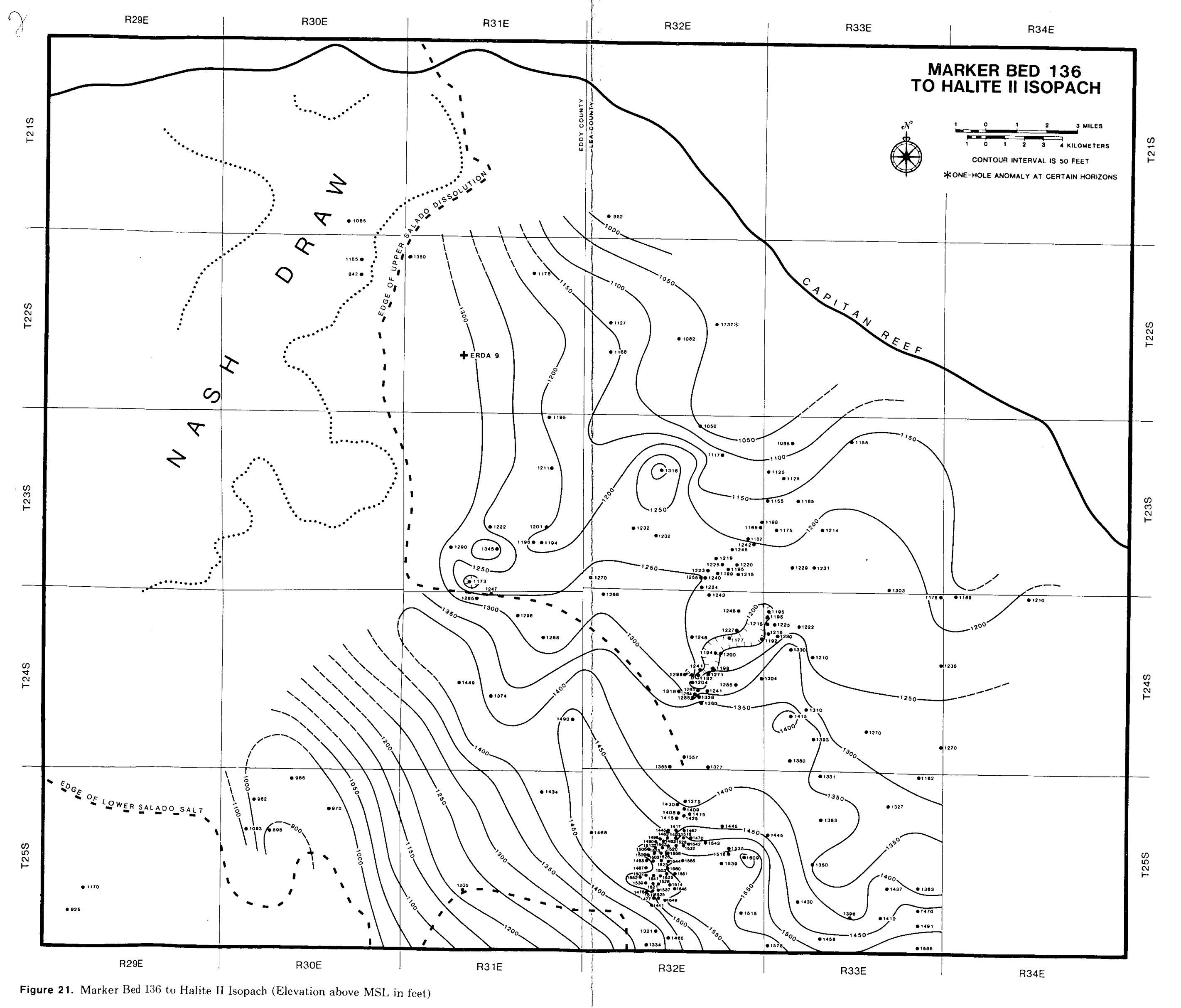


$\gamma$

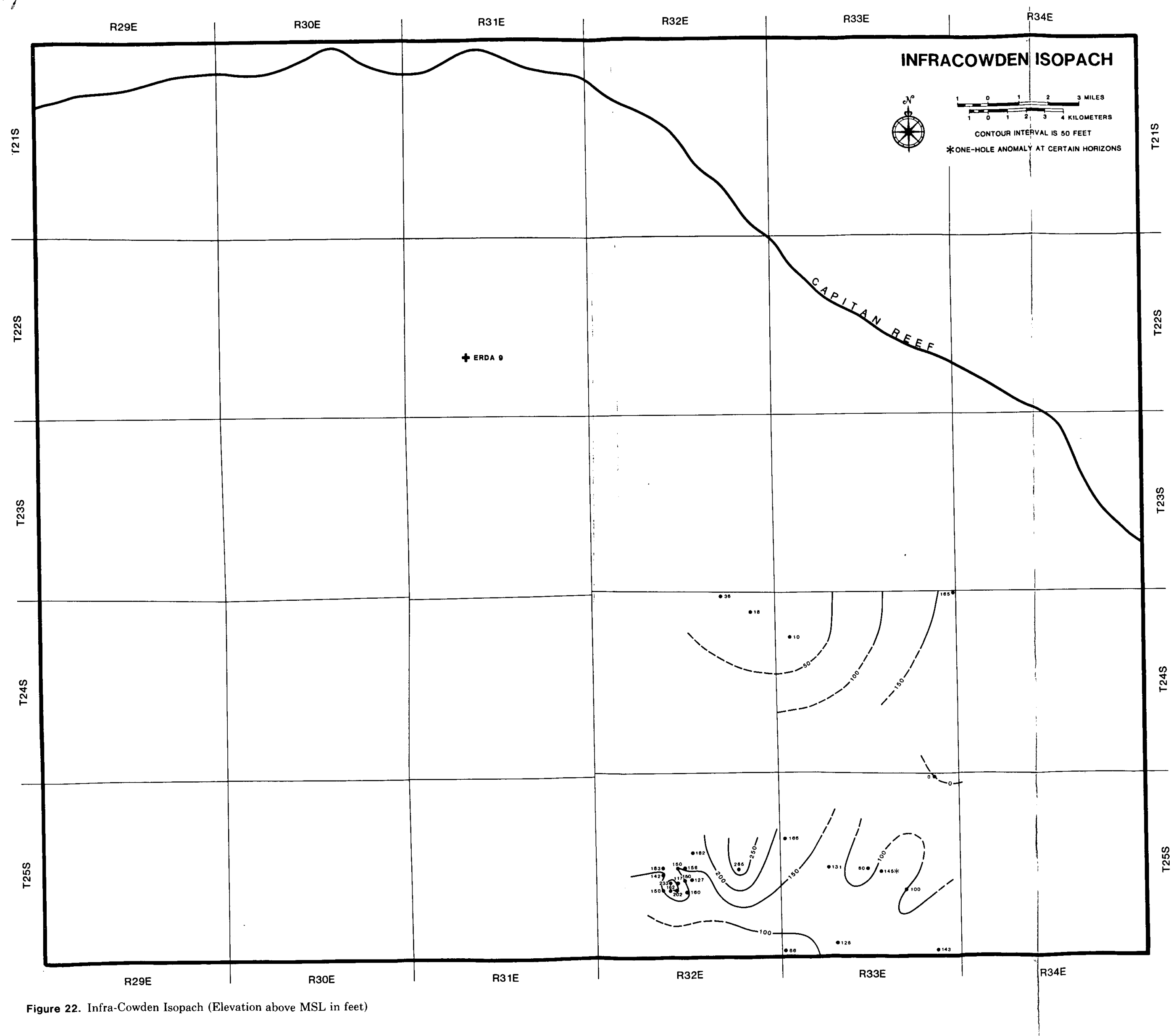




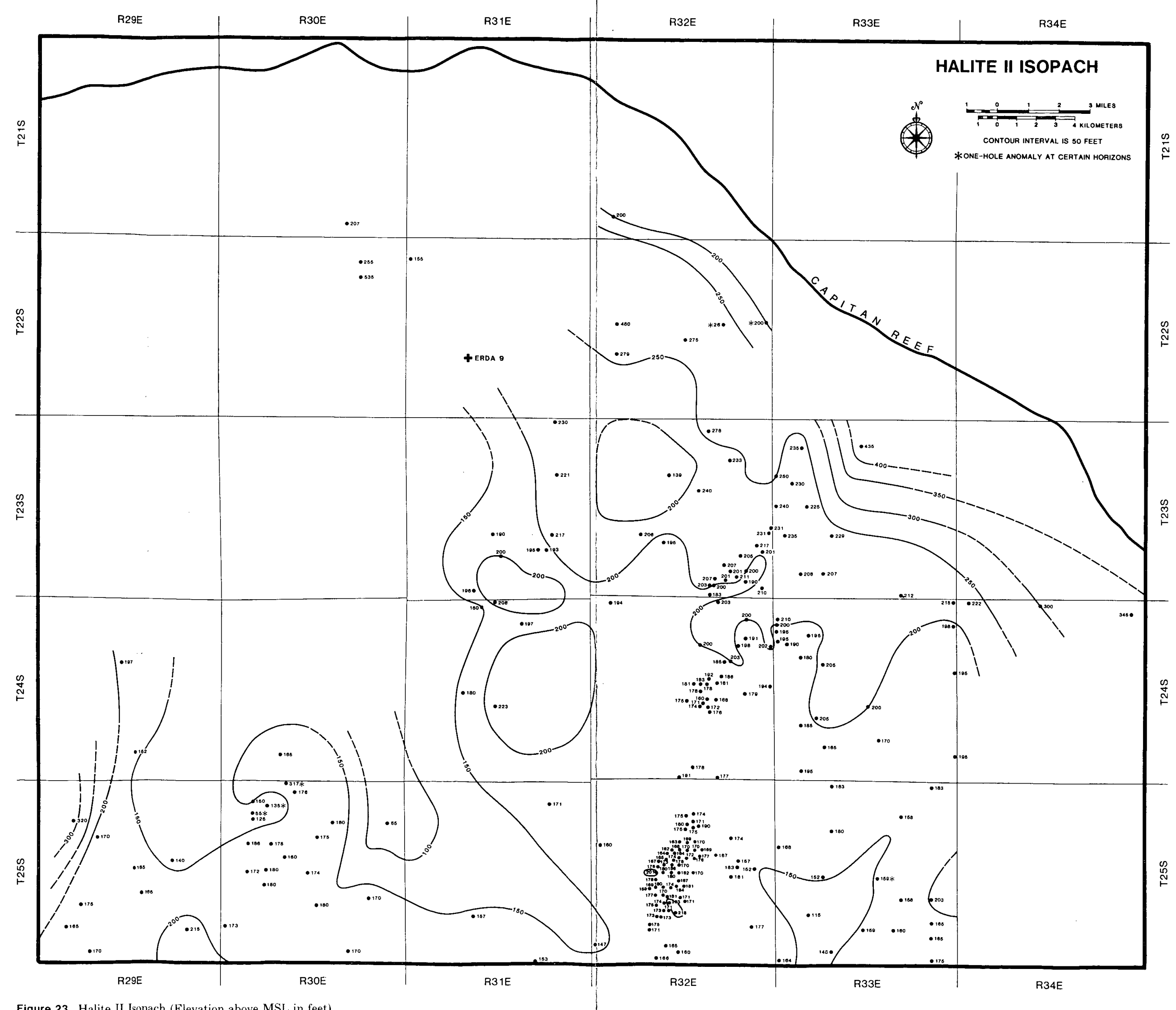




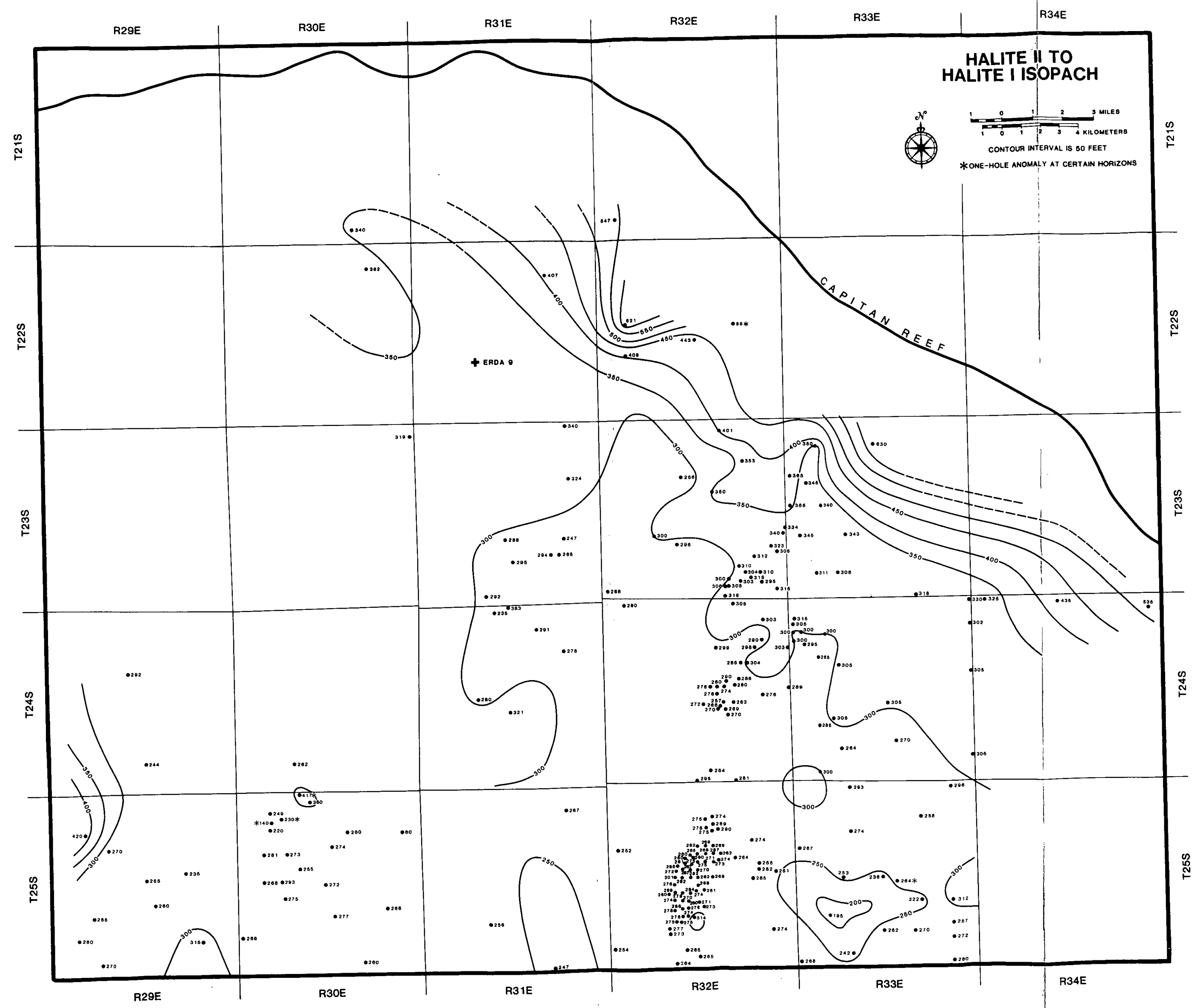

Figure 24. Halite II to Halite I Isopach (Elevation above MSL in feet) 


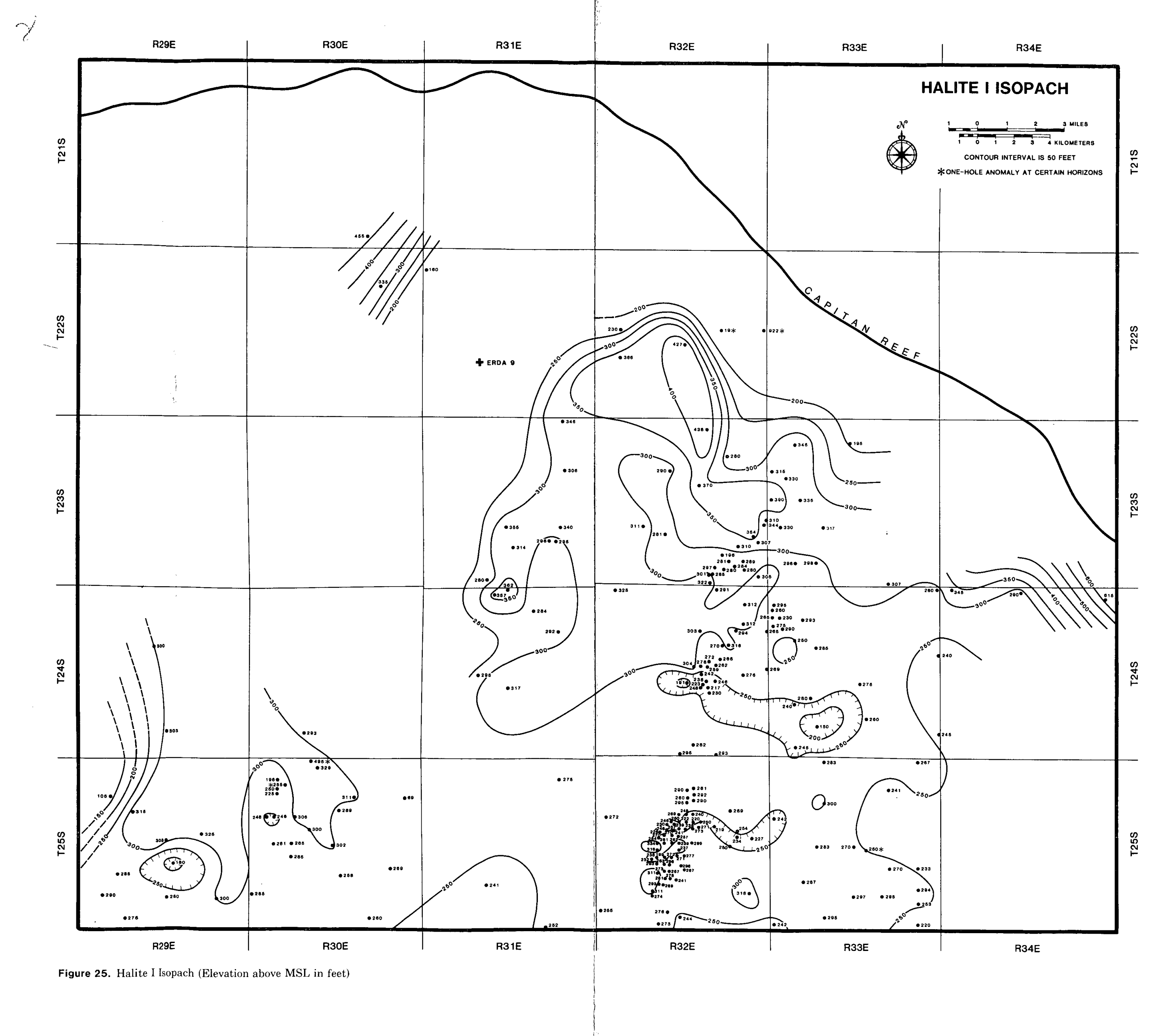




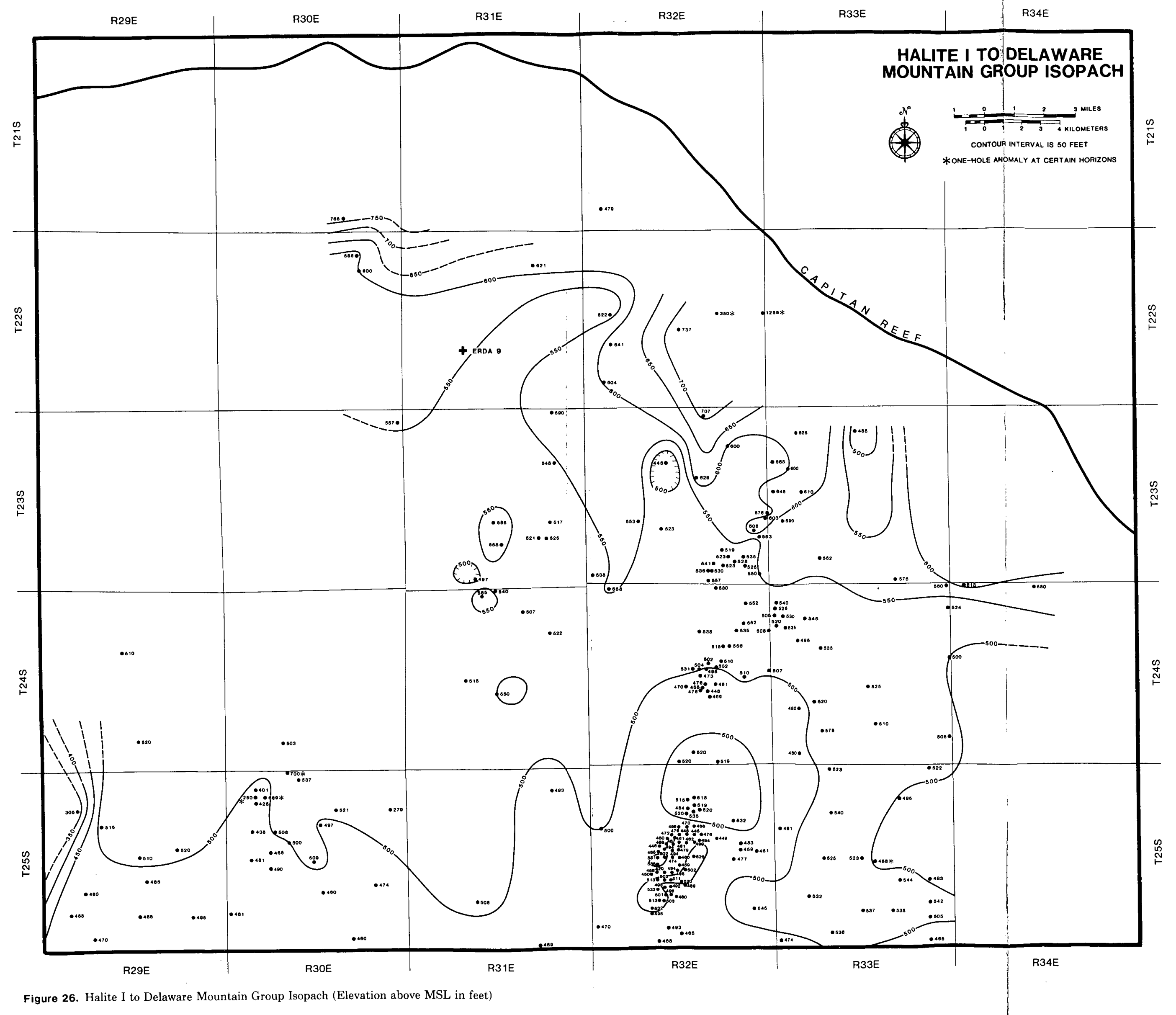

33 


\section{Methods and Problems of Log Correlation}

A file of well-location symbols, each with an associated identification text, was constructed on an Applicon Graphics System. Well locations were digitized from well ownership maps published by the Midland Map Company. The selected wells were marked on the maps and individually identified by unique sevencharacter identifiers. An example identifier is P08,2533 in which the well name is identified by a letter (PO8,2533) and in which the section (PQ88,2533), the township (PO8,2533), and range $(\mathrm{PO}, 2533)$ for the hole are numerically identified. The alphabetic prefix is a letter taken from the name of the well that uniquely identifies a given well in a single section.

A data set of depths for stratigraphic surfaces was compiled for each hole from geophysical logs. Each data set had a field of 18 entries relating to well location and identification, as well as stratigraphic information. Appendix A is a complete printout of the data sets with wells arranged by location. The Applicon was also used to produce base maps for isopach contours and structure contours on upper surfaces of the rock units.

We considered primarily the hydrocarbon industry holes in the region. Stratigraphic correlations, based on Waste Isolation Pilot Project (WIPP)related holes in the site area, were previously reported by Griswold (1977) and Snyder (Chap. 2 in Borns et al, 1983). We used well logs from ERDA 9 on which the WIPP site is centered as a reference log for stratigraphic picks in the Salado, which was completely cored in ERDA 9.

Many of the boreholes in the Delaware Basin were not logged in the upper $4000 \mathrm{ft}$ of the section, since economically significant oil and gas are not found in this interval of interest for our study. Thus many of the available logs do not include sections above the Delaware Mountain Group (DMG). Other logs were discarded because of uncertainty as to the true location of the borehole, or because the record was obscured by noise. In the end, information from 276 wells was used (Figure 1).

There are several important components of log correlation. One component is determining a characteristic geophysical signature for the ideal stratigraphic section. A second component is applying the ideal log signature to more ambiguous log signatures and, in turn, determining the limits to picking stratigraphic markers from the logs. A third component is recognizing significant departures in the local stratigraphy or in its geophysical signature. Both types of departure may confuse the process of log correlation. In the following, we try to show how these components have affected the interpretation of logs in this study and in other studies in the region.

\section{Ideal Well-Log Signatures}

Logs can be used in two basic ways:

- To determine specific properties, such as rock type, porosity, and permeability within a single hole

- To correlate hole-to-hole the continuation of structure or rock unit.

The latter requires core data to corroborate the inferred structure or unit identity. Logs such as densilog, gamma ray, and acoustilog allow the dominant rock-forming mineral (e.g., anhydrite, halite, polyhalite or clay) to be inferred for the section of interest. A specific example is the use of the gamma-ray spike to identify the base of the Cowden Anhydrite. The question arises whether specific rock types such as dissolution breccias can be inferred from log signatures. Logs alone identify only a physical property from which to infer mineralogy. To identify a rock type, some assumptions must be made regarding the unit's mineralogy, porosity, density, etc. This can be done only with core truth, as Lambert (1983, p 75) has done by using logs from Nash Draw where dissolution is known to occur. The characteristic signature from Nash Draw is used, herein, to distinguish dissolution residues elsewhere in the basin. Even in this example the assumptions are important; e.g., that dissolution processes are similar between Nash Draw and the rest of the basin. However, other processes such as original rapid depositional oscillations in rock type may result in log patterns similar to those of a dissolution residue. Thus, the validity of any log interpretation depends on its corroboration by drill core and correlation to other logs from additional holes.

To develop a regional correlation map, a geologist needs to convert the geophysical data of well logs into stratigraphic picks. This process suffers from various degrees of subjectivity. We will begin with a discussion of ideal log signature and progress into the complications of stratigraphic picks.

The most useful logs for stratigraphic picks in the evaporite section of the Delaware Basin are Borehole Compensated Sonic (BHC) or Acoustilogs and Natural Gamma-Ray Spectrometry (NGS,or $\gamma$-log). The 
marked density differences between halite and anhydrite or polyhalite interbeds show up distinctly in the $\mathrm{BHC}$ and Acoustilogs. The $\gamma$-log can often pick up clay seams that characterize the base of certain marker beds.

Figure 27 shows the ideal well log signature on which stratigraphic picks were based in this study. Using this log signature as a basis, we made picks where possible in 276 holes for the tops of the following units: the Rustler Formation, the Salado Formation, Marker Bed 124, Marker Bed 136, the Cowden Anhydrite, the Infra-Cowden Halite, Anhydrite IV, Halite III, Anhydrite III, Halite II, Anhydrite II, Halite I, Anhydrite I, and the Bell Canyon Formation.

\section{Ideal Versus Ambiguous Logs}

The information obtainable from a log can vary greatly due to whether the $\log$ is characterized as ideal or ambiguous. Examples of ideal and ambiguous logs are shown in Figures 28 and 29: Figure 28 shows the Rustler, Salado, and uppermost Castile Formations in an ideal $\log$ (ERDA 9) and two ambiguous logs; Figure 29 depicts the lowermost Salado, the Castile Formation, and the upper Bell Canyon in an ideal log and an ambiguous log. (An ideal log is legible and displays the expected signature of the ideal stratigraphy. Ambiguous logs may be too noisy, such as when the sensitivity is too high.) Some of the available logs have been taken through the casing of the well, diminishing the reliability of lithologic information. Departures from the ideal stratigraphy make stratigraphic picks uncertain in ambiguous logs. The problems of ambiguity are discussed in sections below.

In our specific examples of ideal and ambiguous logs (Figures 28 and 29), the ideal log comes from the ERDA 9 borehole, which is substantiated by a drill core. Marker Bed 124 shows its characteristic signature (a double spike) in the ERDA 9 log. In the ambiguous logs, a double peak is not distinct. Lower in the section, the Cowden Anhydrite takes a typical shape in the ERDA 9 density log, accompanied by the characteristic gamma log spike at its base. In the ambiguous logs, the density or acoustilog signature of the Cowden is not identifiable; any pick, if it can be made, is based on a gamma log spike. An ideal log from ERDA 9 is on the left of the figure. (Stratigraphic units in the Rustler, Salado, and uppermost Castile Formations are distinct in the ERDA 9 logs. However, in the well logs from the two holes that are represented in the center and on the right side of this figure, the same stratigraphic indicators are indistinct over the same depth interval.)

\section{Log-Correlation Error}

It is difficult to assess the amount of error incorporated in log correlation and the stratigraphic picks in one well log. To our knowledge, no systematic study has been made of the reliability and reproducibility of interpretations of stratigraphy and correlations thereof between wells. The data used in reports such as this are the products of human inference; hence, errors are individualistic and not systematic. Other possible errors are in the original well data. Examples are in the elevation of the hole; location, whether ground level or, the Kelly-bushing is used as the base level, and deviation of the hole from vertical. Barring total mislabeling of the log, such errors are not significant for the maps in this report since the contour intervals, whether $50^{\prime}$ or $100^{\prime}$, are larger than the possible error.

\section{Basic Assumptions of Stratigraphic Picks}

Important theories for stratigraphic anomalies in the evaporite sequence in the northern Delaware Basin have originated from log interpretation and correlation. Namely, Anderson (1978) and Davies (1983) postulated deep disolution from their regional deformation patterns. Snyder (in Borns et al, 1983) advanced the idea that syndepositional salt flowage was indicated by the Salado-Castile stratigraphy. Borns and Barrows (in Borns et al, 1983) proposed that gravity-driven salt flow, which is possibly ongoing, created the structures observed. In the following sections, we discuss the assumptions made in applying $\log$ data to these theories. We also examine some log data in much finer detail, e.g., single holes or arrays of closely spaced holes, than log correlation maps permit. This exercise allows us to examine the problems of one-hole anomalies and $\log$ correlation in regional interpretation. Important structures are based on stratigraphic picks from logs. Such correlation of a log-signature-lithotype to a specific stratigraphic unit is an inferential process based on certain assumptions:

- Log signatures are easy to interpret and unambiguous (see sections above and Figure 27 for discussion of the ideal $\log$ ).

- All units initially exhibited lateral continuity. For example, Anderson (1983) has stated that virtually every salt bed in the upper Castile can be traced laterally with little change in thickness until it encounters the Salado-Castile unconformity. 
- Stratigraphic Picks

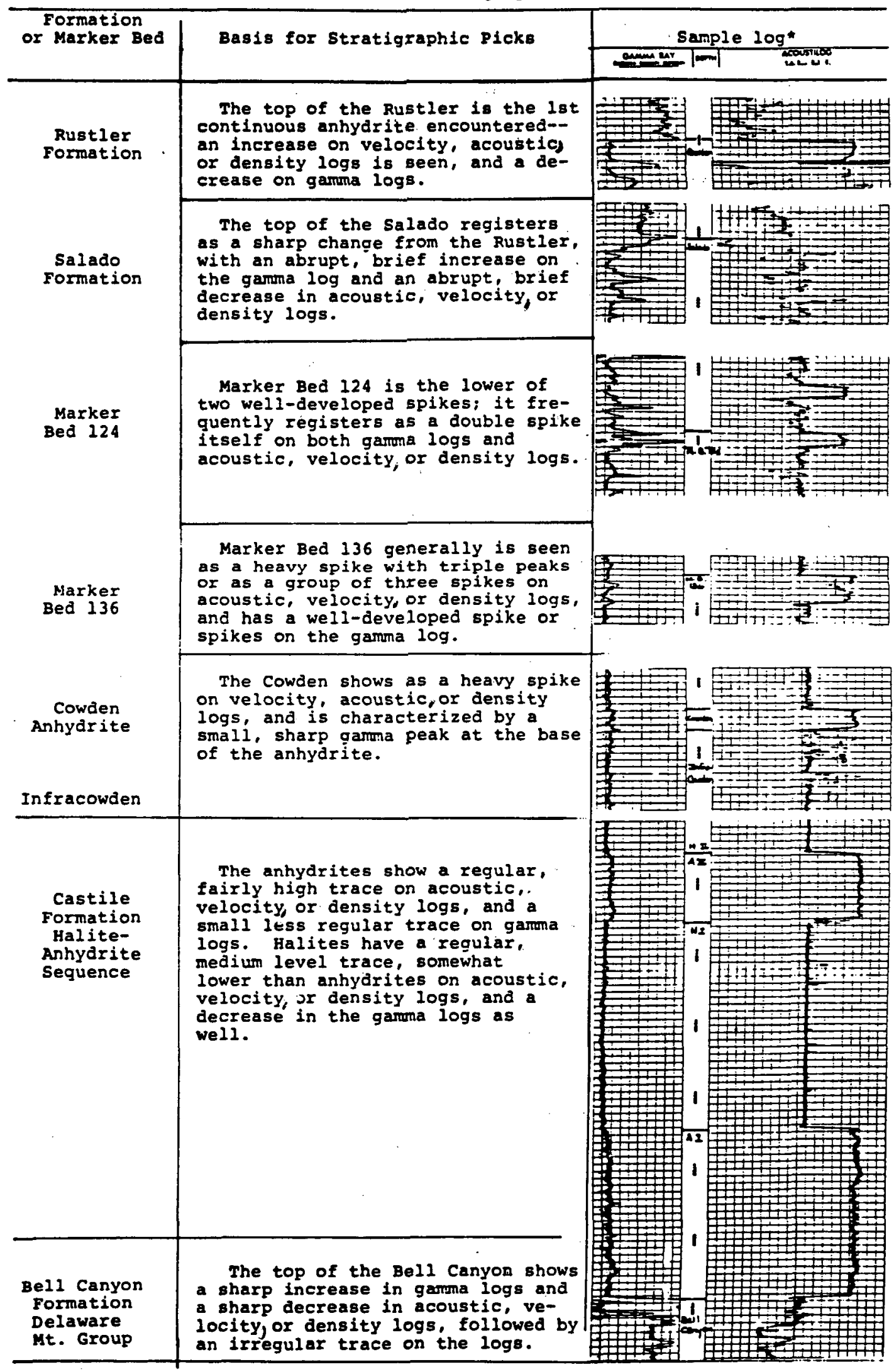

- Sample log from Neil g. Wills Continental State No. 1, T25SR33E, S. 32, Gamma Ray and Acoustilog

Figure 27. Gamma-ray and acoustilog signatures for ideal well log from which the stratigraphic picks are unambiguous (Neil H. Wills Continental State \#1, T25SR33E, S.32) 


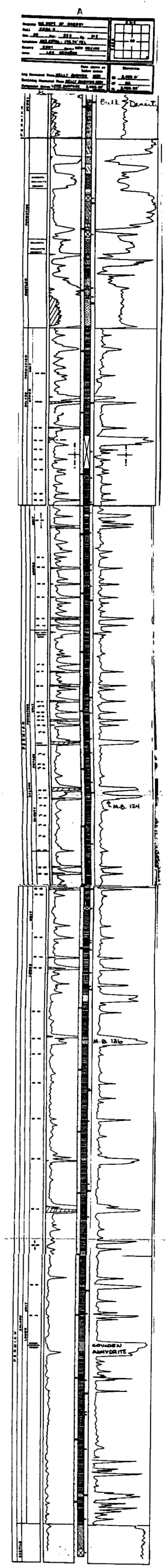

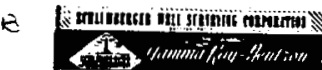 \\ i. \\ iiv $=-\infty$}

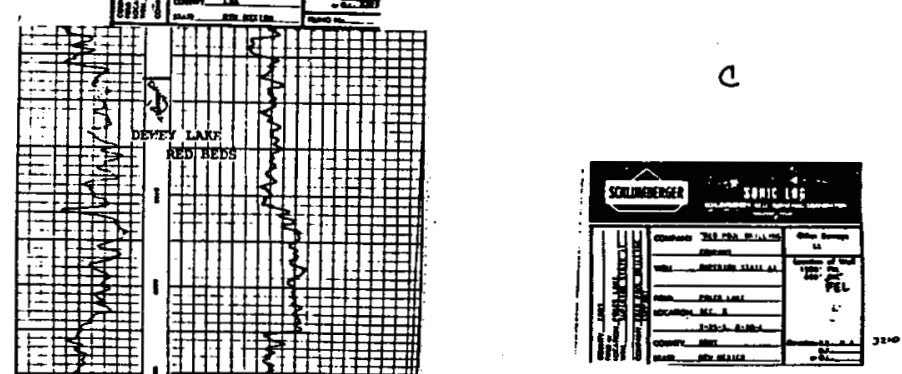

盗

(1) 1: $=1 m$ min (2) $11: \quad 1: 5$ $3 \div$ (I)

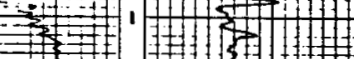

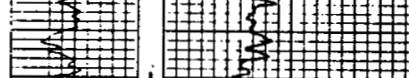
$+1$ (1)

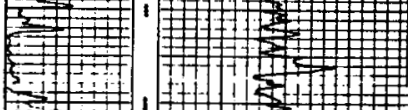
(㓋)

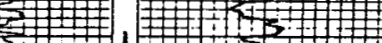

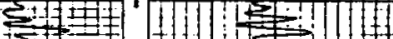
(1) (1) . (I) (1) 葏 3 1 (1) 5.i (1) (1)

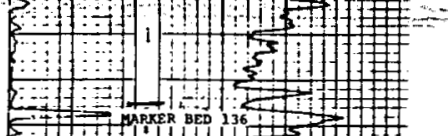

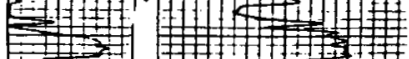
—

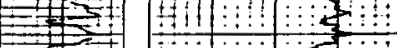
$\div, 11 \ldots$ Dan $1+{ }_{11}$

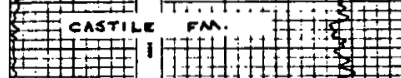
肃 ¿11 1 ( (II) ¿ -

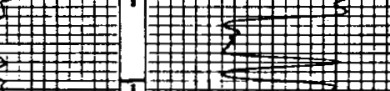

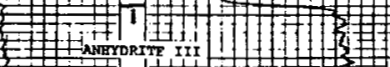
-

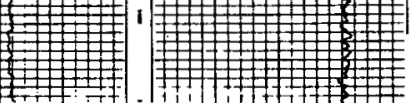
进1

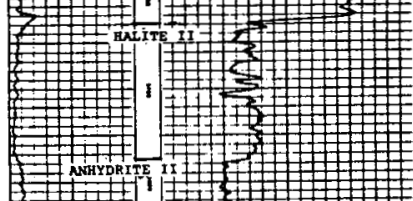

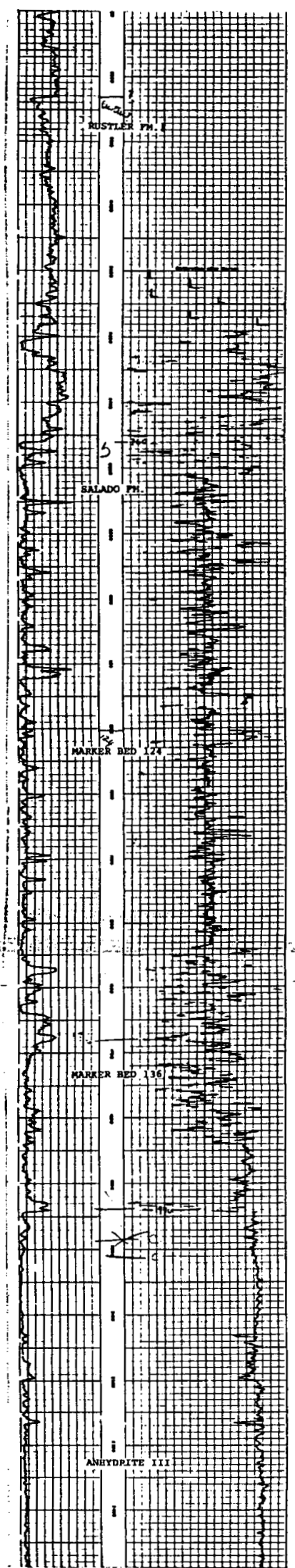




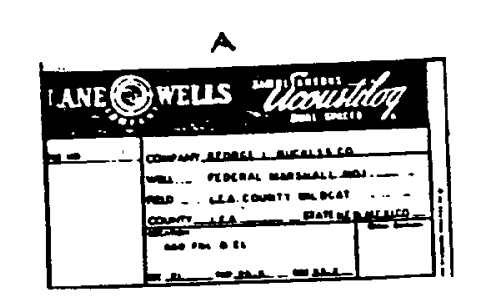

世地

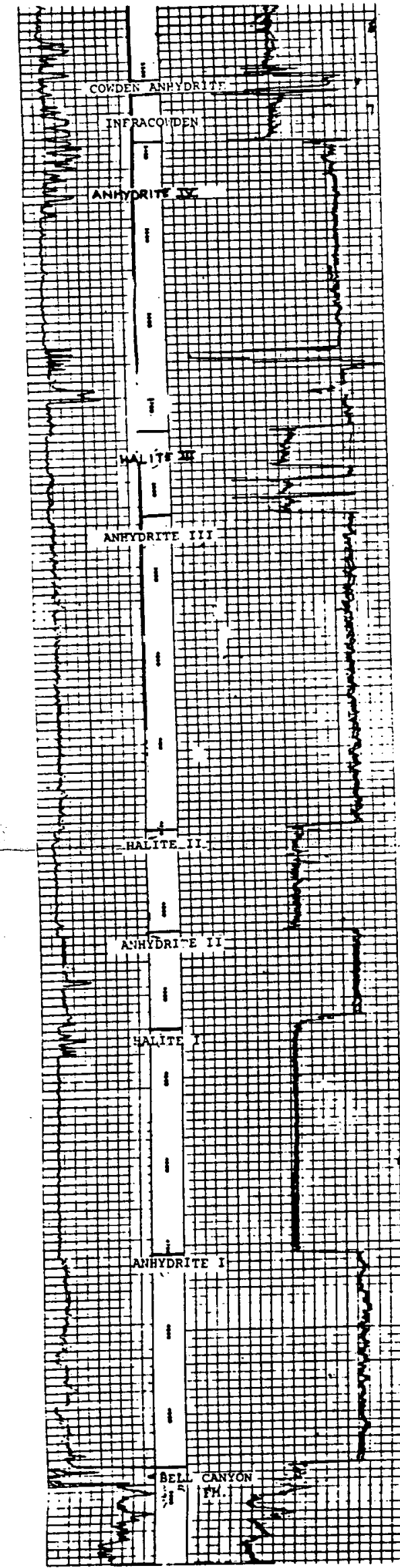

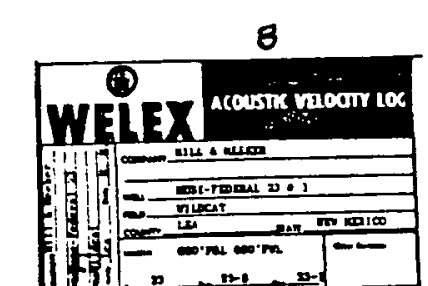

(5)

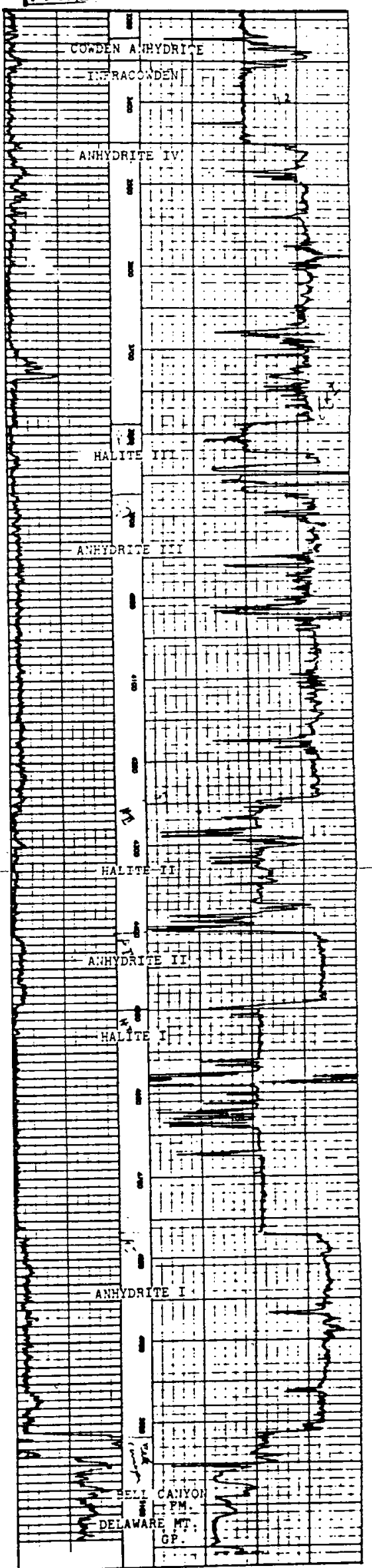

Figure 29. Comparison of ideal and nonideal logs of the lower Salado and Castile stratigraphy. (Ideal complicated in the right-hand log. AIII and anhydrite bed in HI.) 
With regard to the first assumption, these logs are not necessarily straightforward to interpret. Such difthe deviation of the log signature from the ideal. These ambiguities are greatest for the Lower Salado (MB 136 and below) and Upper Castile (above Halite II). (1983) is recommended in which distinct markers such as MB 124 and Halite II are used.

The second basic assumption is lateral continuity of halites in the Upper Castile. This assumption precludes any syndepositional thickening and thinning and lateral facies variation (Anderson, 1981 and 1983). Thus, any observed thickening and thinning would be construed as the result of post-Permian deformation and/or dissolution. However, the inferred Poker Lake structures (see following sections) show the problems with this assumption. Within the cluster of four holes in Section 8, a thin halite bed that has been tagged in some logs as HIII can be traced at a consistent elevation but with variable thicknesses. ficulties are caused either by the quality of the log or For comparison of isopachs, the approach of Lambert

\section{Poker Lake Structures}

At first glance, the numerous industry exploration holes in the Delaware Basin seem to provide an excellent record for log correlation. However, the distribution of holes from which logs have been analyzed is not uniform. Of the 276 holes used in this report, large localized concentrations occur; e.g., in T25S R32E (see Figure 1). Hence, the structural detail cannot be extended with the same confidence from area to area. Early log interpretations in the Delaware Basin resulted in contour maps (e.g., Figure 4, Anderson, 1978 and Figure 30 in this report). This specific example of a Halite I isopach map is instructive. The map shows detailed contouring and a fabric that is imparted by the orientation of contour structures. However, the map detail is misleading since the synforms and antiforms are largely based on one-hole anomalies. The areal extent and fabric of the structures shown have been inferred and drawn in; the actual size of such structures needs to be carefully established. We will concentrate on the Poker Lake structures in T25S R30E to illustrate the problems of extrapolation of one-hole data.

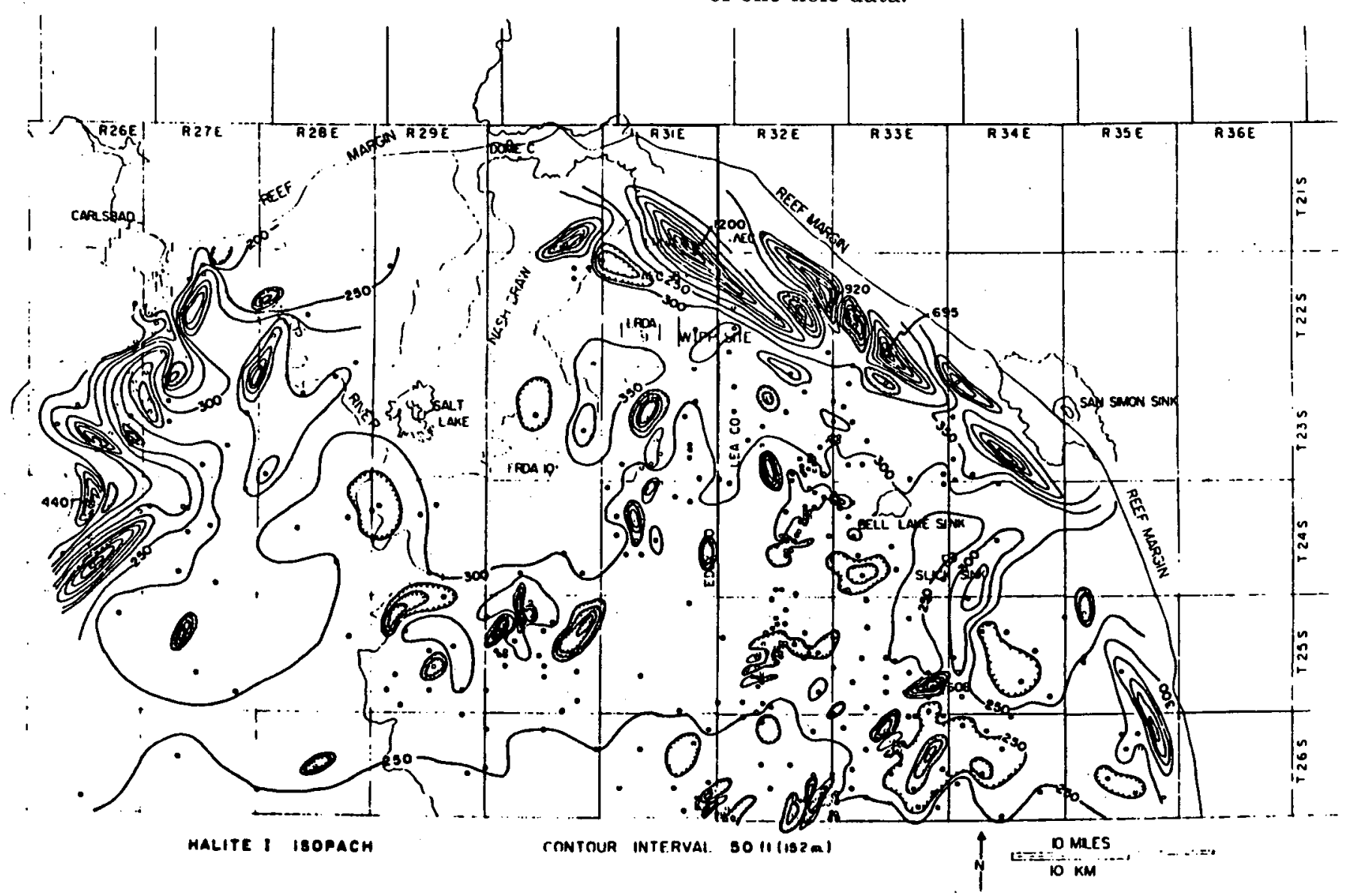

Figure 30. Isopach Map of Halite I in the northern Delaware Basin (from Anderson, 1978. Such maps can display a fabric and topography of structures that are indicated not so much by well data as by inference of expected geology. Hence, such fabrics may be misleading.) 
Poker Lake structures were shown as a N-Strending syncline-anticline pair by Anderson and Powers (1978). The contour maps in Anderson and Powers (1978 Figure 6, p 82) suggest an apparent N-S length for these doubly plunging structures of 15000 $\mathrm{ft}$, and an apparent $\mathrm{E}-\mathrm{W}$ width of $6000 \mathrm{ft}$ (Figure 31 in this report). Such inferred structures are curiously large when the detail of available boreholes is examined (Figure 32). The anticline-syncline pair is based on two holes, A05,2530 and PO8,2530, respectively. Within Section 8 , the synclinal node $(\mathrm{PO} 8,2530)$ is constrained by three other holes (LO8,2530, RO8, 2530 , and KO8,2530). These three holes are within $0.5 \mathrm{mi}$ north, east, and south of the anomalous hole (Figure 33). Horizons can be correlated with normal stratigraphy and structure within the Castile among the three bounding holes. Hence, the size of any synclinal structure is less than the spread of the boundary holes $(0.5 \mathrm{mi})$, and the existing structure is much less in areal extent than portrayed in the older contour maps.
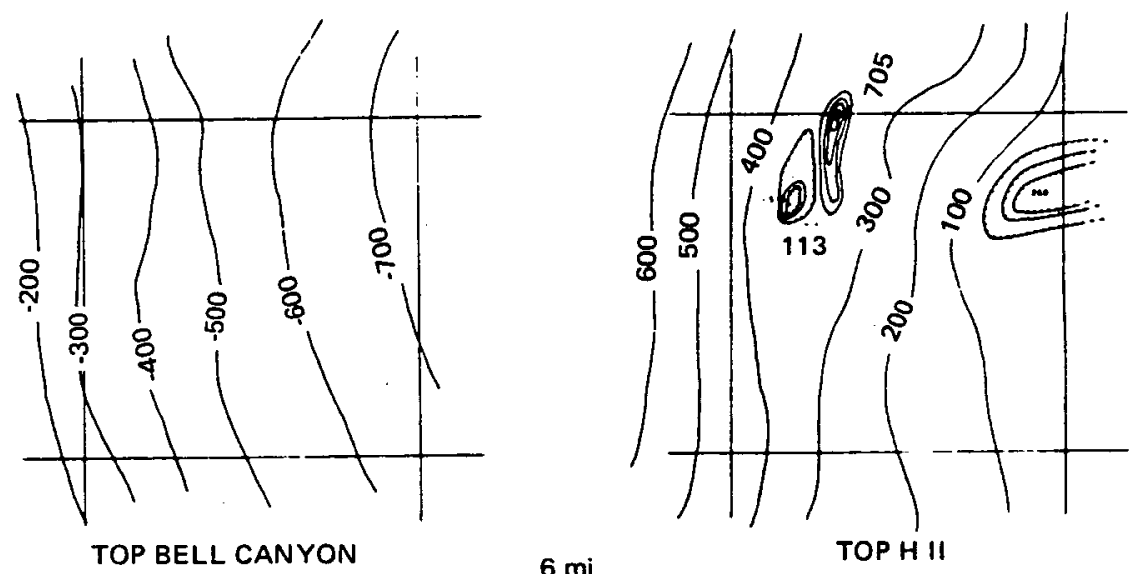

$6 \mathrm{mi}$

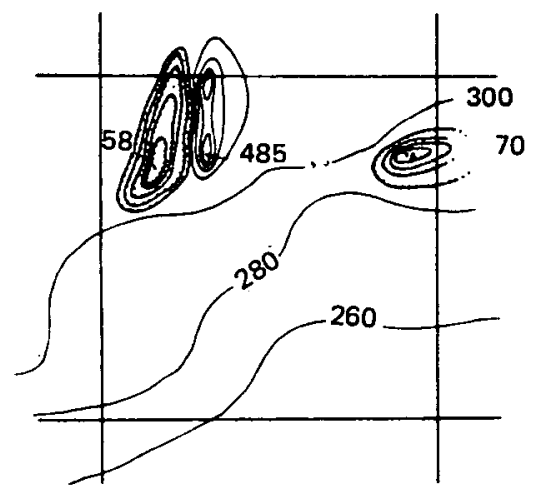

H I ISOPACH

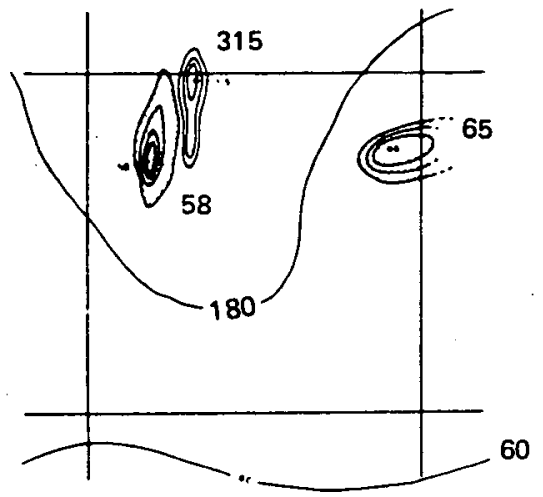

H II ISOPACH

Figure 31. Poker Lake structures (as shown in Anderson and Powers, 1978. The complete square outlines the township boundaries. Section 8 is astride the two structures in the northwest corner of the township.) 


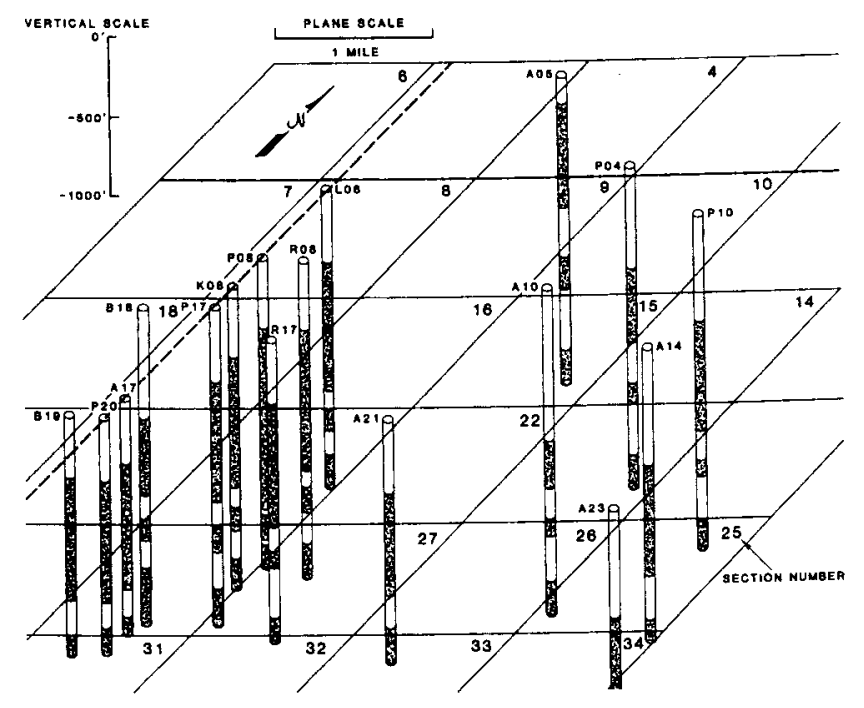

Figure 32. Oblique view of holes in Northwest corner of Figure 31. (This figure combines areal distribution with the stratigraphic picks in the Castile and lower Salado Formations. Stippled units are anhydrites; unpatterned units are halite. The uppermost stippled unit is the Salado and Anhydrite III combined across the Salado-Castile unconformity. The next lower unit, unpatterned, is Halite II. Below Halite II is the stippled Anhydrite II, etc. Dashed and bold lines are trace of cross sections in Figures 34 and 36. )

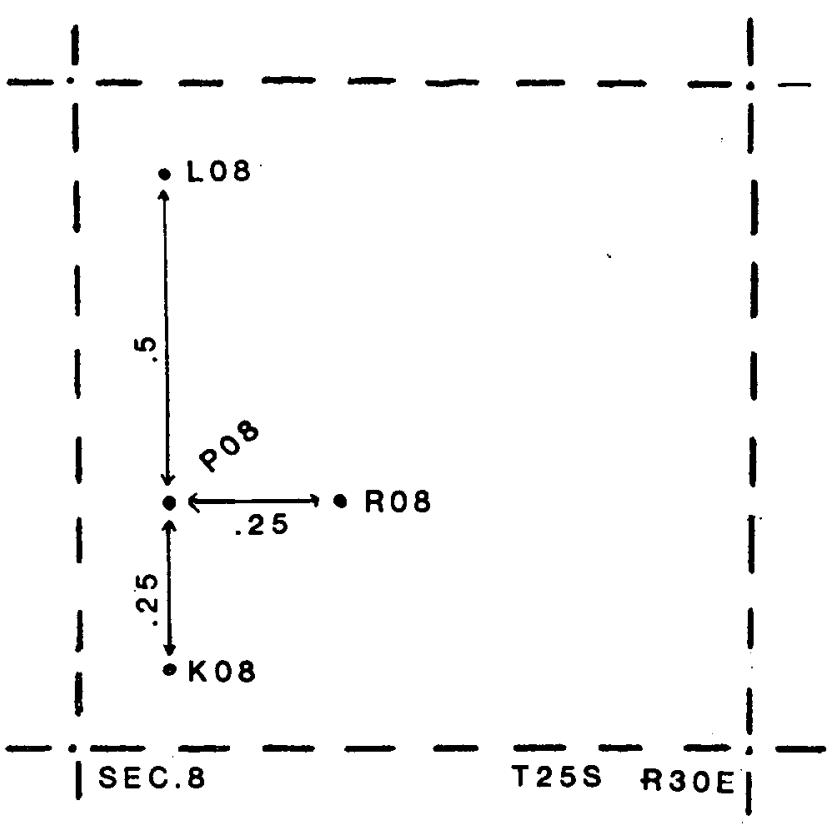

Figure 33. Detail map showing locations of Poker Lake boreholes in Section 8, northwest corner, of Figures 31 and 32

\section{Poker Lake Syncline}

Synclinal structures such as this one are most often taken as evidence of dissolution (Anderson, 1983; Davies, 1983). In their models, the synform is produced by removing salt through fractures that connect the Bell Canyon aquifers with the Castile halites, or through some as-yet-undiscovered aquifer in the upper Castile or Salado. Since the Poker Lake synform is the result of thinned Castile halites (see Figure 34), the former process would need to be the active one for dissolution to have occurred in this area. However, dissolution-caused downbuckling apparently does not affect the upper Castile and Salado (see Figure 34). This observation would suggest that the synform developed before the Permian deposition of the units above it.

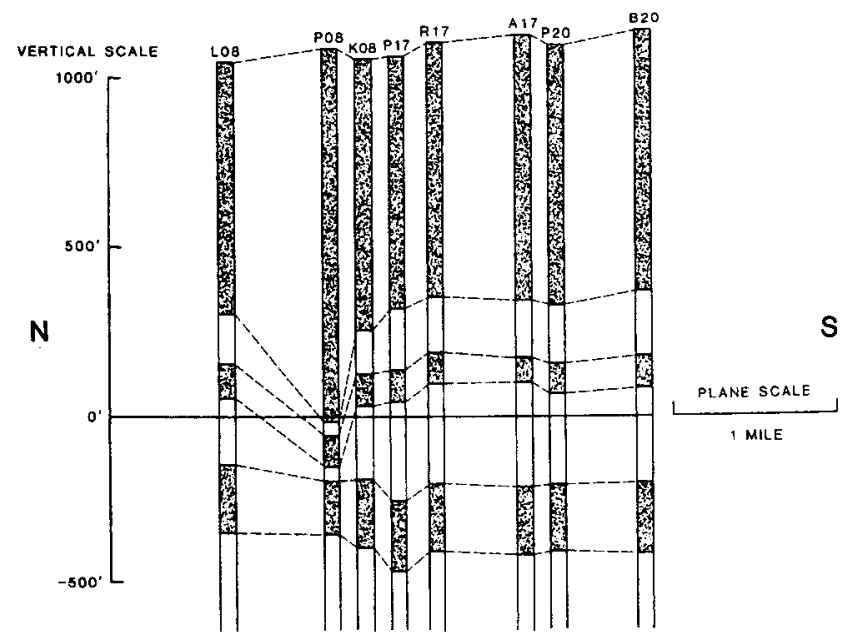

Figure 34. Fence diagram along a north-south line through the Poker Lake structures. (See Figure 32 for location of line and an explanation of units. Stippled pattern is anhydrite; unpatterned is halite.)

The evidence for this conclusion is that the upper anhydrite, Anhydrite III and lower Salado, in the center of the synform (PO8,2430), is level with or above the same unit in adjacent holes. The structural low could be interpreted as having developed by salt flowage or by sedimentary channel-cutting before deposition of the overlying anhydrite. Thickening of the overlying anhydrite was a compensation response to the downwarp of the deposition surface after deformation. 
A counterargument is that the nonbuckling of the upper anhydrite units in the synform is unreal and that the near equivalent elevation of upper anhydrite is coincidental. In this argument, the massive upper anhydrite masks downwarped Anhydrite III and Cowden layers in the synform. Hence, the synform extends upward but cannot be seen in this argument.
This type of conclusion, coincidental, can be disregarded if one observes the nearly level correlation of secondary markers in the upper Castile and the lower Salado between adjacent holes in the Poker Lake structures (Figure 35). Therefore, this very localized depression of mid-Castile surfaces is an example of snydepositional thinning related to salt flowage or to sedimentary channel-cutting or channel-dissolution. 


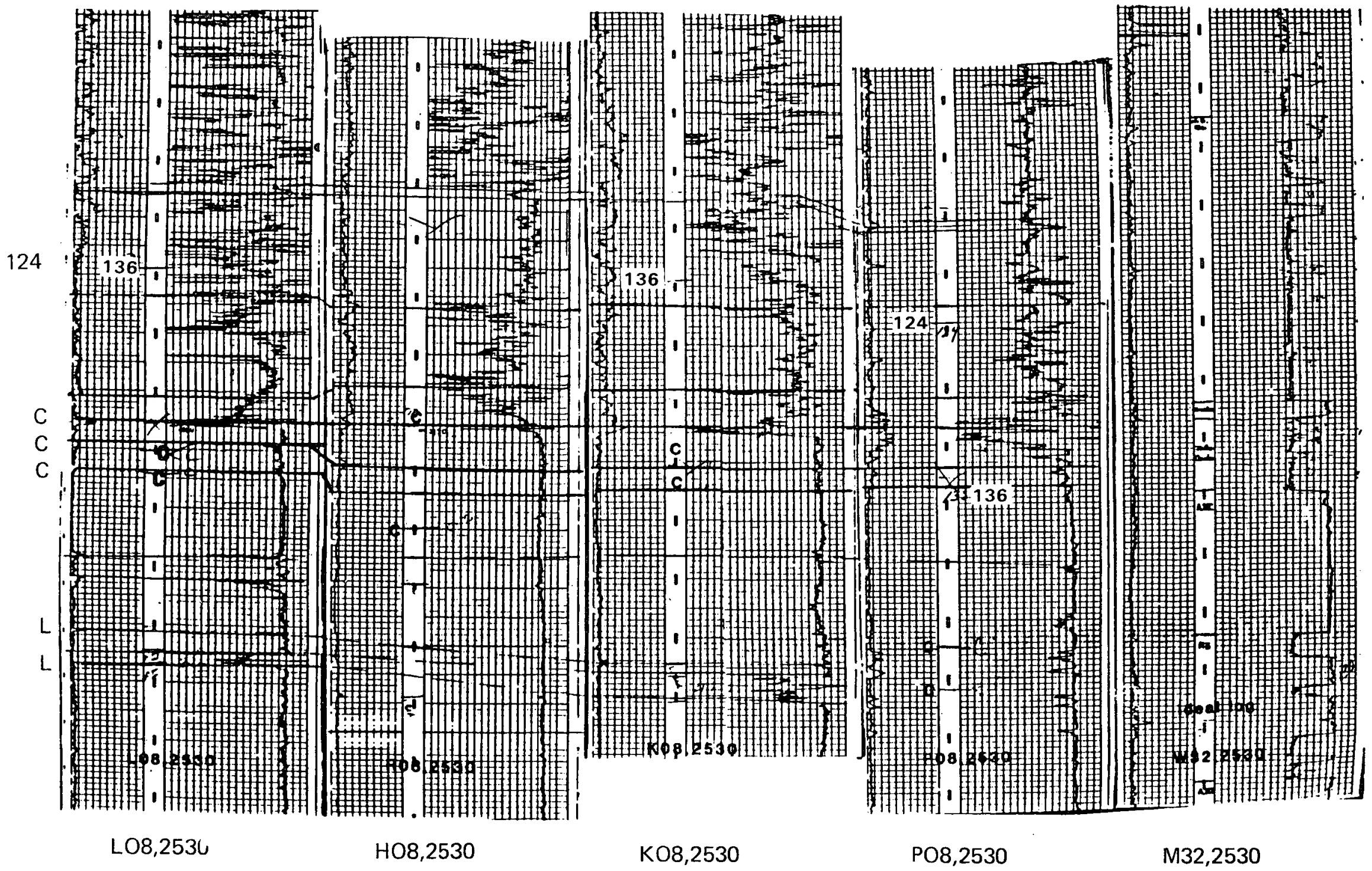

Figure 35. Detail of upper section of massive anhydrite from holes in Poker Lake structures (Lines indicate inferred continuity of distinctive markers. "C", "124", and "136" represent different stratigraphic picks made for the same unit by different workers, which again attests to the inherent ambiguity. Log on the far right (M32,2530) is an "ideal" log for comparison of thicknesses and position of markers.) 


\section{Poker Lake Anticline}

The second major structure in the Poker Lake area is the antiform (Figure 36). The significant difference between this structure and the Poker Lake synform is that the upper anhydrite is displaced in the antiform. Hence, deformation probably occurred after deposition of the units. Halite I and II are thickened relative to adjacent holes; Halite $I$ is the most thickened. This structure is typical of a salt-flowage structure as seen north of the WIPP site (Borns et al, 1973).

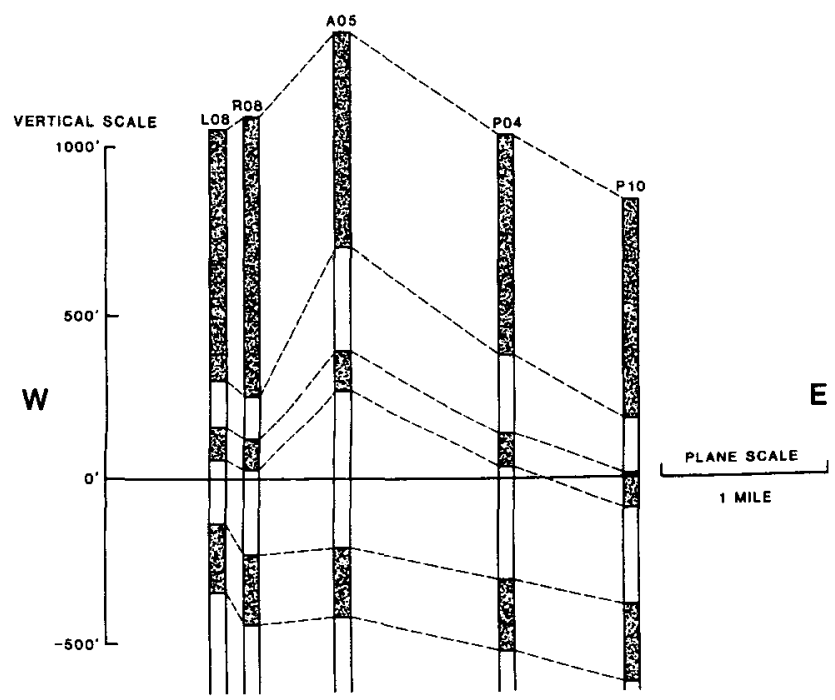

Figure 36. Fence diagram along an east-west line through the Poker Lake structures. (See Figure 32 for location of line and an explanation of units. Stippled pattern is anhydrite; unpatterned is halite.)

Another observation from the dense pack of holes in the Poker Lake area is that the upper surface of the DMG exhibits an uneven topography. Such irregularities can produce apparent flow or dissolution structures in the lower and mid-Castile. However, the depression on the sedimentary surface existed before and during deposition.

Examples have been provided above for (1) the misleading contour extrapolation for one-hole anomalies and (2) the ambiguous nature of certain stratigraphic picks. However, resultant maps (Anderson, 1978; Davies, 1983) have been used as compelling evidence for dissolution and other processes in the
Delaware Basin. In the case of the Poker Lake structures, the actual sizes of the anticline and syncline are significantly smaller $(6 x)$ in map view, than the structures extrapolated by Anderson (1978) and Anderson and Powers (1978). The remaining smaller structures (one-hole anomalies) can still be attributed to salt flowage and/or dissolution since the Permian.

\section{Disruptions of Ideal Stratigraphy}

The preceding example of the Poker Lake structures demonstrates the lateral variations in a stratigraphy from one hole to another in a closely spaced array. The sources of such variations can be deformation, dissolution, or lateral facies change. Deformation and facies changes such as the Salado-Castile unconformity cannot be detected from individual well logs. We infer such structures by regionally comparing logs and following distinctive units through lateral correlation. In this step, log ambiguity is the greatest hazard.

Figure 37 shows the conceptual effects on $\log$ signatures of the Salado-Castile unconformity and selective dissolution in the upper Castile and Lower Salado. Anderson (1983) has argued that the stacking of anhydrite residues can produce an apparently compensated thickness of anhydrite across the unconformity. The massive anhydrite signature would need to mask intervening residues after halite removal. The volume of halite that must be removed to create the stacked effect should probably create residue zones of an extent that would be hard to mask. From Figure 37, we see the feasibility of the apparent thickening by dissolution and collapse. However, the compensation of thickness for Castile thickening and thinning can only be fortuitous. Some depression of a marker bed surface would probably be observed and would reflect the mass removal of halite only if removal were post-Permian.

The arguments above have depended on log-to-log comparison. Within an individual $\log$, dissolution breccias or residues may be detected by rapid oscillations in the log signature as corroborated by Nash Draw core (Lambert, 1983). One needs to be careful that such oscillations are not merely the result of amplified background when the log sensitivity is relatively high. 

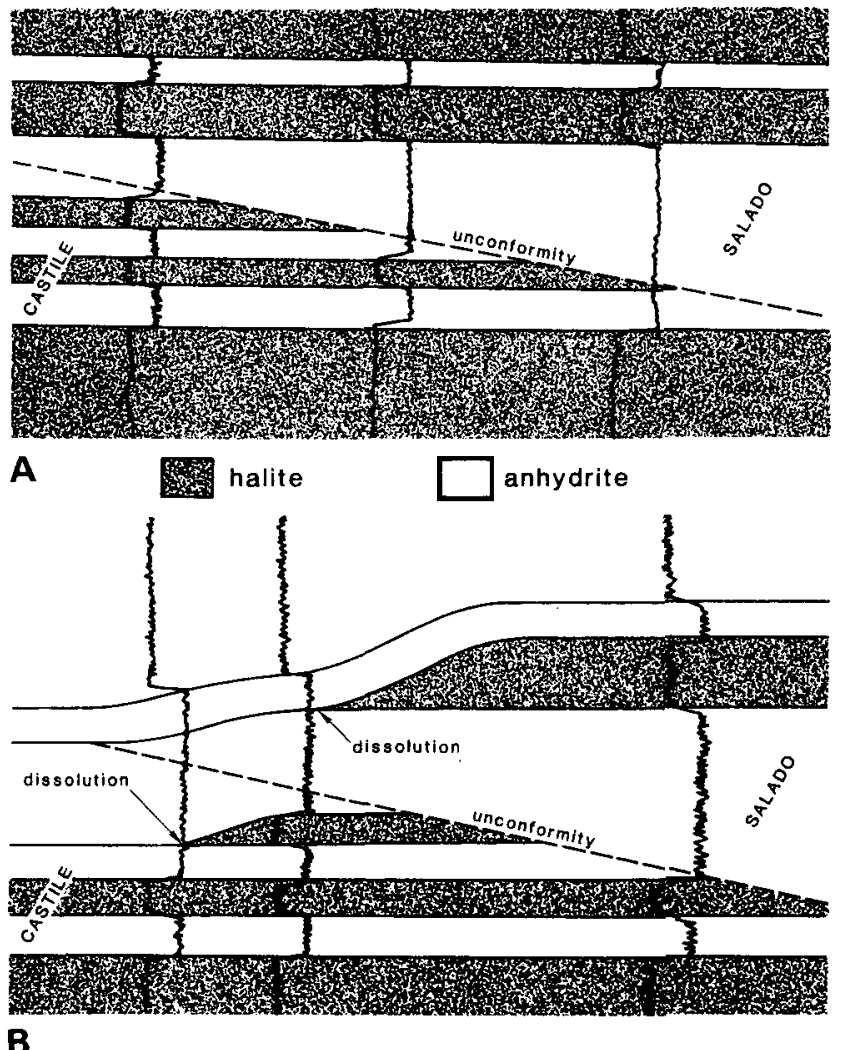

Figure 37. Idealized effects of (A) Castile-Salado unconformity (Anderson, 1983) on acoustilog (similar on Sensilog or Sonic Log) (Note thickening of anhydrite signature.); and (B) selective halite dissolution in addition to unconformity. (Thickening of anhydrite occurs, but marker surfaces do not remain level.)

\section{Conclusions}

Regional log correlation remains our most useful tool for determining the regional stratigraphy and structure in the northern Delaware Basin. Because interpretation cannot be based on inferences from single logs but needs regional log-to-log correlation, we need to continuously update our data base. The basic conclusions will remain the same, but as coverage increases, current ambiguities will decrease. Current $\log$ correlations suggest the following:

- The Castile is characterized by thickening and thinning. Hence, mass redistribution rather than mass removal is the dominant process.
- Thinning in some lower Castile structures was compensated for by thickened upper Castile and lower Salado sedimentation. This relationship suggests that the synform existed during Permian (Ochoan) sedimentation.

- Irregular topography in the top of the Bell Canyon can produce apparent structures in the overlying Ochoan units.

Anderson (1978, 1981, 1983) has proposed deep dissolution as a major mechanism of salt removal in the northern Delaware Basin. He suggested that dissolution was marked in two zones, which are linear series of sinks. One zone trends SSE from the Poker Lake structures with a linear extent $>30 \mathrm{~km}$; the other zone, which includes San Simon Sink, is a line of troughs overlying the Capitan Reef on the eastern side of the basin. The northern end of Anderson's dissolution structure appears in the southwestern corner of the area covered in Figures 3 through 26. This zone is $20+\mathrm{km}$ SSW of the WIPP site. It is conceivable that this set of troughs was caused by dissolution, although the mechanism may not be deep dissolution but dissolution related to the ancestral Pecos River (Bachman, 1983). At the scale of resolution for the spacing wells, no continuation is observed of this structure NNE towards the WIPP site.

Locally, Davies (1983) has proposed that finger sands within the Bell Canyon control dissolution; such finger sands have higher transmissivities than do adjacent rock types. These finger sands trend NE. Structure contours do not reflect these sands; nor, in fact, do Anderson's line troughs. Davies has also proposed that a structural depression in the mid-Salado is evidence of deep dissolution two miles north of the WIPP site center as marked by the contour maps of Snyder in Borns et al (1983). The size of this structure is such that it does not appear on maps based on hydrocarbon industry holes. However, DOE has proposed to drill this structure to investigate its origins.

Lateral dissolution within the Rustler has occurred $\sim 15 \mathrm{~km}$ west of the WIPP site as marked by Nash Draw. Within this $15-\mathrm{km}$ radius, there is no compelling evidence for deep dissolution. 


\section{Bibliography}

Adams, J. E., "Upper Permian Ochoa Series of Delaware Basin, West Texas and Southeastern New Mexico," Am Assn Pet Geol Bull, 28:1596-1625 (1944).

Anderson, R. Y., Deep Dissolution of Salt, Northern Delaware Basin, New Mexico, Report to Sandia Laboratories, 1978.

Anderson, R. Y., and D. W. Powers, "Salt Anticlines in Castile-Salado Evaporite Sequence, Northern Delaware Basin," in Geology and Mineral Deposits of Delaware Basin and Adjacent Areas, New Mexico Bureau of Mines and Mineral Resources, Circular 159, pp 79-84, 1978.

Anderson, R. Y., Deep-Seated Dissolution in the Delaware Basin, Texas and New Mexico, Spec Publ No. 10, New Mexico Geol Soc, pp 133-145 (1981).

Anderson, R. Y., Evidence for Deep Dissolution in the Delaware Basin, Report prepared for the State of New Mexico Environmental Evaluation Group, April 1983.

Bachman, G. O., Regional Geology of Ochoan Evaporites, Northern Part of Delaware Basin, New Mexico Bureau of Mines and Mineral Resources, Open-File Report 184 (1983, in press).

Borns, D. J., L. J. Barrows, D. W. Powers, R. P. Snyder, Deformation of Evaporites Near the Waste Isolation Pilot Plant (WIPP) Site, SAND82-1069 (Albuquerque: Sandia National Laboratories, 1983):
Davies, P. B., Assessing the Potential for Deep-Seated Salt Dissolution and Subsidence at the Waste Isolation Pilot Plant (WIPP), prepared for the State of New Mexico Environmental Group Conference "WIPP Site Suitability for Radioactive Waste Disposal," May 12-13, 1983, Carlsbad, New Mexico.

Griswold, G. B., Site Selection and Evaluation Studies of the Waste Isolation Pilot Plant (WIPP), Los Medaños, Eddy County, New Mexico, SAND77-0946 (Albuquerque: Sandia Laboratories, 1977).

Jones, C. L., C. G. Bowles, and K. G. Bell, Experimental Drill Hole Logging in Potash Deposits of the Carlsbad District, New Mexico, USGS Open-File Report 60-84, 1960.

King, P. B., Geology of the Southern Guadalupe Mountains, Texas, USGS Prof Paper 215, 1948.

Lambert, S. J., Dissolution of Evaporites In and Around the Delaware Basin, Southeastern New Mexico and West Texas, SAND82-0461 (Albuquerque: Sandia National Laboratories, 1983).

Powers, D. W., S. J. Lambert, S-E. Shaffer, L. R. Hill, and W. D. Weart, eds, Geologic Characterization Report, Waste Isolation Pilot Plant (WIPP) Site, Southeastern New Mexico, SAND78-1596, 2 vol (Albuquerque: Sandia Laboratories, 1978). 


\section{APPENDIX \\ Well-Log Data Arranged by Township, Range, and Section (all elevations in feet)}

Example Entry

Hatmesa 2\#2/Phillips Pet. Co

H11, 2132, 3861

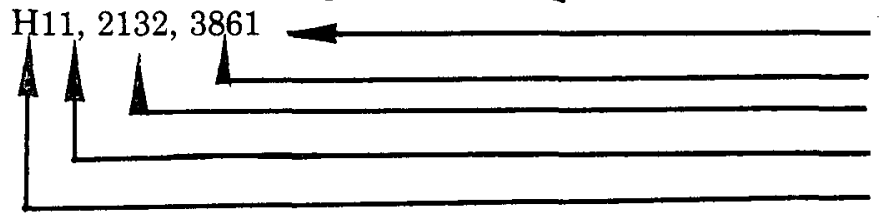

alpha identification

Applicon identification text (id), ground elevation in $\mathrm{ft}$ township and range section

well identifier

$1515,1948,2430,2855,3040,3060,-1,-1,3170,-1,-1,-1,-1,-1$

\section{Elevations}

1 Top of Rustler

2 Top of Salado

3 Top of MB 124

4 Top of MB 136

5 Top of Cowden

6 Top of Infra-Cowden

7 Top of Anhydrite IV

(in this case, -1 indicates that no pick was made)

8 Top of Halite III

9 Top of Anhydrite III

10 Top of Halite II

11 Top of Anhydrite II

12 Top of Halite I

13 Top of Anhydrite R

14 Top of Bell Canyon Formation 
FANAMEFILANFET, COR' . HIGEULYUNIT $\$ 18$

F $03,2129,3412$

$145,500,-1,-1,-1,-1,-1,-1,-1,-1,-1,-1,-1,-1$

JNIJNOIL/COI.OFCAL I \& . CUWOENFEIRAL 1

$404,2129,3471$

$200,-1,-1,-1,-1,-1,-1,-1,-1,-1,-1,-1,-1,-1$

MEAIICOFFUF, LTI . HAFIKISEELL $\$ 2$

$\operatorname{mos}, 2129,3468$

$445,740,-1,-1,-1,-1,-1,-1,-1,-1,-1,-1,-1,-1$

MEAICCFFOF - L.TU.HAFKISEELL 1

$805,2129,3472$

$250,555,-1, \cdots 1,-1,-1,-1,-1,-1,-1,-1,-1,-1,-1$

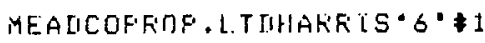

$105,2129,3487$

$825,1050,-1,1970,-1,-1,-1,-1,-1,-1,-1,-1,-1,-1$

FANAMER, FETCORFEISEELIIYUNIT 16

$F 18,2129.3309$

$150,450,-1,890,1250,1272,-1,-1,-1,-1,-1,-1,-1,-1$

F'HILLIFSF'E T COJAMES ' C'1

F $35,2130,3218$

$125,460,-1,1420,-1,-1,-1,-1,2200,2505,2712,2845,33001,3610$

F'HILLIFSFETCOHATIAESA' A' 1

HO2, 2132,3793

$1570,1980,-1,-1,-1,-1,-1,-1,-1,-1,-1,-1,-1,:-1$

SUFEFIONOLLCOO.GUUT.'H・COM

$610,2132, \$ 800$

$1448,1880,-1,-1,-1,-1,-1,-1,-1,-1,-1,-1,-i,-1$

HATMESA2 2/FHILLIFSFET.CO.

$H 11,2132,3861$

$1515,1948,-1,-1,-1,-1,-1,-1,-1,-1,-1,-1,-1,-1$

F'HILLTFSHATMESA 1

$M 11,2132,3834$

$1552,1970,2430,2855,3040,3060,-1,-1,3170,-1,-1,-1,-1,-1$

SKELLEY. OILCO. SALTLAKESO.UNIT $\$ 1$

$\$ 21,2132,3679$

$1055,1450,2240,2640,2990,3014,-1,-1,3320,-1,-1,-1,-1,-1$ 
GULFOILSANSIMON 1

$626,2132,3748$

$-1,-1,-1,-1,3194,3234,-1,-1,3324,-1,-1,-1,-1,5100$

UNIUNCAKBILEAEC?

$431,2132,3662$

$670,1010,1770,2158,2515,2535,-1,-1,2896,3110,3,310,-1,-1,-1$

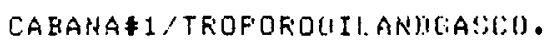

$T 01,2230,3357$

$315,630,1870,-1,-1,-1,-1,-1,-1,-1,-1,-1,-1,3800$

F'HILLIF'SFETCOJAMES $A^{*} * 1$

$M 02,2230,3193$

$163,560,1132,1520,1950,1962,-1,-1,2290,2675,2930,3057,-1,-1$

FHILLIF'SFE' , COJAMES $\cdot E^{\cdot} \$ 1$

I11 2230,3221

$275,650,1205,1578,1980,2000,-1,-1,2345,2420,2955,3065,3400,3665$

RICHAFISON\&EOSSTELEFALLEGG 1

$827,2230,3309$

$210,530,1455,1880,2250,-1,-1,-1,-1,-1,-1,-1,-1,-1$

CAMFANANO1/MCKNIBHTANITROFORO

$006,2231,3376$

$393,710,-1,1885,2160,-1,-1,-1,-1,3235,3390,3550,3710,3950$

STATE II $11 /$ SKELLEY

$505,2232,3623$

$1840,2285,-1,-1,-1,-1,-1,-1,-1,-1,-1,-1,-1,-1$

TEXACOETAL, BSHFEILFAL/RAYSMITHIIEILLINLCO.

$T 13,2232,3644$

$857,1275,2013,2405,2730,2757,-1,-1,3028,-1,3400,3595,4517,4853$

\#2REITANKUN I T/CARFERLRE ILL INGCO.

$[14,2232,3731$

$947,1290,2117,2605,3305,3350,-1,-1,3600,4342,4468,4430,4449,4780$

FELEFAL 1-17/CLEAFYFETKOLEUMCOR'F'

C17,2232,3701

$888,1200,2013,2568,-1,-1,-1,-1,-1,-1,-1,-1,-1,-1$

FELIRAL JENHINGS1-18/JUHINH. IRIGG

$T 18,2232,3696$

$900,1218,2010,2430,2550,267 \%,-1,-1,3178,3557,4037,4174,4408,4 \% 00$ 


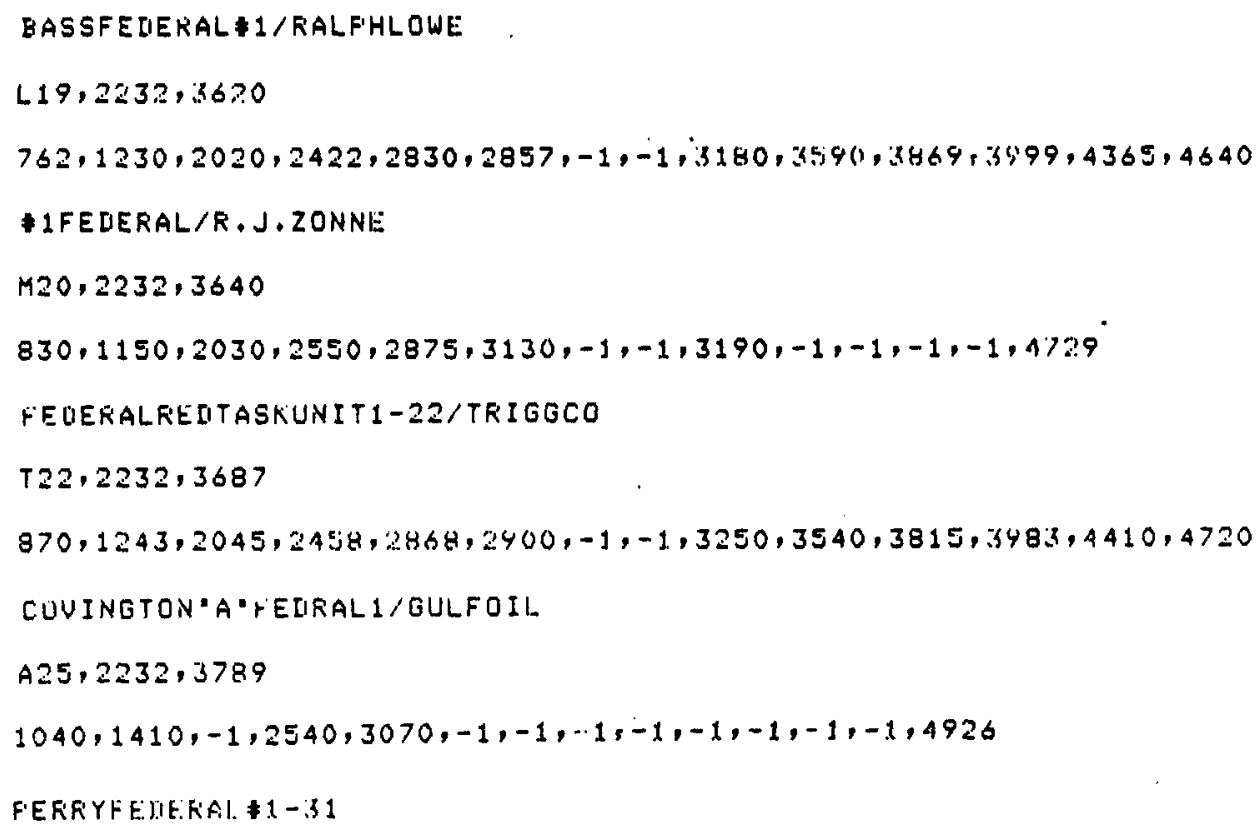


AFCOSTATE $\$ 1-16 /$ ELFASUNAT . LIAS

A $16,2331,3381$

$474,842,1606,2075,2750,2780,-1,-1,2810,3340,3530,3780,3910,4150$ MUSEFEDERAL $\$ 1 /$ F'ATOIL

$F \cdot 21,2331,3374$

$462,795,1638,2135,2685,-1,-1, .1,2725,3357,3547,3645,4000,4230$

TOIIII 2.3 FEIERAL 1 /TEXASAMER, OILCO.

$T 23,2331,3461$

$777,1090,1900,2362,2450,2968,-1,-1,3005,31563,3780,3810,4150,4327$ TOWDSEFEIERAL $\$ 1-2 /$ SKELLY

$525,2331,3506$

$663,1190,2015,2462,2960,-1,-1,-1,3050,3660,3780,4270,4378,4520$

TIIIIHEUERAL $26 \cdot N O \cdot 1 /$ TEX. AMOILCO.

$T 26,2331,3464$

$753,1062,1896,2374,2886,2925,-1,-1,2960,3570,3765,3864,4160,4385$ TDUD2GFEDIERAL $\$ 2 / T E X, A H$, OILCO.

A26, 2331,3454

$748,1065,1904,2376,2829,2842,-1,-1,2860,3570,3 / 63,3856,4150,4380$ WF' [GHT-FEIIRAL $\$ 1 /$ FATOILLOFF.

$4: 27,2331,3402$

$496,827,1663,2070,2679,2704,-1,-1,2733,3415,3615,3710,4024,4268$

MUEIL-FEQEHAL $\$ 1$ /ELFASONAT. GAS;

$1429,2331,3374$

$370,-1,-1,1880,2400,-1,-1,-1,-1,3170,-1,-1,-1,-1$

WRIGHT-FELERAL $\$ 2$

$w 33,2331,3392$

$420,808,1720,2207,-1,-1,-1,-1,2652,3380,3576,3672,3453,4169$

$0, B . K I L L J R, F E I I E R A L \neq 1$

$\kappa 03,2332,3727$

$1150,1580,2308,2717,3142,3165,-1,-1,3400,3767,4045,4168,4606,4875$ MCEEEOILCO, CONTINENTALLFDERAL $\$ 1-9$

$1409,2332,3699$

$1139,1540,2283,2708,3207,3250,-1,-1,3480,4024,4163,4280,45,10,4725$

HILL \&MEEKEF ZAMBASSALIUSUILCUR'. MYTHEWS'1.1'

$H 11,2332,3728$

$1195,1680,2440,2860,3315,3350,-1, \cdots 1,3623,3477,4210,4330,4610,4930$ 
JOHNH. TRI GGGELERALCONTINENTAL $1-15$

$115,2332,3722$

$1177,1638,2377,2795,3233,3260,-1,-1,3468,3950,4190,4300,1670,4928$

KIFKLINURILI.INGCO.FEIIEKALEST . 11 AF - 1

$\kappa 20,2332,3697$

$1210,1511,2273,2718,3278,3314,-1,-1,3315,34501,4156,4250,4561,4803$

H, L , JOHNSTONE, SR , CIJNOISO - F IELUSFEDERAL 1

$H 24,2332,3720$

$1225,1705,2476,2928,3453,3486,-1,-1,3628,4126,4357,4460,4770,6036$

CONTINENTALUII. COFEIIERALLF IELIIS\$1

$024,2332,3725$

$1235,1722,2506,2946,3415,3510,-1,-1,3610,4111,4342,1451,4795,5654$ H.L. .IUHNSTONSF . WEHRLI I FE.DE.FAL 1

J) $25,2332,3720$

$1215,1695,2469,2910,3380,3411,-1,-1,3565,4092,4309,4415,4 \% 69,5021$ CONTINEHTALOILCOFIEIMSNO. 2

$C 25,2332,3700$

$1210,1680,2470,2913,3450,3484,-1,-1,361 \%, 4155,4356,4460,4767,5013$

F' M. IIRILLINGCO, FEIIEFAI_F XELL I +1

$F \div 26,2332,3658,5$

$1210,1636,2424,2885,3407,3442,-1,-1,31553,4104,4311,4414,4610,4933$

F.M. IRILLINGCOFE.HIKALL IAMCS $\$ 4$

$526,2332,3705$

$1215,1680,2458,2900,3428,352 \%,-1,-1,3607,4145,4350,4457,476 \%, 5013$

MAXWILSONCINTIINENTALFEDEFFAL 1

$w 28,2332,3684$

$1180,1530,2321,2778,3300,3328,-1,-1,3432,4010,4205,4305,4586,4828$

CURTISHANKAMEFHOLIERFEIIERAL 1

$[33,2332,3666$

$1200,1520,2520,2890,3285,-1, \cdots 1,-1,3356,3980,4446,4530,4610,4846$

UNIONOILOFCALIFORNIAFEDERAL'L'NO. I

$434,2332,3624$

$1170,1480,2315,2796,3362,3390,-1,-1,3406,4020,4203,4336,4658,4993$

THEF'UREOILCOFE IERAL. 'K゙'NU, 1

F. $34,2332,3630$

$1170,1508,2315,2795,3364,3395,-1,-1,3420,4050,4253,4356,4657,4892$ 
JOHHH. TRIGGFEDERAL "WI. " NLI. 2-35

$J 35,2332,3692$

$1202,1450,2483,2950,3476,3510,-1,-1,3590,4145,4356,4460,4744,4988$

F. M. INRILLINICA,FEIIERALFAYNEROI

$F \cdot 35,2332,3689$

$1194,1615,2435,2911,3443,3480,-i,-1,3550,4110,4311,4413,4693,4936$

F.M. OHILLIINICOFEIIERALFAYNE $\$ 3$

$[135,2332,3630$

$1180,1505,2332,2820,3376,3410,-1,-1,3456,4060,4260,4365,4650,4895$

F', M. IIRIIILLINGCO, F'AYHEHO. 2

$435,2332,3700$

$1216,1638,2445,2900,3437,3470,-1,-1,3560,4125,43 \% 6,4429,47 \times 0,4952$

F , M. DHILLINGCO.FAYPEFEDERALNIJ , 4

F35, 2332,3663

$1200,1566,2385,2850,3390,3420,-1,-1,3440,407 \%, 4280,4373,4670,4914$

FUREOILBRIHAENSTOOL.UE.F.FUNT $\$ 1$

B.36, 2332, 3689

$1210,1680,2560,3080,3515,-1,-1,-1,3600,4160,4370,4475,4780,5025$

IIAUIIIFASKENGULFSTATE $\neq 1$

$636,2332,3664$

$1210,1670,2500,2965,3520,3550,-1,-1,3610,4180,4370,44 / 5,4755,5000$ FENFOLOTLLOHFTRISTESTATE\$1

$F \cdot 36,2332,3675$

$1200,1668,2480,2950,3510,3542,-1,-1,3605,4170,43 \% 0,4478,4767,5(13$ CABEENEXF, CUFF, CONTINENTALFE $1,+1-F^{\circ}$

$\operatorname{co4}, 2333,3636$

$1160,1655,2430,2840,3235,3270,-1,-1,3585,3445,4430,4625,4820,5110$ WM. H. \&EDWAELIR + HUISUNSHEILLFH HEKAI. 1-6

T06, 2333,3704

$1260,1770,2535,2970,3365,3400,-1,-1,3650,4055,4290,4405,4750,5030$

W. A. \&EDWAKDHUIDSONFE. LIT. FAL TWELL 1

$H 07,2333,3722$

$1270,1760,2515,2950,3405,3440,-1,-1,3690,4075,4325,4440,475,5,5025$

F-MOILCOMFANYTEXACOSIATE 1

$117, .7333,3715$

$1270,1775,2548,2985,3425,3460,-1,-1,3710,4150,4375,4490,4825,5100$ 


\section{TENNECOUJI.CUMF'ANYSKELLYSTATE 1}

$T 18,2333,3726$

$1290,1790,2550,2980,3415,3450,-1,-1,3690,4105,4335,4450,4780,5050$ HELEINGANIIFOIIFECHAN\#IASHEI.LSTAIE.

$518,2333,3722$

$1230,1715,2245,2870,3365,3400,-1,-1,3600,4025,4265,4380,4770,5025$ COHT INENTALOILCOMARSHALL $\$ 3$

$M 19,2333,3711$

$1230,1730,210,2965,3420,3455,-1,-1,3630,4140,4375,4485,4815,5075$ AMEF, QUASAREFINNINSTOUL 1

$A 20,2333,3713$

$282,1790,25,73,3090,-1,-1,-1,-1,-1,-1,-1,46,70,4870,5125$

LEUICKFEIIERAL 1

$[20,2333,3701$

$1280,1783,2570,3016,3485,3517,-1, \ldots 1,3777,4236,4459,4573,4890,6146$ LEASTATE 1

$k 31,2333,3696$

$1252,1762,2560,3012,3520,3559,-1,-1,3680,4241,4449,4552,4848,-1$

HUMELESTATE $\$ 1-32$

$H 32,2333,3667$

$1269,1772,2548,3011,352,3560,-i,-1,3698,4242,4449,4550,4848,5102$ STATE1-35

$835,2333,3654$

$1311,1807,2599,3050,3608,3642,-1,-1,3812,4353,4565,4671,4978,5246$

SHELLOILC.UANTELUFE.FIIIGEUNIT34-1

$534,2334,3490$

$942,1403,2282,2732,-1,-1, .1,-1,-1,-1,-1,-1,-1,-1$

FEIERALFEIII1/ELCAHITANUIL

$\varepsilon 06,2429,2984$

$230,-1,-1,-1,-1,-1,-1,-1,-1,-1,-1,-1,-1,-1$

CEDARCANYON9U1/SKELLY

$509,2429,2941$

$-1,-1,-1, \ldots 1,-1,-1,-1,-1,1730,2098,2295,2390,2690,2900$

MOBIL-FE CIERAL $\cdot 27 \cdot \neq 1 /$ FENNZOILU.I.

$127,2429,2924$

$450,695,-1,-1,-1,-1,-1,-1,-1,2183,2335,2427,2730,2947$ 


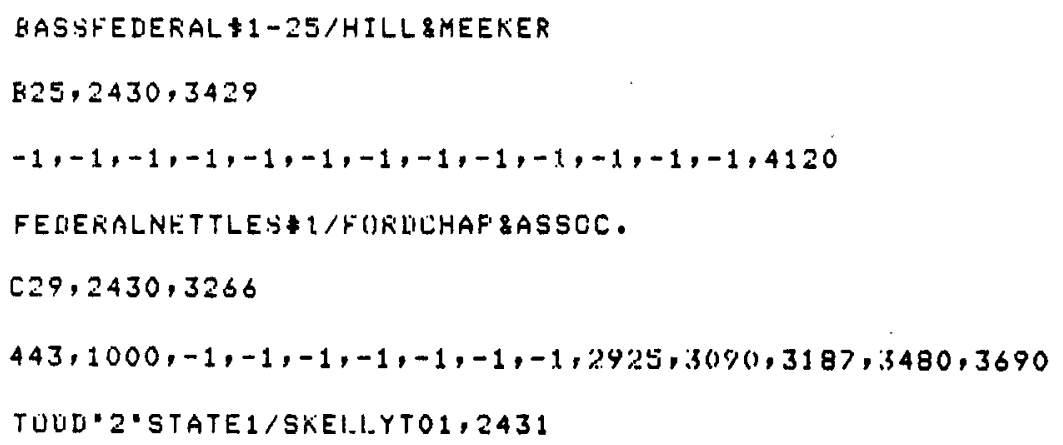


FUKEFLAKEUNIT\$36/FANAMFETR . CO.

$1128,2431,3502$

$590,-1,-1,-1,-1,-1,-1,-1,-1,-1,-1,-1,-1,4360$

COTTONIRAWUNIT $\$ 67 /$ TEXACO

$435,2431,3508$

$630,1012,-1,-1,-1,-1,-1,-1,-1,-1,-1,-1,-1,4410$

CUNTINEN TALFELIERAL I-L/CABEEN

$001,2432,3623$

$1160,1537,2370,2847,3409,3449,3467,3844,3863,4095,4295,4348,4 \% 10$, BONIUURANTFEDER:ALNOI/C. HANKAMER

4950

$H 06,2432,3584$

$888,1247,2078,2536,3100,3141,-1,-1,3403,3802,3996,4092,4417,4650$

OHIOSTATENO. $1 \% \mathrm{~F} \cdot M \cdot \because$

$1402,2432,3632$

$1170,1531,2370,2342,3386,3424,3460,3473,347 \%, 4085,4 \% 88,4390,4681$

FEIERALHANALIANLII/UUL F

$1 ; 10,2432,3628$

$1088,1394,2262,2750,3297,3336,-1,-1,3372,3998,4193,4297,4600,4832$

FEIIERAL HANAGANII\$3/GUL.F

$H 11,2432,3637$

$1172,1503,2408,2916,3415,3453,-1,-1,3470,4093,4291,4391,4585,4926$ WIMEERLY Y $12 \$ 1 /$ CONTINENTAL

$w 12,2432,3590$

$-1,-1,2437,2913,3434,3473,-1,-1,3480,4105,4307,4408,4673,4910$

HANAGANFE[IEFALNI] $3 /$ C. HANKAMER

$112,2432,3605$

$1130,1497,2352,2841,3381,3409,-1,-1,3480,4068,4259,4358,4570,4410$ WI MEERLY*12・2/CUNTINENTAL

$12,2432,3600$

$1203,-1,-1,-1,-1,-1,-1,-1,-1,-1,-1,-1,-1,4733$

\$ IUSAJENIYINGS/TENNECO

$114,2432,3628$

$1132,1446,2394,2880,3341,3409,-1,-1,3470,4074,4259,4359,4629,1874$

WOOLLEY 1 /WESTAIESFET, COFF , OFTX

$w 13,2432,3586$

$1188,1502,2364,2870,3434,3473,-1,3700,3 / 80,4174,4368,4463,473 ?, 4 \mathrm{mo}$ 
U.S.A.JENNINGSNO2/TENNEC.D

$114,2432,3588$

$1122,1434,2308,2805,3298,3352,-1,-1,3410,4076,4257,4356,4618,4858$ USAJENNINGS $3 /$ TENNECO

$U 14,2432,3624$

$1142,1452,2362,2850,3355,3392,-1,-1,3450,4050,4253,4354,46 \% 0,4910$ JENNINGSFEDERAL 4/TENNECO

$F 14,2432,5591$

$1130,1455,2386,2872,3318,3360,-1,-1,3430,4070,4256,4356,4624,4366$ FE [IEFIALHANA:IAN" $\mathrm{B}^{\cdot}+3 /$ GIILF

$G 15,2432,3591$

$1110,1428,2299,2777,3263,3343,-1,-1,3420,4018,4210,4308,4 ! 80,4610$ FE DIERALHANALIAN' 'B' +1 / GULF

$H 19,2432,3622$

$1050,1397,2252,2770,3240,3275,-1,-1,3390,4040,4223,4220,4596,4822$ FE[I. HANAGAN'B' $\$ 2 / G U L F$

$515,2432,3606$

$1122,1439,2375,2897,3294,3348,-1,-1,3440,4079,4257,4353,4612,4848$ HICKS-FE[IER:LL 1 /TENNECO

$T 15,2432,3602$

$1026,1338,2188,2700,3229,3310,-1,-1,3340,3996,417 \%, 4272,45 \%, 4803$ U. S. SMELTINIOUSA IITENNESSFE

$122,2432,3602$

$1066,1381,2275,2866,3241,-1,-1,-1,3241,4070,4248,4446,4586,4419$

USSMELTINGUSA 2 ITENINECO

$622,2432,3618$

$998,1311,2193,2743,3272,3340,-1,-1,32,2,4061,4236,4333,4524,4303$ USSMELTINGUSANOZ/TENNECO

$522,2432,3607$

$1060,1375,2280,2808,3370,3453,-1, \cdot 1,3370,4137,4309,1406,4623,4354$ USSKELTINGUSA 4/THNNECO

$\mathrm{U} 22,2432,3604$

$1063,1380,2290,2853,3311,-1,-1,-1,-1,4117,4288,4385,4608,4840$

USSMELTINGUSANOS/TENNECO

$122,2432,3592$

$1056 \cdot 1361,2252,2772,3384,-1,-1,-1,3384,4132,4308,4402,4632,4868$

BFADLEY $\$ 1, C, B, F E A D$

$\mathrm{H} 22,2432,3608$

$1052,1369,2268,2816,3348,3436,-1,-1,3348,4104,4278,4474,4620,4650$ 
$B R A I L E Y \neq 2 / C, B . R E A I$

$622,2432,3604$

$1072,1400,2296,2867,3350,3432,-1,-1,3500,4132,4292,4289,4627,4865$ ERNESTFEDERAL $1 /$ C. HANKAKER

$\varepsilon 23,2432,3609$

$1093,1413,2320,2888,3320,-1,-1,-1,3320,4129,4297,4392,4638,4873$

BUNDUURANTFEUERALINOI/OSBOFINETAL

$024,2432,3584$

$1130,1454,2344,2861,3370,-1,-1,-1,-1,4146,4425,4422,4698,4432$

COTTUNDRAWUNITWELL $\$ 72$, IENNECO

$[133,2432,3510$

$830,1144,2010,2545,-1,-1,3106,3346,3515,3900,4091,4195,4490,4715$ COTTDNEIRAWUNIT\$69/TEXACU

$634,2432,3519$

$881,1188,2058,2589,-1,-1,3190,3470,3560,3446,1124,423(1,42 \cdot 12,4750$

FEIIERALLIELASIN\$1/S.W.RICHAKUSOH

R.35, 2432,3524

$907,1239,2109,2625,-1,-1,3254,3471,3635,4002,4179,458,4,4576,4302$ NE.WIANFEIIEK'AL $\$ 1 /$ HONDOLIEILLING

$1101,2433,3581$

$-1,-1,-1,-1,-1,-1,-1,-1,-1,4104,4302,4406,-1,4930$

BELLLAKEIJNITT/CINTINENTALOIL

$\mathrm{B01}, 2433,3625$

$1275,1800,2600,3075,3560,3595,3760,3795,3805,4250,4465,4580,4550$, GULFSTATENW\$1/HONEIULRYI.L ING 5140

GO6, 2433,3598

$1175,1610,2455,2930,3450,3495,-1,-1,3510,4125,4.525,4430,4710,4955$ GULFN,W. $\$ 2 / H O N D O N F I L L J N G C O$

HO6, 2433,3606

$1185,1630,2460,2930,3440,3485,-1,-1,3520,4125,4335,4440,4735,4480$ STATEQOQ\$1\%TOML. INIIRAM

$007,2433,3590$

$1185,1635,2470,2940,3475,-1,-1,-1,3515,4155,4350,4455,4720,4960$

STATE:Oי:2/TOML. INGKAAM

$107,2433,3603$

$1205,1580,2445,2930,3460,3500,-1,-1,3510,4145,4340,4445,4720,4965$ 
STATE'F+ $1 /$ TOML INGRAM

$T 07,2433,3636$

$1200,1645,2480,2955,3495,3540,-1,-1,3550,4180,4525,4480,4 \% 10,5010$

STATE\$1-7/GEOR'GE.W.RILEYJNC.

$807,2433,3547$

$1225,1620,2440,2930,3560,-1,-1,-1,3590,4260,4440,4545,4795,5040$

GULFSTATE\$7-2/DAUIIIFASKEN

$F 07,2433,3578$

$1190,1630,2460,2940,3480,3520,3530,3550,3655,4170,4360,4465,4755$,

H.M. STATEA, G. I/SUNFAYMIDICONTINENT

5000

$508,2433,3637$

$1210,1700,2520,3033,3580,-1,-1,-1,3645,4255,4450,4555,4343,5100$

HOLLANEI 1/BYAR IEENINETT

$813,2433,3598$

$1245,1780,2635,5150,3685,3725,-1,-1,3760,4385,4580,4590,430,5190$

HOLLY-STATE $1 /$ ROEEKTH, HOLT

$H 17,2433,3592$

$1210,1680,2505,3050,3550,3600,-1,-1,3610,4260,4465,4565,4850,6100$ STATELOWE \$1/TENNECOOIL

$117,2433,3554$

$1200,1540,2395,2915,-1,-1,-1,-1,-1,-1,-1,-1,-1,5045$

STATE'BE:2ONOL/CONTINENTALOIL

$620,2433,3540$

$1135,1495,2360,2885,3495,-1,-1,-1,3540,4195,4400,4500,4780,5020$

STATE $\$ 1, F$. R. JACKSON

$J 22,2433,3594$

$1215,1730,2790,3330,3630,-1,-1,-1,3745,4400,4600,4705,4480,5230$

SUNFIAYSTATE 1 / TENNECUOIL

$T 27,2433,3502$

$1185,1590,2520,3100,3630,-1,-1,-1,3665,4370,4540,4640,4400,5150$

STATE $\cdot A F^{\prime \prime} \neq 1$

$T 29,2433,3525$

$1146,1492,2390,2942,3480,3500,-1,-1,3554,4335,4500,4599,4749,5177$

CONTINENTALSTATE 1/KIFKLINIFILLINGCO.

$[30,2433,3557$

$1070,1410,2270,2790,3415,-1,3510,3660,3800,4205,4390,4490,4730,4970$ 
CONTINENTALSTATE $\$ 1$ / ALBERTIIAEKLEOF.

$631,2433,3524$

$1062,1385,2280,2840,3470,-1,3660,3 \% 20,3835,4 \% 20,4415,4520,4 \% 65,5000$

\$ILEAST • •GX"/GULF \&KIFKLIN

$k 36,2433,-1$

$1165,1695,2550,3135,3690,-1,-1,-1,3785,4105,4600,4710,4955,5215$

\$ IGERIIING/HANAGANFETROLELIM

$H O 1,2434,3447$

$-1,-1,-1,-1,-1,-1,-1,-1,3400,3,65,4110,4300,4415,-1$

FEIIERALQBEQ*1/SHELLOIL

$1104,2434,3567$

$1045,1545,2400,2905,3355,3395,-1,-1,3795,4115,4415,4550,4840,5130$

BELLI.AKEUNIT 14 /CINTINENTALOIL

$\cos , 2434,3619$

$1145,1695,-1,-1,-1,-1,-1,-1,-1,-1,-1,-1,-1,5140$

BELLLAKEUNITND. 3 /CONTINENTALDIL

$806,2434,3630$

$1240,1760,2550,303 \div, 3495,3540,-1,-1,3 / 30,4200,4422,4525,4870,5138$

HALLFE[IEFIAL $\$ 1$

$509,2434,3570$

$1130,1660,-1,-1,-1,-1,-1,-1,3800,4,30,4650,-1,-1,5230$

SUFEKIITFFELERAL $1-3 / J$. GLENNEENNET

$803,2529,2985$

$340,900,-1,-1,-1,-1,-1,-1,-1,2280,2455,2650,2870,3065$

SUFEFIOF $\$ 1-3 / J$, GLENBENNET

$508,2529,2921$

$-1,170,-1,-1,-1,-1,-1,-1,1490,2030,2350,2450,2555,2755$

SUFERI IOFFEUERAI.\$1/NEILH.WILLS

W08, 2529,2923

$-1,260,-1,-1,1280,-1,-1,-1,1330,2060,2230,2330,2645,2845$

CORFALUFAWUNIT $\$ 1 / M O B I L$

$M 14,2529,3118$

$550,890,-1,-1,1710,1840,-1,-1,3895,2480,2620,2716,3040,3,35$

SUFEFIUFFEIIEFALISNO1/J.GLENEENINETT

H15, 2529, 3041

$290,770,-1,-1,-1,-1,-1,-1,1660,2295,2460,2550,2858,3060$

COFFALIFAWUNIT $\$ 2 / M$ MEILOIL

$\omega 22,2529,30 \% 8$

$680,910,-1,-1,-1,-1,-1,-1,1580,2345,2550,2645,2425,3130$ 
NO.1-26SUFERIDFIELIERAL/ J. RI.ENNEENNET

$826,2529,3043,5$
$175,530,-1,-1,-1,-1,-1,-1,1705,24(5,2520,2720,3020,3215$

SUFERIUFFELIERAL 1-27/J. BLENNBENNET

$\mathrm{B} 27,2529,2990$

$120,360,-1,-1,-1,-1,-1,-1,-1,-1,2-124,2515,2795,3000$

FEIERTAL 1 /EHLLFETFOLEUM

$\mathrm{B} 29,2529,2936$

$-1,225,630,920,1280,-1,-1,-1,1435,2090,2265,2355,2640,2835$

CITIESSERUI:CEFEIIERAL 1/BELLFETROLEUM

$\mathrm{E} 30,2529,2945$

$-1,260,625,1135,1080,-1,-1,-1,1250,2060,2225,2320,2610,2805$

STATE $\# 1 / D . B . S C U L L Y$

$532,2529,3012$

$-1,195,-1,-1,1330,-1,-1,-1,1350,2155,2325,2425,2700,2695$

RIEFEIERAI. \$IFATOILCORF

$704,2530,3273$

$850,1220,1809,1992,2263,-1,-1,-1,2263,2958,3134,3248,357,3785$

SUFERIORSTATE\$1/REUFOOL.

$\mathrm{R} 08,2530,3210$

$233,760,1203,1684,1839,-1,-1,-1,1434,2646,2888,2995,348,3684$

FOKERLAKF $44 /$ KASSENT.

F' $10,2530,3317$

$779,1050,1688,2149,2425,-1,-1,-1,2425,3119,3299,3394,3710,3920$

POKERLAKEUNIT\$5X-1 A / ALAMD

A $10,2530,3282$

$900,1235,-1,-1,-1,-1,-1,-1,2660,3074,5254,3.453,3642,3850$

SHUGAFTFEDERIALNDI/CHOCTAU

$[12,2530,3371$

$973,1271,1963,-1,-1,-1,2350,2950,2059,3640,3 \% 05,3800,3859,4079$

FOKERLAKEUNII 10 A-SIALAHO

A $14,2530.3349$

$1237,1530,-1,-1,-1,-1,-1,-1,-1,3250,3550,3660,378 \%, 4010$

HERZOGFEQIERAL $+1 / F$, R. BASS

$F 17,2530,3230$

$1064,1433,1680,2014,-1,-1,-1,-1,2166,2410,3088,3183,3489,3671$ 
R\&EFEDFIAL $\neq 1 \% F$, LOUE

$M 18,2530,3192$

$1050,1204,1466,1742,-1,-1,-1,-1,2088,2835,3021,3116,3362,4554$

JENNINGSFEDERALNO + 1/P,R , EASS

B18, 2530,3186

$725,1072,1385,-1,-1,-1,2042,2334,2360,2797,2985,3082,3430,3531$

FOKERLAKEUNITNOZ8/CENTRALSTATE:S

F.19, 2530,3209

$-1,979,-1,-1,-1,-1,-1,-1,2100,2851,3023,3119,3400,3600$

FOKEFLLAKEUNIT\$O-2A/ALAMO

$A 21,2530,3252$

$1180,1374,-1,-1,-1,-1,-1,-1,2320,3010,3184,3282,3484,3791$

FOKERLAKEUNIT $9-A-5 /$ ALAMO

A23, 2530,3311

$1067,1280,-1,-1,-1,-1,-1,-1,2475,3220,3390,3486,3,55,3460$

F'DKEFLAKEUNIT\$8-A-4/ALAMO

$A 27,2530,3260$

$1127,1431,-1,-1,-1,-1,-1,-1,2140,3040,3270,3367,3625,3827$

\$1-3OSUFEFIOFIE[IEFAL/J.G.BENNET

$E 30,2530,3101$

$820,985,-1,-1,-1,-1,-1,-1,1950,2664,2837,29,30,3215,3411$

FICHAKIISONBHASSFEDERALNU1/II.FASKIN

$835,2530,3246$

$1120,1538,-1,-1,-1,-1,-1,-1,2340,3080,3250,3340,3600,3800$

COTTONDFAWUNITNOSS/TEXACO

$[102,2531,3476$

$732,1016,1604,2152,-1,-1,2767,3141,3240,3686,3757,3953,4128,4346$

FOKEKLAKEUNITY-A-3/ALAMIJ

$A 28,2531,3348$

$820,1124,1742,-1,-1,-1,-1,-1,3090,3420,3577,3676,3917,4184$

\# IIELBASINHELEFIAL/GOLII. . SANTAHA

$535,2531,3319$

$1322,1537,2260,-1,-1,-1,2498,3050,3192,3513,3665,3760,4012,4229$

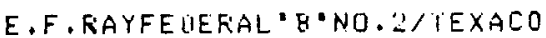

Fi $10,2532,3464$

$772,1141,1894,2465,3152,3384,-1,-1,3515,3874,4045,4146,4435,4662$ 
TENNESSEEGAS8OILCO/RAYUSA 1

$T 10,2532,3460$

$780,1120,1850,2420,-1,-1,3020,3405,3500,3350,4025,4125,4415,4640$

TEXACOE , F . FAYFEEIEFIALNCY $-1 \div 2$

F10,2532,3437

$795,1145,1895,2440,-1,-1,3055,3415,3510,3865,4040,4135,4440,4670$

EAILYFLINTFEYYUS $\$ 41 /$ TEXACODIL

E10,2532, 3470

$790,1140,1885,2445,-1,-1,3050,3405,3500,3860,4035,4235,4430,4655$

COTTONIFAUUNITNO4O/TEXACU

$[110,2532,3478$

$792,1120,1948,2536,-1,-1,3160,3419,3552,3915,4089,4134,4470,4 \% 7$

DOTTONERAWUNITNOZ9/TEXACO

C10,2532,3472

$786,1131,1908,2482,-1,-1,3077,3398,3624,3890,4070,4168,4128,4552$

TEXACOINC, COTTONIIFAWUNIT $\$$ S2

U10,2532,3468

$785,1145,1970,2470,-1,-1,3080,3445,3545,3885,4075,4175,4465,4695$

UNIONFEIIEFAL $\$ 1 /$ FATOIL

Fi $13,2532,3468$

$808,1137,1991,2513,-1,-1,3293,3439,3770,4122,4274,4373,4600,4834$

CONTINENTALFE[IEFIAL 1 / WESTATES

$411,2532,3409$

$837,1177,2014,2561,-1,-1,3090,3535,366 /, 4006,4180,4 \% 80,4,669,4412$

FELIEFAL $0 \cdot \$ 1 /$, I , ORNEILL, JR.

$F 14,2532,3445$

$761,1102,1923,2468,-1,-1,3163,3552,3691,4024,4212,4311,4545,4,70$

FEIIEFAL・ $0 \cdot \div 2 / \mathrm{J}$. IOQNEILL.

$014,2532,3454$

$788,1130,1980,2518,-1,-1,3300,3519,3711,4053,4210,4308,4562,4791$

ORAHALLFEDEFAL $14 \$ 1 / H I L L B M E E E F$

$H 14,2532,3455$

$773,1132,1882,2456,-1,-1,3210,346,5,3667,3,99,4166,4263,4489,4712$

TEXALOINC, G.E, JOFEANTELERAL\%NCT-1

$T 15,2532,3447$

$768,1138,1850,2453,-1,-1,-1,-1,-1,3426,4092,4185,4435,4661$ 


\section{G.E.JOREANFFIITNCT1 $\$ 2 /$ IEXACO}

$115,2532,3455$

$781,1143,1789,2318,-1,-1,3022,3206,5506,3450,4026,4126,4396,4622$

G.E. JOKLANFEDERAL\%NCT2 CWLLINO1/TEXACU

$F 15,2532,3451$

$787,1159,1830,2405,-1,-1,3080,3360,5550,3898,4064,4167,4385,4612$

G.E.JORIONFE[IERALZNCTZCNOZ/TEXACU

$615,2532,3455$

$792,1157,1842,2472,-1,-1,3124,3440,353,37884,4058,4158,4406,4623$

G.E. JOR [IAN $\$ 31$ TENNESSEE

$115,2532,3451$

$780,1142,1871,2440,-1,-1,3140,3428,3554,3902,4072,4171,4413,4637$

G.E. JORIIANUSA 2/TENIVESEE

$M 15,2532,3443$

$789,1164,1823,2395,-1,-1,3092,3377,3561,3911,4081,4178,4398,4623$

G.E. JORIIANUSA $\$ 4 / T E N$ NESSEE

$115,2532,3441$

$776,1139,1791,2341,2858,2888,3070,3346,3524,3869,4011,4140,4378$, COTTONIIEAW-UNITNO4G/TEXX.LO

4602

$w 15,2532,3440$

$779,1148,1805,2343,-1,-1,3040,3187,3442,3885,4062,4159,4430,4653$ CONTINENTALSTATE 1/SHCRELIME

$x 16,2532,3443$

$768,1128,1792,2362,-1,-1,3050,3416,3406,3860,4022,4120,4366,4592$ STATEZ1O\$1/CONTINENTAL

$216,2532,3444$

$759,1129,1792,2380,-1,-1,3090,3436,3510,3863,4027,4123,4362,44,84$ SIATKE.L.BFAIILEY1/TENINESSEE

$B 16,2532,3444$

$763,1140,1811,2402,-1,-1,3088,3425,35,17,3865,4033,4130,4580,4606$ STATEBFALILEY $\$ 2$, IENNESSE:-

$F 16,2532,3458$

$766,1160,1839,2426,-1,-1,3100,3423,3518,3871,4034,4133,4402,4629$ STATEE,L. BFIAILEY $3 / T E N N E C O$

$T 16,2532,3434$

$742,1110,1753,2351,-1,-1,3050,3391,3483,3941,4005,4101,4931,4551$ STATEMONSANTO\$1/TENNESSEE

$116,2532,3439$

$769,1138,1781,2336,-1,-1,3073,3291,3507,3856,4030,4131,4372,4572$ 


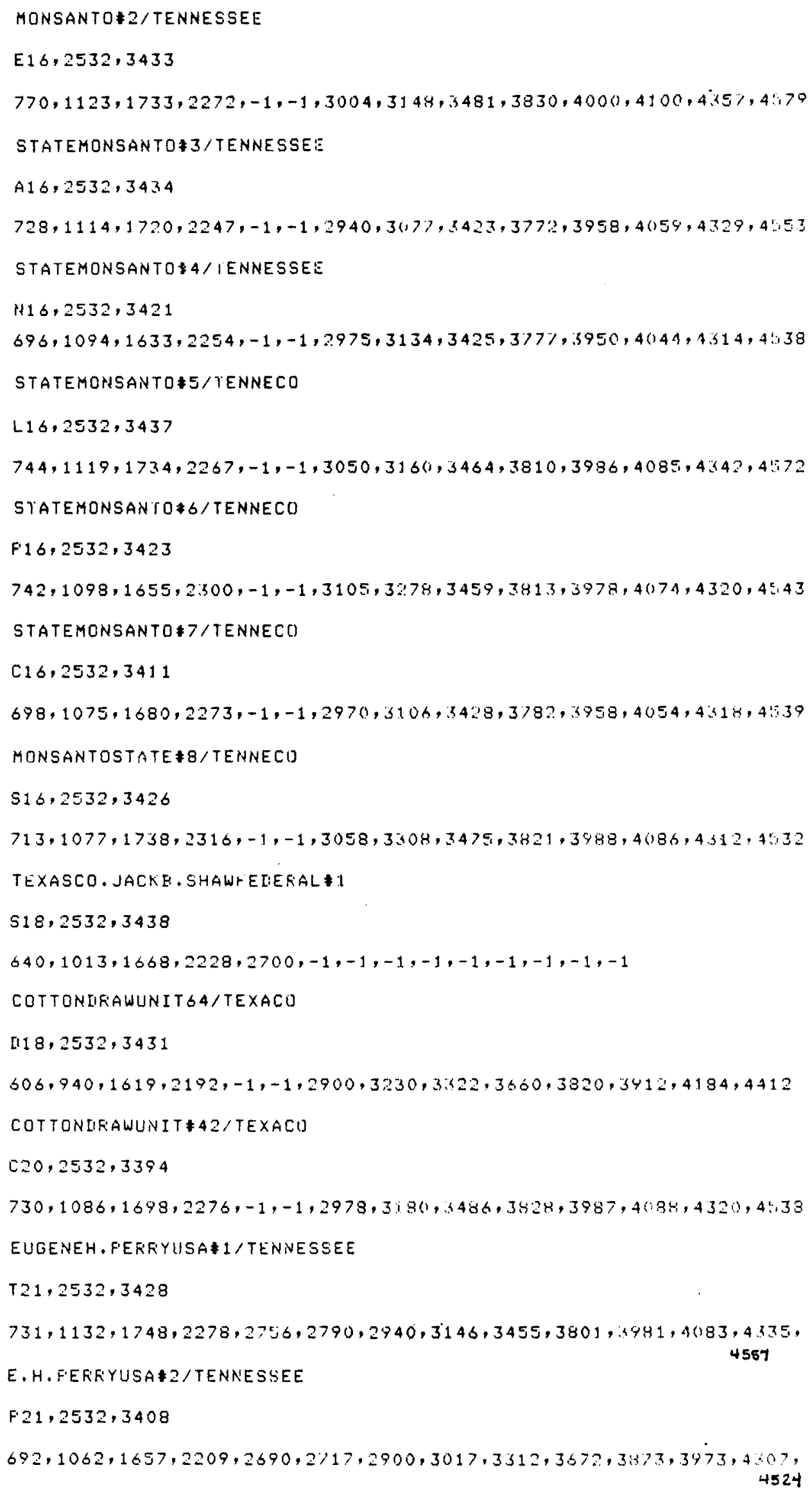


\$3E.H,FERRYUSA/TENNESSEE

$E 21,2532,3422$

$739,1173,1765,2339,3012,3208,-1,-1,3512,3855,4020,4118,1339,4557$

E.H.FEFRYUSAWELLNOZ /TENNECO

$H 21,2532,3404$

$706,1072,1681,2259,2720,2750,2892,3088,3383,3726,3904,4002,4318$, COTTONEIRAWUNIT44/TEXACO

4540

C $21,2532,3400$

$756,1131,1740,2258,2712,2742,2944,3309,3442,3786,3967,4066,4352$, COTTONDIFAWUNIT\$S7/TEXACO

4577

$[121,2532,-1$

$740,1114,175 i 8,2278,2748,2778,2900,3020,3452,3 / 96,3960,4060,4360$, FERFYFEIIERAL $\$ 1 /$ F'ANTHEFC.ITY

1586

$F 21,2532,3430$

$768,1127,1765,2304,2801,2830,2786,3184,3501,3348,4010,4410,4.349$, FEFEYYFEIIERAL 2 /FANTHERCITY

$521,2532,3421$

$719,1108,1759,2300,-1,-1,2962,3124,3517,3860,4027,4124,4365,4587$ FERTYFELIERAI.NOS/FANTERCITY

$621,2532,3409$

$747,1117,1741,2300,2780,2812,3045,3128,3497,3841,4029,4120,4319$, FEFRYYFEIERALNOG/FANTHERCIIY

4540

$Y 21,2532,3400$

$726,1107,1740,2306,2734,2312,3060,3165,3491,383 \%, 3993,3994,4312$, FEER'YYELIERALNOT/FANTHERE: ITY

4530

$k 21,2532,3415$

$712,1096,1700,2247,-1,-1,2950,3083,3407,3750,3930,4032,4313,4534$ FEFFYYFEDERAL $\$ 27$

$121,2532,3406$

$738,1115,1761,2296,2730,2760,2910,3005,3457,3,94,3983,4083,4,354$, FEREYYEEERAL $28 /$ HANTHERICITY

4578

$821,2532,3413$

$752,1124,1744,2281,2733,2761,2478,3006,3463,3806,3480,4080,4352$,

FEFIYYFEIERAL 3 SIFANTHERICIIY

4874

$121,2532,3384$

$727,1100,1720,2310,-1,-1,2976,3177,3470,3819,3981,4491,4319,4539$ 


\section{FER'F'YFE[IER'AL $\$ 37 /$ F'ANTHER'CITY}

$M 21,2532,3398$

$746,1116,1700,2230,2700,2730,2480,2430,3422,3769,3946,404,7,7$, FERFYYEIIERAL \$SB/FANTHERTITY

4556

$N 21,2532,3404$

$776,1148,1731,2259,2715,2744,2406,3005,3435,3780,3950,4650,4434$, FERFIYFEIERILL $\div 43 / F \cdot$, F. KASS

4552

$\cup 21,2532,3382$

$754,1113,1700,2245,2695,2725,2685,2492,3417,3759,3730,4030,4,428$,
4550 6. E. JORIANFEIIERALNCT - INCIS/TEXACO

$T 22,2532,3421$

$769,1141,1759,2270,-1,-1,2980,3178,3570,3935,4005,4104,4404,4629$

G.E.JOREANFE[IERIALNOJ/TEXACU

$122,2532,-1$

$748,1128,1752,2287,2761,2791,2945,3056,35,29,3870,4038,4132,4465$ COTTONIFAHUNITNUAY/THXACO

$c 22,2532,3411$

$747,1116,1750,2270,2730,2760,2887,301 \% \cdot 4441,687 ., 4402,4102,4,79$. FEIIEFIAL $\cdot F \cdot N O 1,1 / 1,1$, U UENEIILL

$023 \cdot 2532,3429$

$748,1084,1896,2430,2890,2920,3185,3294,3032,3767,: 50,454,454$, GE JORIIANFE[ITERLOA\%TEXACOS

4731

$625,2532,3430$

$772,1156,1768,2295,-1,-1,2933,3139,3468,3816,3987,4094,4402,4,29$ AEHMOMZHILLIATIHEILFALNU1-2S

A.25, 2532, 3332

$1043,1390,2270,2855,-1,-1,3558,3900,4005,4363,4550,465,40,970$ COTTONLIRAWUNITINO61\%TEXACO

$627,2532,3391$

$756,1130,1770,2300,2957,-1,-1,3040,3504,3446,4016,4,118,4685,440 ?$ JIISENAUSA $1 \%$ TENNECO

$J 28,2532,3375$

$899,1258,1834,2341,-1,-1,2850,2941,3443,3789,3956,405,4446,4560$ JIISENAJK . USA $2 \%$ TENNECO

$[128,2532,3370$

$957,1332,1920,2548,-1,-1,2851,2461,3437,3726,3946,4045,4341,4561$ 
COTTONLFAWUNIT $\$ 4$. $\%$ TEXACOS

$\mathrm{C} 28,2532,3382$

$817,1173,1755,2275,-1,-1,283,2974,3407,3750,3925,4025,4: 29,495$

COTTONDRAWUNI I $14 \%$ KIEXACO

$428,2532,3392$

$784,1168,1745,2270,-1,-1,2900,2450,3447,3789,3463,407,, 4346,4168$ COTTONIRALUUIT $\$ \%$ TEXACO\%

$\mathrm{T} 28,2532,3412$

$868,1225,1798,2306,-9,-1,2858,2455,3445,3783,3956,4054,4434,4559$ COTTONIRAWUNIT $\$ 51 \%$ TEXACO\%

$\times 28,2532,3398$

$780,1140,1750,2270,-1,-1,2890,3011,3463,3807,4070,4083,4340,4: 35$ COTTONIREAWUNIT $\$ 56 \% I E \times A C O$

$N 28,2532,3388$

$738,1118,1739,2276,-1,-1,287 \div, 3012,3464,3806,3886,3 y 94,4,55,4: 76$ COTTOHIRAWUNITNCI + CjA\%TEXACO

$w 28,2532,3386$

$812,1177,1750,2273,-1,-1,2866,2962,3460,3748,3964,40,2,4350,4568$ DOHONLIFAWUNITNOSES\% 7 EXACO

$228,2532,3386$

$768,1148,1739,2261,-1,-1,28 \% 0,295,3,3470,3810,4028,4124,4365,4484$ CONOLOFEIIEFAL $11-29 Z \mathrm{~J}$. W. L.OVELALYY

$[29,2532,3366$

$1141,1485,-1,2532,-1,-1,-1,3025,3429,3259,3430,4032,4906,4227$

COTTONLFA WUNTTSB/TEXACO

$T 29,2532,3356$

$922,1305,-1,-1,-1,-1,2853,2995,3402,3742,3917,4019,4330,4: 51$

HANKAMEFNO1/COIT RINENTALFEIEFAL.

$H 31,2532,3551$

$862,1208,2026,2492,3070,3114,-1,-1,3123,3762,3951,4050,435,4.488$ FAYSMITH $\$ 1$

$531,2532,3311$

$1075,1420,1980,2485,2725,2785,-1,-1,3290,3626,3773,3800,4135,4350$ WESTATESFET . CDOFTX, JENNINGS $\$ 1$

$w 33,2532,3349$

$930,1307,1825,2375,3040,3060,-1,-1,3520,3840,4000,4105,4349,45,70$ 


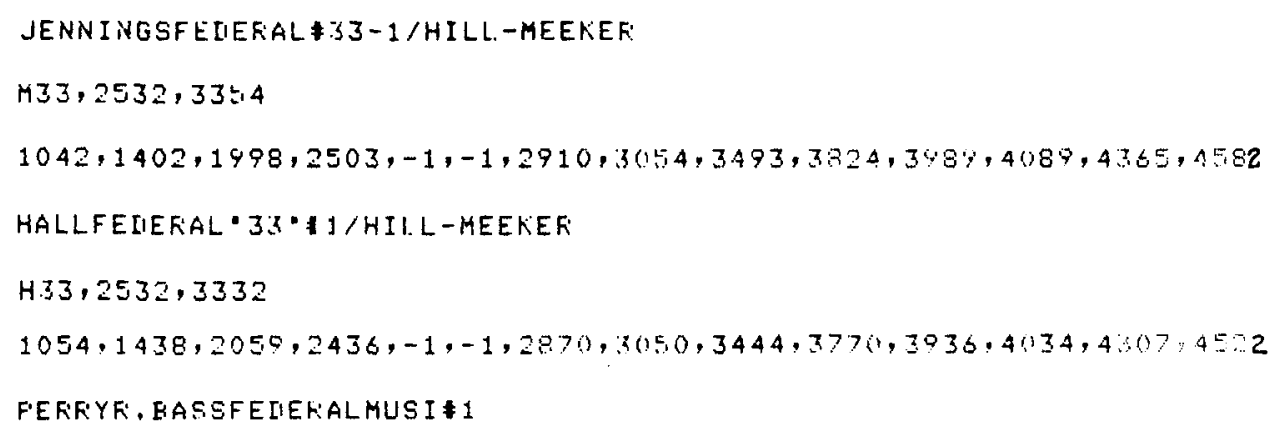

A.21,2533,3392

$1006,1332,2295,2940,-1,-1,-1,-1,-1,-1,-1,-1,-1,-1$

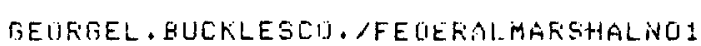

$521,2533,-1$

$1038,1382,2260,2838,3312,3330,3690,3733,3832,404,433,4,440,1,10$, TEXACOCO/COTTLINJFALWUATTNOI8

$T 22,2533,3414$

$1046,1123,1760,2300,2835,2870,3013,3240,3651,3886,404,4,50,4400$, HILL\&MEEKEF/MUSEFFELIERAL $23 \neq 1$

4638

$M 23,2533,3353$

$1060,1400,2260,2811,3323,3350,3550,3,90,3479,4248,4106.4470,4557$ 
R. B. FARKISFE.RRYFE.IIL.KIAL

$F 24,2.533,3359$

$1044,1460,2355,2947,3394,342,4,-1,1,3563,4330,4533,4642,4676,6,25$

KINGRESOUFICESFANAMERICANFEDERALMO.1

K.5. 2533,3343

$1043,1440,2298,2850,-1,3300,-1,3848,3947,4320,4485,4577,4571,5119$ ROEERTA , IIEANHAFFYYIICKSON\$1

$[127, ? 533,3320$

$1020,1382,2230,2780,-1, \cdot 1,-1,3735,3830,4190,4350,4460,4755,4595$

TILIEWATEROLLCO/ANIIEK, BASSFEIHEFAL $\$ 1$

$T 28,2533,3353$

$970,1308,2140,2700,3285,-1,3300,3669,3752,4096,4255,4558,4656,4095$ TENNECUOILCU,W.H. JHNNINGSINC. USA 1

$T 29,2533,342 \%$

$992,1381,2245,2756,3380,-1,3425,3778,3854,4180,4295,4,75,4562,490 \%$

TERNESSEEGASTRANSMISSIORFICHAKISONSBASSUSA 1

$731,2533,3386$

$738,1096,1915,2490,3000,3034,3190,3250,3743,4003,4232,4.30,40,6$, REILH.WILLSCONTINENTALSTATENO.1

4810

$W 32,2533,3391$

$900,1208,2088,2650,3140,3170,3285,3540,3775,4100,4456,4350,461 \ldots$, FUREOII.COHFANYREIHILLSURIT $T$ 1

4886

$1132,2533.3332$

$873,1195,2045,2678,-1,-1,-1,-1,-1,-1,-1,-1,-1,-1$

ASHMONHILLIARIOII_CO.STATEN1-36

$A 36,2533,3346$

$1035,1423,2291,2859,3480,-1,4504,3886,3982,4350,4115,4622,4575,512$

MAXKI D ILSONMAEATHONSTATH 1

$W 36,2533,3325$

$963,1332,2222,2775,3272,3304,3447,3650,4010,4360,4436 \cdot 4040,4560$, 
DISTRIBUTION:

DOE/TIC-4500, R74, UC-70 (316)

US Department of Energy, Headquarters (3)

Office of Nuclear Waste Management

Attn: Program Manager (WIPP)

Director, Division of Waste Isolation (2)

Washington, DC 20545

US Department of Energy, Headquarters

Office of Defense Waste and By-Products

Attn: Director

Washington, DC 20545

US Department of Energy (2)

Albuquerque Operations

Attn: W. R. Cooper, Mgr, WIPP, Project Office (2)

PO Box 3090

Carlsbad, NM 88221

US Department of Energy

c/o Battelle Office of Nuclear Waste Isolation

505 King Ave

Columbus, $\mathrm{OH} 43201$

Battelle Memorial Institute

Office of Nuclear Waste Isolation.

Attn: S. Goldsmith, Mgr, ONWI Library

505 King Avenue

Columbus, OH 43201

Battelle Memorial Institute

Project Management Division

505 King Avenue

Columbus, $\mathrm{OH} 43201$

Bechtel National, Inc. (2)

Attn: D. L. Ledbetter

D. Roberts

Fifty Beale St

PO Box 3965

San Francisco, CA 94119

Stanford University

Department of Geology

Attn: K. B. Krauskopf, Chairman

Stanford, CA 94305

Oak Ridge National Laboratory

Attn: J. O. Blomeke

PO Box X

Oak Ridge, TN 37830

US Geological Survey

Water Resources Division

Attn: J. D. Bredehoeft

Western Region Hydrologist

345 Middlefield Rd

Menlo Park, CA 94025

Karl P. Cohen, Consultant

928 N California Ave

Palo Alto, CA 94303

Fred M. Ernsberger, Consultant

1325 NW 10th Ave

Gainesville, FL 32605

Johns Hopkins University

Department of Earth Sciences

Attn: H. P. Eugster

Baltimore, MD 21218

University of New Mexico

Department of Geology

Attn: R. C. Ewing

Albuquerque, NM 87131

University of Minnesota

Department of Civil and Mineral Engineering

Attn: C. Fairhurst

Minneapolis, MN 55455

University of Texas

Department of Geological Sciences

Attn: W. R. Muehlberger

Austin, TX 78712

Vanderbilt University

Department of Environmental Engineering

Attn: F. L. Parker

108 New Engineering Building

Nashville, TN 37235

D'Arcy A. Shock, Consultant

233 Virginia

Ponca City, OK 74601

WIPP Public Reading Room

Attn: G. Schreiner

Atomic Museum, KAFB East

Albuquerque, NM 87185 
DISTRIBUTION (Cont):

Carlsbad Municipal Library

WIPP Public Reading Room

Attn: L. Hubbard, Head Librarian

101 S. Hallagueno St

Carlsbad, NM 88220

Thomas Brannigan Library

Attn: D. Dresp, Head Librarian

106 W Hadley St

Las Cruces, NM 88001

Roswell Public Library

Attn: N. Langston

301 N Pennsylvania Ave

Roswell, NM 88201

Hobbs Public Library

Attn: M. Lewis, Librarian

509 N Ship St

Hobbs, NM 88248

State of New Mexico (2)

Environmental Evaluation Group

Attn: R. H. Neill, Director

320 Marcy St

PO Box 968

Santa Fe, NM 87503

NM Department of Energy and Minerals (2)

Attn: L. Kehoe, Secretary

K. LaPlante, Librarian

PO Box 2770

Sante Fe, NM 87501

Emery C. Arnold

New Mexico State Geologist

PO Box 2860

Sante Fe, NM 87501

New Mexico State Library

Attn: I. Vollenhofer

PO Box 1629

Sante Fe, NM 87503

New Mexico Tech

Martin Speer Memorial Library

Campus St

Socorro, NM 87801
University of New Mexico

Zimmerman Library

Attn: Z. Vivian

Albuquerque, NM 87131

USGS, Water Resources Division (2)

505 Marquette, NW

Western Bank Bldg, \#720

Albuquerque, NM 87102

USGS, Conservation Division

Attn: W. Melton

PO Box 1857

Roswell, NM 88201

USGS, Special Projects Branch (2)

Attn: R. P. Snyder

Federal Center, Bldg 25

Denver, CO 80225

NM Bureau of Mines and Mineral Resources (2)

Attn: F. E. Kottlowski, Director

Socorro, NM 87801

Klaus Kuhn

Gesellschaft fuer Strahlen-und

Umweltforschung MBH Muenchen

Institut fuer Tieflagerung

Berliner Strausse 2

3392 Clausthal-Zellerfeld

FEDERAL REPUBLIC OF GERMANY

Klause Eckart Maass

Hahn-Meitner-Institut fuer Kernforschung

Glienicker Strasse 100

1000 Berlin 39

FEDERAL REPUBLIC OF GERMANY

Michael Langer

Bundesanstalt fuer Geowissenschaften und Rohstoffe

Posfach 510153

3000 Hanover 51

FEDERAL REPUBLIC OF GERMANY

Helmut Rothemeyer

Physikalisch-Tèchnische Bundesanstalt

Bundesalle 100

3300 Braunschweig

FEDERAL REPUBLIC OF GERMANY 


\section{DISTRIBUTION (Cont):}

Rolf-Peter Randl

Bundesmisterium fuer Forschung und Technologie

Postfach 200706

5300 Bonn 2

FEDERAL REPUBLIC OF GERMANY

Fenix \& Scisson, Inc.

Attn: J. A. Cross

3170 W Sahara Avenue

Spanish Oaks D-12

Las Vegas, NV 89102

Gayle Pawloski, L-222

Geologist CSDP

Lawrence Livermore Laboratory

Livermore, CA 94550

US Nuclear Regulatory Commission (3)

Division of Waste Management

Mail Stop 69755

Attn: J. Martin

M. Bell

H. Miller

Washington, DC 20555

Center of Waste Management Programs

Department of Social Sciences

Attn: G. L. Downey

Michigan Technology University

Houghton, MI 49931
Department of Geological Sciences

Attn: D. W. Powers

University of Texas at El Paso

El Paso, TX 79968

UCLA

Department of Earth and Space Sciences

Attn: J. Rosenfeld

Los Angeles, CA 90024

University of Texas

Department of Geological Sciences

Attn: J. K. Warren, Ph.D.

Assistant Professor

PO Box 7909

Austin, TX 78712

6000 E. H. Beckner

6253 J. C. Lorenz

6330 W. D. Weart

6331 D. J. Borns (11)

6331 S. J. Lambert

6331 A. R. Lappin

6331 K. L. Robinson

6331 S. E. Shaffer

6331 C. L. Stein

6332 Sandia WIPP Central Files (12)

7111 L. J. Barrows

7133 R. D. Statler

7135 P. D. Seward

8024 M. A. Pound

3141 C. M. Ostrander (5)

3151 W. L. Garner (3) 